\title{
Andrzoj Gassiorowski
}

\section{HEADQUARTERS \\ OF THE DEFENDERS \\ OF POLAND [KOP] THE POMERANIAN DISTRIGT DIVISION}

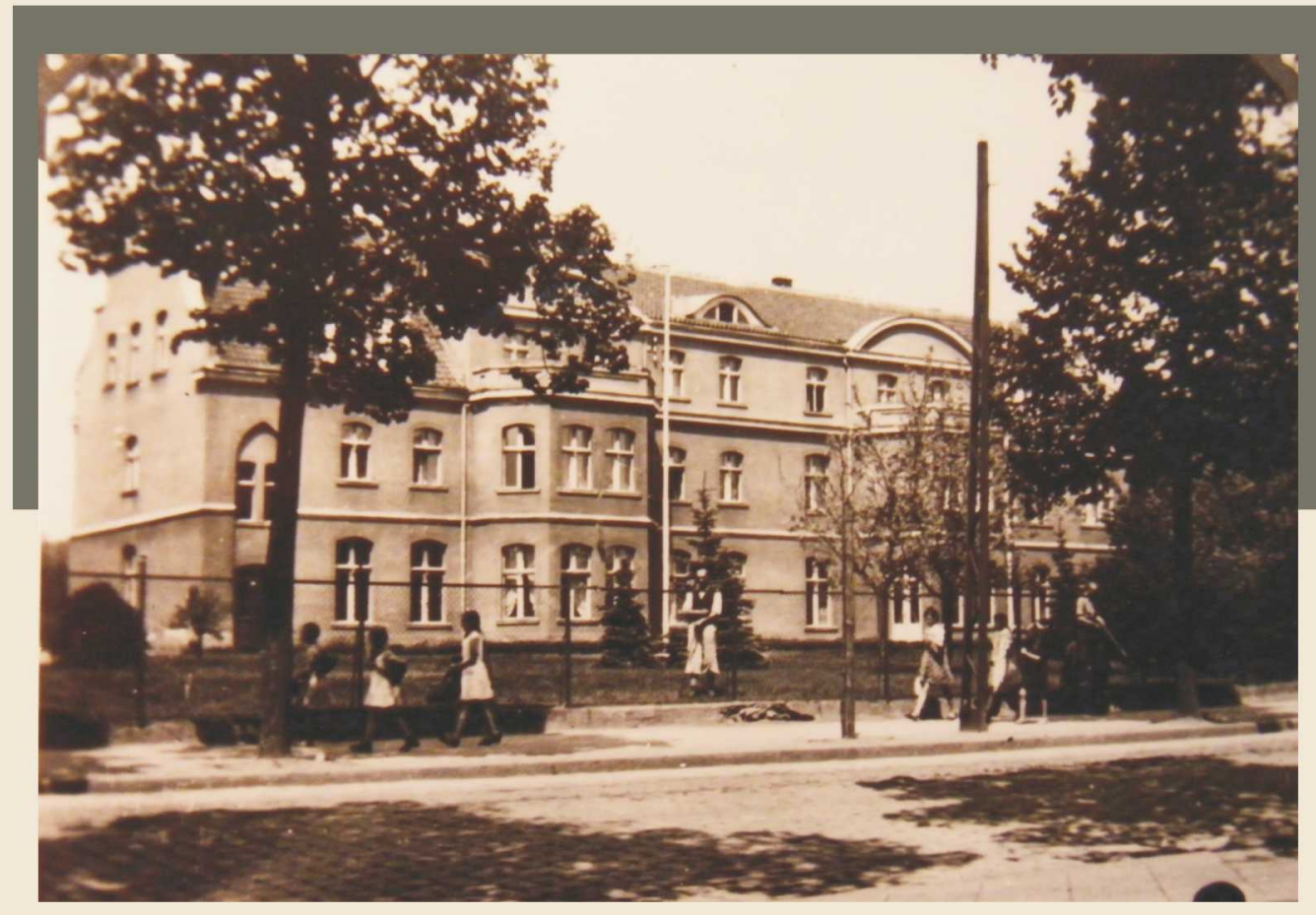


HEADQUARTERS OF THE DEFENDERS

OF POLAND (KOP)

THE POMERANIAN DISTRICT DIVISION 
The Library of the Foundation

"Pomeranian Archive of the Home Army"

in Toruń

Volume LXIV

The Editorial Board of the Library

Head

ANDRZEJ TOMCZAK

Members

BOGDAN CHRZANOWSKI, SYLWIA GROCHOWINA

JAN SZILING

Secretary

KATARZYNA MINCZYKOWSKA

\section{UARODOWY PROGRAM ROZWOJU HUMANISTYKI}

Financed as part of the contract 676/P-DUN/2016

From the resources of the Ministry of Science and Higher Education devoted to the activity of popularizing science 
ANDRZEJ GĄSIOROWSKI

\title{
THE HEADQUARTERS \\ OF THE DEFENDERS OF POLAND \\ THE POMERANIAN DISTRICT DIVISION
}

\author{
TRANSLATED BY \\ AGNIESZKA CHABROS
}

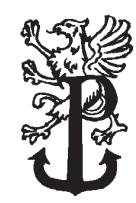

Foundation of General Elżbieta Zawacka

Toruń 2016 
Publications for the Foundation of General Elżbieta Zawacka are reviewed by:

prof. dr hab. Grzegorz Berendt, prof. dr hab. Józef Borzyszkowski, prof. dr hab. Bogdan Chrzanowski, prof. dr hab. Mirosław Golon, dr hab. Sylwia Grochowina, prof. dr hab. Włodzimierz Jastrzębski, prof. dr hab. Jarosław Kłaczkow, prof. dr hab. Waldemar Rezmer, prof. dr hab. Stanisław Salmonowicz and prof. dr hab. Jan Sziling

Design of the cover

ZUZANNA FILARSKA

Main editor

KATARZYNA MINCZYKOWSKA

Markup and corrections

ANETA DĄBROWSKA-KORZUS

Indices

BARTOSZ DRZEWIECKI

Printed in Poland

Foundation of General Elżbieta Zawacka

Pomeranian Archive and Museum of the Home Army and the Military Service of Women

Toruń 2016

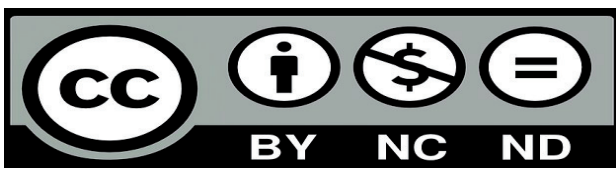

ISBN 978-83-88693-71-7

http://dx.doi.org/10.30747/LXIV.71.7 


\section{LIST OF CONTENTS}

INTRODUCTION

Chapter I. GENERAL CHARACTERISTICS OF THE HEADQUARTERS OF THE DEFENDERS OF POLAND (origin - aims - structure - activity)

1. About the origin and beginnings of the Headquarters of the Defenders of Poland (KOP)

2. Aims of the Headquarters of the Defenders of Poland (KOP) 23

3. The Main Headquarters of KOP 30

4. The territorial structure 37

5. The work of the intelligence service pillar .......................................................... 47

6. Propaganda and information policy ….................................................................. 49

Chapter II. POMERANIAN DISTRICT OF THE HEADQUARTERS OF THE DEFENDERS OF POLAND (the development of the organization and structure)

1. The role of Piątkowski and Odrowski in the creation of the Pomeranian District Division of KOP

2. The appointment for the position of the commander of the Pomeranian District Division of KOP

3. The structures of KOP in Torun 66

4. The structures of KOP in other Pomeranian towns 76

Chapter III. THE MAIN ACTIVITY SPHERES OF THE POMERANIAN DISTRICT DIVISION OF THE HEADQUARTERS OF THE DEFENDERS OF POLAND

1. Contacts in Warsaw 84

2. The intelligence activities of the Pomeranian District Division of KOP 89

3. The propaganda and information activities of the Pomeranian District Division of KOP

Chapter IV. THE GESTAPO'S ACTION OF ELIMINATION AND INVESTIGATION

1. The first arrests

2. The betrayal of the KOP District Headquarters liaison Władysław Jędrzejewski 106

3. Arrests of the members of KOP in Warsaw 110

4. The investigation by the Gestapo in Warsaw and Grudziądz and further arrests 114

5. Accounts of the investigation process in Grudziądz 120

6. Arrests in Włocławek 122

CONCLUSION 127

BIBLIOGRAPHY 131

PERSONAL INDEX 142

INDEX OF GEOGRAPHICAL NAMES 150 



\section{INTRODUCTION}

It was Professor General Elżbieta Zawacka, code-name "Zo", who persuaded me to write a book about the Pomeranian District of the Headquarters of the Defenders of Poland (KOP). She rightfully believed that those who had laid the foundations of the underground activity in Pomerania in the early autumn of 1939 deserved this. I gave my word to write the book, but the plans I had made earlier delayed writing it. There were also other reasons for the delay. I hoped that the monograph of the Headquarters of the Defenders of Poland (KOP) would come out and it would be easier for me to write about one of its districts, having acquired the complete knowledge about the organization. However, I waited in vain. Many a time has the organization of The Headquarters of the Defenders of Poland been written about, but nobody has presented the complete activity of this incredibly interesting underground organization.

The first - very laconic - information about the Headquarters of the Defenders of Poland were published in London in the work Polish Armed Forces in WWII in the third volume devoted to the Home Army, in the chapter More important military organizations, their descriptions and attitude towards the Home Army where the Polish People's Army was discussed. Having described briefly the organization of the Committee of the Defense of Poland or the Committee of the Defenders of Poland, the author wrote that after the heads of KOP had been shattered by the Germans in January 1941: "The military commander of KOP was assisted by the Union of Armed Struggle (ZWZ) and succeeded in protecting some part of the military units against being broken apart, mainly in Warsaw. This part of KOP was incorporated into ZWZ at the end of 1941. However, some radical factions of the groups survived; the later fought against the Home Army and cooperated with the Polish People's Army. There existed data that made 
the heads of the Home Army suppose provocative actions were undertaken in those remaining parts of KOP" 1 .

Originally, at home most information was included in the "Military Historical Review" issued by the Military Historical Institute. In 1966 the study by Tadeusz Tarnogrodzki and Ryszard Tryc titled Polish Underground Organizations at Home was included there, where basic information about $\mathrm{KOP}^{2}$ was provided. Dr Czesław Jaworski, code-name "Sas", started the polemics with some of the statements included in the study ${ }^{3}$.

In 1967 in the "Military Historical Review" the article by Michat Wisniewski From the history of the creation and activity of the Headquarters of the Defenders of Poland ${ }^{4}$ appeared. It continues to constitute the most thorough study about KOP. In the introduction Wisniewski stated that the organization of KOP deserves being discussed for several reasons. He indicated that it was one of the first underground organizations - it commenced its activity at the end of September and the beginning of October 1939. The author stressed that the heads of KOP were closely connected not so much with the Polish government in exile as with General Władysław Sikorski, and presented a negative attitude towards the Union of Armed Struggle (ZWZ and their concepts $^{5}$. The article of over thirty pages was based on a relatively rich source base consisting of documents and materials collected in the Military Historical Institute in Warsaw. Wisniewski completed the sources with oral accounts provided by a few former members of KOP.

After the article by Wiśniewski had appeared in the "Military Historical Review", polemical letters sent to the editorial boards were published in the journal. The officer of the Main Headquarters of the Union of Armed Struggle - the Home Army (ZWZ-AK) colonel Jan

${ }^{1}$ Ibid., pp. 162-163.

2 T. Tarnogrodzki, R. Tryc, Polskie organizacje konspiracyjne w kraju, Wojskowy Przegląd Historyczny, 1966, nr 4.

${ }^{3}$ C. W. Jaworski ps. "Dr Sas", O działalności organizacji "Polska Niepodległa” w czasie okupacji hitlerowskiej, Wojskowy Przegląd Historyczny, 1968, nr 1, pp. 427-429.

${ }^{4}$ M. Wiśniewski, $Z$ historii powstania i działalności Komendy Obrońców Polski, Wojskowy Przegląd Historyczny, 1967, nr 3, pp. 224-256.

${ }^{5}$ Ibid. 
Rzepecki took a stand on KOP. In two letters Rzepecki expressed his criticism towards some of the statements included in the article by M. Wisniewski and the information included in the materials collected by Henryk Borucki'.

Henryk Borucki argued with the theses included in the first letter by Rzepecki in the "Military Historical Review" concentrating on two aspects: the circumstances of the creation of KOP and the propaganda activity conducted by this organization?

In his letter to the editorial board of the "Military Historical Review" a retired colonel Kazimierz Pluta-Czachowski wrote in the introduction: "As the author invited the readers to contribute with their remarks and comments, I am encouraged to put forward the following rectifications". Pluta-Czachowski sent to the "Military Historical Review" numerous pieces of information about KOP, which complemented the knowledge about the beginnings of the organization and its firstcommander-in-chiefmajor Bolesław Studziński, code-name "Bohdan Nitecki".

Later, again in the "Military Historical Review", there appeared a letter by Zygmunt Malanowski, code-name "Prus", "Turkus" - during the occupation he held the position of inspector and the head of the Main Headquarters of KOP. He rectified the mistakes included in the article by M. Wiśniewski, which concerned the personnel composition and the structure of KOP along with issues connected with shattering KOP and its associations with other organizations ${ }^{10}$.

Another publication about KOP was an article by Jan Mulak Komenda Obrońców Polski (KOP) na wzór POW, which came out in

6 J. Rzepecki, O działalności organizacji “Komenda Obrońców Polski”, Wojskowy Przegląd Historyczny 1967, nr 4, pp. 463-464; idem, Jeszcze o organizacji KOP, Wojskowy Przegląd Historyczny, 1969, nr 1, pp. 461-466.

${ }^{7} \mathrm{H}$. Borucki alias "Czarny", O powstaniu i działalności propagandowej KOP, Wojskowy Przegląd Historyczny, 1968, nr 4, pp. 376-380.

${ }^{8}$ K. Pluta-Czachowski, W sprawie konspiracyjnej organizacji "Komenda Obrońców Polski”, Wojskowy Przegląd Historyczny, 1968, nr 3, p. 463.

${ }^{9}$ Ibid., pp. 463-466.

${ }^{10}$ Z. Malanowski alias "Prus", “Turkus”, Jeszcze raz w sprawie KOP, Wojskowy Przegląd Historyczny, 1971, nr 1, pp. 411-413. 
$1988^{11}$. It deserves our attention as Jan Mulak during the occupation headed the Workers' Militia of the Polish Socialists' Party - an underground formation of military nature, which in 1943 was incorporated in the Polish People's Party created on the basis of KOP. In his article Mulak included an incredibly interesting piece of information about the origin of $\mathrm{KOP}^{12}$.

Another person mentioning KOP is Maria Turlejska, who writes about the organization in her book Spór o Polskę. Szkice historyczne. In her work she included the general description of KOP. In Encyklopedia II wojny światowej published in 1975, there appeared the entry: Komenda Obrońców Polski, KOP. The organization was discussed in a way which was typical of the publications of the Ministry of National Defence at that time - as "Polish underground organization of bourgeois-democratic nature, set up at the end of September and the beginning of October 1939; connected with the policy represented by General W. Sikorski; presenting a negative attitude towards the Sanation regime blamed for Poland's being defeated in September 1939". It included basic information about the entourage from which the majority of members of KOP came, the range of its activity in the occupied state, Hungary and Romania.

Subsequently, the information about KOP was to be found in many studies of various nature. For example, Jerzy Janusz Terej wrote about KOP in his work Na rozstajach dróg. Ze studio nad obliczem i modelem Armii Krajowej, the first edition of which came out in 1978. Wolfgang Jacobmeyer mentioned KOP in his work devoted to the original period of the Polish underground during WWII ${ }^{13}$. Piotr Matusak in his work about the resistance movement in Poland mentions KOP vaguely referring to it only in the part concerning local underground actions. Besides, when writing about the creation of the Polish Peo-

${ }^{11}$ J. Mulak, Komenda Obrońców Polski (KOP) na wzór POW, Dzieje Najnowsze, 1988, nr 1, pp. 170-198.

${ }^{12}$ Ibid., p. 173.

${ }^{13}$ W. Jacobmeyer, Heimat und Exil. Die Anfänge der polnischen Untergrundbewegung im Zweiten Weltkrieg, Hamburg 1973, pp. 369. 
ple's Party he cursorily states that it was set up as "part of the People's Militia of the Workers' Party of Polish Socialists"14.

Jerzy Ślaski in his six-volume work Polska Walczaca (1939-1945) addresses the issues of KOP very cursorily stating that the order of General Wlilhelm Orlik-Rücken was issued upon the organization "the name of which could be abbreviated as KOP. Upon this order a big and vibrant organization: the Headquarters of the Defenders of Poland was set up... [...] KOP was an extensive organization, embracing the whole country, having its branches in Hungary and Romania. It ran military, sabotage-subversion, intelligence activities; it dealt with the transfer of people abroad; it also issued a few papers"15.

Konrad Ciechanowski was the first to write about KOP in Pomerania in 1972 in his research work devoted to the Pomerania underground movement. He shortly discussed the activity of KOP in Chapter IV Poczatki ruchu oporu na Pomorzu Gdańskim ${ }^{16}$. Other scholars who cursorily wrote about KOP were W. Jastrzębski and J. Sziling in their work concerning the German occupation in Pomerelia ${ }^{17}$. More information about the original period of functioning of the Pomeranian Distrcit of KOP is to be found in the works about the origin and beginnings of the Pomeranian underground of WWII ${ }^{18}$. Next, KOP was mentioned in the publications by T. Jaszowski, who concentrated on the circumstances of KOP being shattered by the Gestapo in Pomerania and the problem of the function of KOP in Torun ${ }^{19}$. The most detailed text about the Pomeranian District Division of KOP was included in the work devoted to the Polish Underground State in

${ }^{14}$ P. Matusak, Ruch oporu w Polsce 1939-1945, Katowice 1987, pp. 44, 168.

${ }^{15}$ J. Ślaski, Polska Walcząca (1939-1945), t. 1, Warszawa 1999, p. 231.

${ }^{16}$ K. Ciechanowski, Ruch oporu na Pomorzu Gdańskim 1939-1945, Warszawa 1972, pp. 87-93.

${ }^{17}$ W. Jastrzębski, J. Sziling, Okupacja hitlerowska na Pomorzu Gdańskim 1939-1945, Gdańsk 1979, p. 283.

${ }^{18}$ A. Gąsiorowski, Geneza i początki ruchu oporu na Pomorzu Gdańskim, Gdańsk 1991, pp. 75--92.

19 T. Jaszowski, Gestapo w walce z ruchem oporu nad Wisła i Brda, Bydgoszcz 1985, pp. 53-54, 80, 101; idem, Okręg Pomorski Armii Krajowej. Podokręg południowo-wschodni, Toruń 1996, pp. 34-35, 67, 69, 81-82. 
Pomerania in the years $1939-1945^{20}$. B. Ziółkowski also wrote about the activity of KOP in Włocławek in his several publication ${ }^{21}$.

The basic issue is the source base concerning KOP. Various documents from the occupation period have survived. Some of them were created as organizational documents of KOP. Others are known only as copies or translations into German by the Gestapo. Much interesting but hard to verify data about KOP were found in the postwar investigation materials. They remained inaccessible for researchers for many years. Most information was to be found in the investigations protocols, which on the one hand constitute the mine of knowledge about KOP and other organizations maintaining contacts with KOP; on the other hand, they include much false information. The verification of the information included in the sources is very hard.

The key figure in reference to the source about KOP is undoubtedly the second commander-in-chief Henryk Borucki, code-name "Czarny". His testimonies done after his being arrested by the Gestapo and the testimonies provided during the prolonged investigation conducted by the Ministry of Public Security in Warsaw, particularly his long dissertations, constitute the mine of knowledge about KOP. Still, they are a challenge for scholars since the specific personality and political temperament of Borucki cause that the materials and documents generated by him should be treated with a certain distance.

The fundamental issue is the credibility of the accounts about KOP. The plethora of sources generated in a relatively long time creates serious difficulties for scholars. It may be stated that if sources concerning the underground activity are a real challenge for historians, then various preserved accounts about KOP constitute an incredible challenge for historians who for many years have conducted research on the Polish underground movement in the years 1939-1945.

${ }^{20}$ B. Chrzanowski, A. Gąsiorowski, K. Steyer, Polska Podziemna na Pomorzu w latach 1939-1945, Warszawa 2005, pp. 229-249.

${ }^{21}$ M.in. B. Ziółkowski, Kształtowanie się ruchu oporu we Włocławku - Komenda Obrońców Polski, Życie Włocławka, 2002, nr 77; idem, Kujawski Związek Polityczno-Literacki i Kujawskie Stowarzyszenie Społeczno-Literackie na Kujawach Wschodnich w latach okupacji hitlerowskiej 1939-1945, Toruń 2006, pp. 96-100. 
It must be underlined that there exist accounts about KOP from the central level, along with organizational documents - sometimes only their copies - generated by KOP. However, sources for the Pomeranian District Division of KOP are of a distinct nature. As there are no documents of the Pomeranian District Division of KOP, all the issues connected with this district were examined on the basis of various accounts, most of which were created after the war. The documents which had survived the war play an auxiliary role in presenting the problems of the Pomeranian District Division. During the research the scholars managed to reach very valuable accounts showing the hitherto unknown events and episodes from the activity of $\mathrm{KOP}$ in Pomerania and referring to the investigation carried out by the Gestapo in Grudziądz against KOP. I succeeded in revealing the hitherto unknown sources, the use of which enabled me to present the most important issues connected with the work of the Pomeranian District Division of KOP in a broader manner.

$$
* * *
$$

Reading the book may not be easy. Apart from the basic text in many places I cite various sources as this is the only way to provide the reader with the opportunity to get familiar with the original sources. It will enable the reader to understand that it is extremely difficult for a scholar to spot traps in them and it will allow the reader to get closer to the ambience of the period.

To conclude, I would like to express my hope that the book which Professor General Elżbieta Zawacka did not manage to read will cause that all those who were the first to launch the underground activity in Pomerania will find their place in social memory. Although they were not active for a long period of time, many of them sacrificed their lives so that Poland could be independent again. It is worth remembering about. This is what Professor General Elżbieta Zawacka expected. 


\section{GENERAL CHARACTERISTICS OF THE HEADQUARTERS OF THE DEFENDERS OF POLAND (origin - aims - structure - activity)}

1. About the origin and beginnings of the Headquarters of the Defenders of Poland (KOP)

As far as the origin and the beginnings of the body of KOP are concerned, it must be noted that there exist two versions about them. The information about this problem may be found both in German documents of 1941 and postwar accounts and publications. Undoubtedly, KOP, which formerly had used the name the Defenders of Poland, was set up by professional officers doing their military service as commanders of elitist formations of the Border Protection Corps dispersed along the eastern border of Poland. In many postwar publications it was Major Bolesław Studziński who was considered to be the creator of the underground organization KOP. However, from other sources it is known that the initiative to establish such an organization was also put forward by General Orlik- Rückeman. There is also another version concerning the origin of KOP and its founders. This problem deserves a more thorough analysis.

It is worth quoting the words of Colonel Kazimierz Pluta-Czachowski not only because he held important positions in the Union of Armed Struggle - the Home Army (ZWZ-AK)22 and possessed

${ }^{22}$ Kazimierz Pluta-Czachowski, false surnames: Kazimierz Borkowski, Władysław Rusinek alias "Gołdyn", "Kuczaba”, "Paprzyca”, oficer of the permanent infantry service of the Polish, sub-colonel (1939), colonel (1943). In 1939 co-founder of the Organization 
much information about the general organization of the Polish underground movement. It seems that what was much more relevant was his prewar involvement in the military activity to prepare teams of people ready to commence the underground activity in the Polish territories occupied by the enemy Another important aspect were his associations with Major Bolesław Studziński ${ }^{23}$. As he wrote in 1968: "I have known Major Bolesław Studziński, the founder of the underground organization KOP, for many years. Prior to WWI we were both involved in secret scouting. During WWI we served in Brigade I of the Legions, and later we held similar posts in adjacent districts of POW. Major Studziński was the commander of the "flying units" of the Pomeranian Military District (POW), the organizer of the famous "eks" action for the Austrian train near Garbatka in 1918. During the war of 1920 we served in the Operation Group 'Mozyrz' commanded by General Władysław Sikorski. In sovereign Poland we frequently cooperated in the ventures promoting sport and military training, in the Union of Legionaries and the Union of POW. Until the outbreak of the war in 1939 Studziński was a member of the central authorities and won the popularity and trust of the members of the organization. In 1936 we met again in the headquarters of KOP, and he was working in the section of physical education and military training as practiced by KOP. Our work overlapped and we complemented each other, so cooperation was close. Moreover, we had been friends for years. I knew Major Studziński very well and I can describe him best. In the headquarters of KOP we were subordinated to the first deputy of the commander of KOP - General Wilhelm Orlik-Rückeman (who was also a legionary)" ${ }^{24}$.

White Eagle, after uniting OOB with ZWZ - the commander of the IV Territory of Cracow-Silesia ZWZ. In the summer of 1941 he took on the position of the head of the Division $\mathrm{V}$ and deputy head of the Staff of the Main Headqaurters of the Union of Armed Struggle - the Home Army [KG ZWZ-AK]. See his biogram: A. K. Kunert, Słownik biograficzny konspiracji warszawskiej 1939-1944, t. 1, Warszawa 1987, pp. 129-131.

${ }^{23}$ See: K. Pluta-Czachowski, Organizacja Orła Białego. Zarys genezy, organizacji $i$ działalności, Warszawa 1987, pp. 38-46.

${ }^{24}$ Idem, W sprawie konspiracyjnej organizacji "Komenda Obrońców Polski”, Wojskowy Przegląd Historyczny 1968, nr 3, p. 463. 
Pluta-Czachowski learnt about the circumstances in which the underground organization KOP had been set up from General Wilhelm Orlik-Rückeman and Major Bolesław Studziński in Warsaw on 10 October 1939. Thus, it is worth quoting more extensive fragments of his account on this subject, since it is the only postwar account of an eye-witness. Describing the beginnings of the underground organization KOP and Major Studziński’s involvement into the underground movement, he stated that on 30 September 1939 General Orlik-Rückeman in Włodawa dissolved the group of KOP that he commanded taking into consideration the political, operational and tactical conditions. He decided that the struggle should take place in the underground. So, he chose Major Studziński - the fighter of the former POW and the officer who had both underground and military-social experience. Studziński was one of Piłsudskis associates as was General Orlik-Rückeman, who ordered him to set up the underground organization based in Warsaw, which would mobilize and inspire the nation to resist the enemy. Major Studziński received an order that the name of the secret organization refer to the abbreviation KOP. He received from General Orlik-Rückeman stamps of the headquarters of KOP, which were to legitimize him and indicate the political-military activity of the organization and its background. Moreover, he received the financial resources of $1,500,000$ zlotys. The money was to finance the help to the families of former officers of KOP. There was a plan to use contract workers of KOP and part of the wealth and equipment from the publishing department and the cultural-educational section of KOP (machines and printing equipment). It was the rich equipment that allowed Studziński to launch the organizational-underground activity, particularly in the form of press. He went from Włodawa to Warsaw through his family town - Lublin. It was in Lublin that he created the first organizational branch of KOP consisting of former members of POW, legionaries and activists of the Polish Riflemen's Association. Studziński reached Warsaw on 4 or 5 September 1939 and met General Orlik-Rückeman launching the creation of the organization and the mobilization action. He took on the codename "Bogdan Nitecki", which he used as the commander-in-chief of the Headquarters of the Defenders of Poland. It was the name and 
surname of one of his colleagues who had been killed in 1915 in the Legions $^{25}$. On 10 October 1939 in Warsaw there was a meeting of General Orlik-Rückeman, Major Studziński and Colonel Pluta-Czachowski, who had returned from Cracow, where he had taken part in establishing the Organization of the White Eagle (OOB) incorporated into the Service for the Victory of Poland ${ }^{26}$. Three officers met on 12 October 1939 in order to discuss important problems. General OrlikRückeman stated then that he had finished his activity at home and intended to go abroad. According to Colonel Pluta-Czachowski, he agreed with Major Studzinski the details of the cooperation between $\mathrm{KOP}$ and the Organization of the White Eagle (OOB). He provided him with all the contact points in the already existing districts of the OOB, where the paper of KOP Polska Żyje, published since 10 October 1939, was sent ${ }^{27}$.

According to Colonel Pluta-Czachowski, the underground organization KOP created by General Orlik-Rückeman and Major Studziński from about 12 September 1939 was commanded by the latter who was its commander-in-chief. Major Studziński was too experienced a conspirator to take on the name of the military formation particularly hated by one of the enemies - the Soviets. He changed the name of the organization which he had taken on for emotional reasons into Komenda Obrońców Polski - the Headquarters of the Defenders of Poland. In order to cover the background of the organization the names the Organization of the Defenders of Poland and the Defenders of Poland were used.

${ }^{25}$ According to Pluta-Czachowski, the head of the counter-intelligence of the Border Protection Corps also bore the same surname.

${ }^{26}$ Colonel Pluta-Czachowski desrcibed this moment differently in the book about the Organization of the White Eagle. He wrote:” 'Gołdyn' [the code name of Pluta-Czachowski - A.G.] managed to get (thanks to Warsaw's members of KOP) to the hideout of General Orlik- Rückeman. He was the superior of 'Gołdyn'. The general received the report about the launching of the underground movement of $\mathrm{OOB}$ and organizational rules and forms; he stated that he also had ordered to set up the military underground organization - KOP, major Studziński being its main organizer in the region of Włodawa" See: Pluta-Czachowski, Organizacja Orła..., p. 95.

${ }^{27} \mathrm{~K}$. Pluta-Czachowski presented this moment somewhat more extensively in his book about the Organization of the White Eagle. K. Pluta-Czachowski, Organizacja Orła..., pp. 96-97. 
The author of another version of the origin of the Headquarters of the Defenders of Poland is Jan Mulak ${ }^{28}$. According to him, in the spring of 1939 Sub-Colonel Adam Borkiewicz ${ }^{29}$, the former fighter of POW from his own initiative prepared and sent to the General Inspectorate of the Military Forces the project of setting up an underground organization in case Poland lost the $\mathrm{war}^{30}$. It was to be used depending on the development of the military situation at home. SubColonel Borkiewicz planned to establish powerful organizational centres along important communication tracks to Warsaw from Gdynia, Katowice, Lviv, Poznan and Vilnius. The emphasis was to be given to the development of the organization in the west part of the country. According to Borkiewicz's project, the creators of the local branches sent from Warsaw were to return immediately after they had established contacts. In order to provide the maximum security to the underground body Borkiewicz planned that they should start an activity later on, but on the territory prepared by somebody else. Much significance was attached to the communication inside the new organi-

${ }^{28}$ Jan Mulak (1914-2005), a sportsman before the war connected with the Polish Socialist Party; he acted in the so called Socialist Action. During the occupation, he quickly got involved in the underground activity. Originally, he was the head of the Military Division of the group "Barykada Wolności" [the Barricade of Liberty], next he was the deputy commander of the militant formation of Polish Socialists; after the Workers' Party of Polish Socialists was set up in April 1943 he became the head of the Military Division and the secretary of the Central Committee of the party; he took part in the Warsaw Uprising.

${ }^{29}$ Adam Borkiewicz (1896-1958), acted in POW from August 1914, in the "lotny" unit, next he was the commander of the District of Konin and Koło. From 1918 to 1939 he held various positions in the Polish Army(from 1935 sub-colonel), in 1935 he was the commander of the battalion KOP "Suwałki". From June 1938 he was the secretary general of the Association of POW's members [POW - the Polish Military Organization]. During the war of 1939 he took part in the defence of Lviv, next in the camp in Hungary, from where he escaped in the autumn of 1941 and came back to Warsaw. He got involved into the activity of ZWZ-AK, from November 1942 he was the commander of the Sub-District of the Eastern Territory Warsaw AK, from the beginning of 1943 the deputy of the Main Inspector of WSOP. He took part in the Warsaw Uprising; later he continued his underground activity. On 1 Jan 1945 he was given the rank of colonel. After the war he was a historian specializing in the Military Studies, the author of the first monograph devoted to the Warsaw Uprising published in 1957.

${ }^{30}$ A. K. Kunert, Słownik biograficzny..., cz. 1, p. 47, he writes:” In the spring of 1939 from his own initiative he prepared and sent to GISZ the draft of the underground organization in case Poland lost the war with the Germans" 
zation. It was to be dual-track - connected with the headquarters 1) radially, and 2) crosswise - between various local centres (creating circular lines) $)^{31}$.

According to Jan Mulak, Sub-Colonel Borkiewicz suggested employing former members of POW as they had the necessary experience in the underground activity ${ }^{32}$. It is hard to state how credible the information provided by Mulak is that in August 1939 the supreme military authorities ${ }^{33}$ appointed three people to start work on the creation of the above-mentioned organization. The three people were: Sub-Colonel Adam Borkiewicz, Major Bolesław Studziński and a reserve officer whose name remains unknown. According to Mulak, prior to the mobilization they managed to prepare the general organizational rules and send the first emissaries. Further work was interrupted by the mobilization as members of the headquarters received their former tasks which differed from the new ones ${ }^{34}$.

Pluta-Czachowski, when discussing the political image of KOP - wrote the following about his last contact with Major Studziński: "I met Major Studziński for the second and last time in January 1940 in Lublin, where I went for family reasons. I found him sick and bedridden. Discussing current issues, we touched upon the decision of the government which ordered the centralization of military organizations at home into one political-military body named the Union of Armed Struggle (ZWZ) having removed from it all the leading associates of Piłsudski. Major Studziński, who was a fervent associate of Piłsudski, declared that in such conditions he was prohibited from entering the ZWZ. For logistic reasons he approves of the superior-

${ }^{31}$ J. Mulak, Komenda Obrońców Polski (KOP) na wzór POW, Dzieje Najnowsze, 1988, nr 1, p. 173.

${ }^{32}$ It is hard to establish now whether Sub-Colonel Borkiewicz taking over the function of the secretary general of the Association of POW's members should be associated with those prewar preparations and whether Borkiewicz had got involved in the abovementioned project earlier than Jan Mulak supposed. It is known that 1935 Sub-Colonel Borkiewicz was the battalion KOP "Suwałki”. See: A. K. Kunert, Słownik biograficzny..., cz. 1, p. 47.

${ }^{33}$ Mulak did not provide any details.

${ }^{34}$ J. Mulak, Komenda Obrońców..., p. 173. Jan Mulak maintained contact with KOP, particularly in the years 1943-1944. 
ity of the government over the country, but he was determined to act independently until the discriminatory order was withdrawn" ${ }^{35}$.

Major Studziński died in Lublin in April 1940. He had suffered from tuberculosis for a long time, for which reason he had been withdrawn from the border service before the war. His death terminated the first period of the existence of KOP. He died when KOP was looking for its place within the structure of the Polish Underground State, and had to decide whether to become closely connected with the ZWZ upon the centralization process or to become involved into the work of the Conciliation Committee of the Independence Movements (Komitet Porozumiewawczy Organizacji Niepodległościowych - KPON), which included a few military or political and military organizations. It seems that after the death of Studziński there took place the first visible turnabout and since then KOP had played the role of the body which initiated the processes of forming the political-military centre which competed with the Home Army.

The second commander-in-chief of KOP was Henryk Borucki, code-name "Czarny"36, who in his postwar account wrote very cursorily about the fact of being appointed to this position. Borucki wrote: "In April Major Studziński dies - the first Commander-in-Chief of KOP. The convention of the Chief Board, the Main Headquarters as delegates of all the districts appoints me to hold the position of the commander-in-chief of $\mathrm{KOP}^{37}$. It must be noted that we failed to establish in what way Borucki - who stayed at that time in Warsaw - succeeded in taking over all the contacts of Major Studziński, who had died in Lublin, along with all the organizational heritage of KOP. It is one of the most important moments in the activity of KOP, about which still not much is known.

Borucki's being appointed the commander-in-chief of KOP was essential for the organization to continue working. His political views, life experience and personal connections influenced the development

${ }^{35}$ K. Pluta-Czachowski, W sprawie..., p. 463.

${ }^{36}$ Henryk Borucki (1913-1969), false name: Alfred Rawski. See: his biogram: A. K. Kunert, Słownik biograficzny konspiracji warszawskiej, cz. 3, Warszawa 1991, pp. 47-51.

${ }^{37}$ IPN BU, sygn. 0330/246, vol. 2, Relacja H. Boruckiego (without name or date), k. 51. 
of the organization and its political image. Before Borucki joined KOP, he had run the organization Gwardia Ludowa [People's Guards - GW], which he had set up together with several activists of the Polish Socialist Party. It is hard to establish the size of his contribution into the creation of the Gwardia Ludowa as the only accessible account is the one provided by Borucki. He prepared the account after the war when he was imprisoned by the Ministry of Public Security, which must have influenced its content. Describing the circumstances of taking up the underground activity at the beginning of the German occupation, he stated: "October-December 1939 [...] Myself with a numerous group of acquaintances, friends, co-workers from the prewar period and a number of companions from the September Campaign- we all reached the conclusion: Rydz with his clique is not an army, and the Sanation is not the Nation. Poland will continue to exist until her People, until ourselves are determined and able to fight against the enemy and to live free. While forming the organizational frameworks of one of the first Polish resistance groups thanks to Tadeusza Hartleba (one of the former editors of Robotnik) I got in touch Stanisław Dubois, who was involved in an activity similar to mine. We understood each other in no time - our achievements complemented each other. (...) In this way, the organization to which we gave a brave name Gwardia Ludowa was set up. I became the commander while Dubois dealt with the political and propaganda issues, making much effort to restore and redevelop the Polish Socialist Party (PPS). The programme of Gwardia Ludowa was short and clear: inexorable struggle using all possible means and manners with the barbaric fascist enemy so that each Pole was a soldier, and each square metre of the Polish land became the front for Hitler. Having learnt from our tragic history, we want to build a truly democratic state after Poland's victory - People's Poland. Poland without the Sanation clique, without capitalist hyenas, without landowners, rogues and capitalist exploiters"38.

We know the circumstances in which Borucki got familiar with KOP only from his accounts. He described them very cursorily, failing to provide names of the people thanks to whom he had got in

${ }^{38}$ IPN BU, sygn. 0330/246, t. 2, Relacja Boruckiego (without name), k. 45. 
touch with KOP. Apart from this, he concentrated on presenting the political image of KOP, underlining the anti-Sanation attitude of Studziński, which is not confirmed by other sources. The contacts between General Sikorski and KOP provided by Borucki should be treated with a certain distance. However, it is worth quoting his account as it shows the manner in which in a relatively short period of time Borucki won the position in KOP, which allowed him to take over the position of the commander-in-chief after the death of Major Studziński and to give the organization the anti-Sanation orientation. Borucki mentioned this using a specific language which was characteristic for all the texts written by him: "At the end of October 1939 the Gwardia Ludowa was incorporated into the Warsaw District of KOP. I was appointed the commander of this district. [...] In December the Warsaw District of KOP became the pillar of the whole organization, assisting all other districts and doing all the work belonging to the Main Headquarters. With time Major Studziński, feeling unwell, devotes his time mainly to the work associated with the publication of Polska Żyje, to running the financial department of the organization and foreign contacts of the Main Headquarters of KOP. On 19 December General Sikorski sends us the "Organizational Instruction of KOP" approved of by himself, the first part of money (so far we have used the funds from the September campaign which were the property of the Border Protection Corps and other military units) and a number of orders. I, keeping my position of the commander of the Warsaw District, am promoted to the rank of captain and receive the rights of inspector of all the remaining districts" ${ }^{\prime 3}$.

Colonel Janusz Albrecht, code-name "Wojciech" - the head of the Staff of the Main Headquarters of the Union of Armed Struggle, familiar with bigger secret military organizations - in his testimonies of July 1941 describes KOP in the following way: a) KOP: KOP is one of the first military organizations. It includes relatively few officers, but quite a few sub-officers. Their officers are predominantly of lower ranks; their main superior is a major I do not know. The task of our unit I or II is to maintain loose contacts with those organizations.

${ }^{39}$ IPN BU, sygn. 0330/246, t. 2, Relacja Boruckiego (without name), k. 46. 
The Section of Press and Propaganda maintains contacts with purely political organizations. KOP issues an illegal paper Polska Żyje. Their main seat is Warsaw" ${ }^{\prime 4}$.

\section{Aims of the Headquarters of the Defenders of Poland (KOP)}

The aims of the Headquarters of the Defenders of Poland (KOP) - originally known as the Defenders of Poland - were relatively quickly formulated. As early as 1 October 1939 the Regulations to the instruction of the Defenders of Poland were prepared. The document said that the basic aim of the organization is "the military and spiritual preparation of the nation to the struggle with the enemy" ${ }^{1}$. It was underlined the Polish government created in France was considered legal and that the organization subjected itself to the superiority of the Commander-in-chief Gen. Władysław Sikorski ${ }^{42}$.

Each member admitted to the organization had to take the following vow: "Becoming a member of 'Defenders of Poland' I swear to God and Motherland that I execute the orders of the organizational authorities willingly and without hesitation; that I keep all the secrets of the organization that I swear not to give away even when forced to do so; that I serve to make Motherland sovereign until the final victory. So help me God". The person who listened to the vow proceeded with saying the following words: "Colleague! I confirm that you have become a member of 'the Defenders of Poland'. You have just taken the vow. Should you break the vow, you will have to face great responsibility before the organizational authorities, and even greater responsibility before God"43.

The ceremony of taking the vow assumed that the person listening to the vow shook the hand of a new member and kissed them. Having taken the vow, a new member received their identification sign. Later a new member was given two member cards: a black one and a red one. The first served to prove their identity to the organi-

${ }^{40}$ L. Dobroszycki, Sprawa płk. dypl. Janusza Albrechta $w$ świetle źródeł niemieckich, Wojskowy Przegląd Historyczny, 1960, nr 1, pp. 295, 308.

${ }^{41}$ M. Wiśniewski, Z historii..., p. 225.

${ }^{42}$ Ibid.

${ }^{43}$ Ibid. 
zational authorities, whilst the other was to be hidden and used only after Poland regained its sovereignty being shown to the appropriate state authorities ${ }^{44}$. However, soon it was decided that the member cards could become the evidence against the organization's members causing their being exposed, so the decision was made to stop issuing them for safety reasons. For the same reason, it was decided that no list of members be kept ${ }^{45}$.

In the first period of its activity KOP did not define clearly its standpoint concerning the most important political matters. The consequence of this was the fact that political viewpoints of KOP received different kinds of criticism. For example, in one of its first publications the organization avoided taking a stand on the reasons of the September defeat and criticizing people responsible for the national defence. In the current propaganda no critical attitude towards the political camp ruling in Poland after 1926 was formulated. Basically, the organization limited itself to fighting the moods of doubts and apathy, so common at the beginning of the occupation, and to maintain the patriotic feelings and the belief in Poland's regaining independence. Such a situation caused that as compared with other underground organization, which continued to express their critical attitude towards the prewar authorities, KOP started to be accused of pro-Sanation sympathies and representing the political interests of this political formation ${ }^{46}$. The heads of the organization decided that it was not possible to continue the policy of not expressing their views on the above-mentioned matters. The fact of incorporating KOP into various circles which evinced clear anti-Sanation political views might have determined this decision. Unsurprisingly, in the January edition of the KOP newsletter Polska Żyje of 1940 an article was published in which KOP distanced itself from the Sanation. It was strengthened by the fact of publishing the manifesto of the Polish government of December 1939 in Polska Żyje in January 1940"77. Publishing the mani-

\footnotetext{
${ }^{44}$ See: Instrukcja organizacyjna of 2.10.1939 r.

${ }^{45}$ M. Wiśniewski, Z historii..., p. 226.

${ }^{46}$ Ibid.

${ }^{47}$ Polska Żyje, 1940, nr 25.
} 
festo should be understood as the approval of all the reforms of the Polish state included in it.

In April 1940 KOP became associated with the Conciliation Committee of the Independence Movements (Komitet Porozumiewawczy Organizacji Niepodległościowych - KPON). However, there are no detailed data about this agreement. There are various accounts concerning the circumstances of the creation of KPON and the organizations it included. All we know is that in April 1940 a few organizations decided to set up a new underground centre subordinated directly to the Polish government in exile. KPON was to play the role of the directive authority. It was thought to take over the competence of the Central Committee of the Independence Organizations $(\mathrm{CKON})^{48}$, which, after the March-April crisis in 1940, had lost its significance. It also resulted from the fact that in the decisions of the Government in Exile of April 1940 concerning the military and political supervision at home CKON was not mentioned ${ }^{49}$.

According to the authors of two accounts: Witold Szklennik and Józef Tyniec taking part in the works of KPON, the organizational meeting of KPON took place on 21 April 1940 in a private flat in Warsaw in Szara street ${ }^{50}$. The date 21 April 1940 is confirmed in the preserved copy of the document. The representatives taking part in the meeting signed the resolution stipulating the aims of KPON. The

${ }^{48}$ The Central Committe of the Independence Movements [CKON], created by Ryszard Swiętochowski in October 1939, the political centre upon the order of Gen. Sikorski. CKON constituted the background for the Political Bureau - the decision-making body. It consisted of the following organizations: Peasants' Organization of Liberty "Racławice", Gwardia Obrony Narodowej, Komendsa Zbrojnego Wyzwolenia, Muszkieterowie [Musketeers], the Military Organization - Kadra Bezpieczeństwa, the Military Organization "Wilki", the SecretPolish Army, Związek Czynu Zbrojnego, Związek Oficerów Rezerwy and the political group Labour Party. CKON was supported financially by General Sikorski. It was a rival body to the PKP and ZWZ. CKON transmitted information to the West about the situation in the Polish underground and was to coordinate the struggle with the occupying forces.

${ }^{49}$ K. Malinowski, Tajna Armia Polska. Znak. Konfederacja Zbrojna. Zarys genezy, organizacja i działalność, Warszawa 1986, p. 105.

${ }^{50}$ It should be noted that $\mathrm{H}$. Borucki in his account gave the wrong date and place of establishing KPON. He wrote: "Although the Committee started operating in February, the first assembly of all the delegates took place as late as March, in Warsaw in Twarda street in the flat of the Rudzki family (I don't remember the number of the house)." 
resolution read: "The Independence Organizations gathered on 21 April 1940 in Warsaw, which acted on the territory of the Rzeczpospolita state unanimously that the September defeat, affecting to the same extent the sentiments and lives of all the strata of the Polish Nation, obliges the whole Nation to continue fighting with the enemies until the final victory and the rebirth of the Rzeczpospolita within its historical borders. To intensify the pro-independence actions all the organizations undersigned consider it the historic necessity and unanimously declare that:

1. Conducting their pro-independence activities they should apply the uniform methods of work and organizational system at all levels of the organization.

2. They should combine the military-organizational, recruitingpreparative, propaganda-informative and financial actions in the Conciliation Committee of the Independence Movements (Komitet Porozumiewawczy Organizacji Niepodległościowych - KPON) considering the Executive Department of this Committee to be the home authority responsible before the Polish Government temporarily based in Angers.

3. They leave the problem of identifying who is guilty for the September defeat to the Tribunal of Reborn Poland and they decide unanimously that they should abandon all the social-political considerations being fully aware of the fact that after the war the authority shall be in the hands of the Polish Nation"51.

The information transferred by Borucki that he was elected the head of KPON has not been confirmed by any sources ${ }^{52}$. According to him, within KPON there were set up permanently the following sections: the Military Section, the Section of Information and Propaganda, the Financial Section and the Interorganizational Court ${ }^{53}$. It

${ }^{51}$ K. Malinowski, op. cit., pp. 105-106. As it can be concluded from fn. 216, the typed copy of this document was kept by Janina Pieńkowska, as part of the TAP Archive and the Armed Confederation.

${ }^{52}$ It seems quite unlikely as members-founders of KPON the Political Bureau to be the future Executive Division - the authority of CKON centred around Ryszard Swiętochowski, to be extended by members of the organizations included by KPON. See: K. Malinowski, op.cit., p. 107.

${ }^{53}$ IPN BU, sygn. 0330/246, t. 2, Relacja H. Boruckiego (bez nazwy i daty), k. 49. 
is also hard to verify the information transferred by Borucki that in the spring of $1940 \mathrm{KOP}$ received form the government the resources of 1 million zlotys and about 200,000 dollars. The money, according to Borucki, was sent to Warsaw by the Consulate of Chile and the receipt was signed by Major Studziński and the treasurer of KG KOP Mieczysław Wieczorkiewicz ${ }^{54}$.

In Borucki' memoirs the events of July of 1940 leading eventually to the collapse of KPON were described more extensively. He presents the problem from the point of view of KOP, which has never been published before. In the part of the memoirs titled Lipiec-wrzesien 1940 [ July-September 1940] Borucki states that in the first days of July 1940 Stanisław Dubois showed the project of the political programme for the Polish Underground prepared by him. He writes: "In the talks and discussions about it apart from me there take part also other people: Major Bończa-Cerklewicz ${ }^{55}$, Colonel Walas, Colonel Królikowski, Captain Brzoza-Daremniak, Dr Wasilewski, Antoni Kordowski, engineer Jaroszyński, Odrowski ${ }^{56}$ and others. The program has been accepted. [...] The organizations such as Grunwald, the Polish Armed Forces, the People's Guard, the Pomeranian Military Organization and other smaller organizations which so far have cooperated with us within the activity of the Committee - are incorporated completely into KOP. We organize within KOP the Department of the Action of Women and we establish the 'Patronage over political prisoners and victims of terror'. Janina Święcicka - a well known member of KOP - is appointed the head of the department. As a result of too big and transparent political differences the organizations of the Military Organization Lizard Union [Związek Jaszczurczy] and Sword and Plough

${ }^{54}$ Ibid.

${ }^{55}$ Cerklewicz Marceli alias “Bończa”, “Juliusz”, “Marian”, "Paszota” (1889-1941), officer of the permanent service, pilot, major/sub-colonel, co-organizer and commander of the underground organization "Grunwald", the head of the militant groups in the KG KOP. See: K. Komorowski, Konspiracja pomorska 1939-1947. Leksykon, Gdańsk 1993, pp. 39-40, 62, 63, 85, 103; A. Gąsiorowski, Geneza i początki ruchu oporu na Pomorzu Gdańskim, Gdańsk 1991, pp. 49, 71, 74, 75, 85, 89.

56 Tadeusz Odrowski alias "Odra", "Pomian”, "Sok" (1891-1957), a farmer, political and cultural-educational activist in Pomerania. See: T. Oracki, Słownik biograficzny Warmii, Mazur i Powiśla XIX i XX wieku (do 1945 roku), Warszawa 1983, pp. 235-236; A. Gąsiorowski, Geneza i początki..., pp. 14, 53-54, 85-86. 
[Miecz i Pług] break off their contacts with the Conciliatory Committee (KPON) and KOP. All this takes place smoothly in a peaceful atmosphere, without any frictions" ${ }^{\prime 57}$. According to Borucki, in July 1940 the Gestapo carried out a raid on the seat of KPON in Warsaw at 5 Oleandów steet in the basement of the department store and transport company located there. It is hard to agree with the opinion of Borucki about this action: "Thanks to the efficient intelligence service the action did not entail any human losses. We only lost the premises well prepared for the underground work" 58 .

According to the post-war information, KPON terminated its activity as early as August $1940^{59}$. It happened not so much due to the above mentioned action by the Gestapo, but as a result of talks conducted from the spring of 1940 among some organizations which were part of KPON, the aim of which was a closer cooperation. It gave rise to a crisis in KPON as not all organizations approved of the project of the creation of the confederation. KOP did not support this initiative and did not enter the Confederation of the Nation set up on 28 September $1940^{60}$, about the creation of which the Government Delegate for Poland and KG ZWZ were informed on 1 November 1940.

Thus, it may be assumed that from September 1940 KOP started to operate independently as part of the Polish Underground. This independence resulted from KOP's dislike towards the Union of Armed Struggle [ZWZ] and other groups which regarded the cooperation with ZWZ as necessary despite being critical about it. KOP maintained the independence until April 1943 although ZWZ-AK had made many attempts to incoporate the military pillar of KOP. The attempts were undertaken on both the central level and in the districts of ZWZ-AK where the structures of KOP operated. The fact of the arrests of the commander-in-chiefof KOP - Borucki (in January 1941 and September 1941) was also used to weaken KOP - he was an ar-

${ }^{57}$ IPN BU, sygn. 0330/246, t. 2, Relacja H. Boruckiego (bez nazwy i daty), k. 52-53.

${ }^{58}$ Ibid., k. 53.

${ }^{59}$ K. Malinowski, op.cit., p. 115.

${ }^{60}$ Ibid., pp. 115-116. See also: Z. Kobylańska, Konfederacja Narodu w Warszawie, Warszawa 1999; K. Krajewski, Uderzeniowe Bataliony Kadrowe 1942-1944, Warszawa 1993. 
dent opponent of uniting KOP with ZWZ-AK. Borucki described the underground activity to reconstruct the independence of KOP after he was released from prison in January 1943: "I looked for the contacts with the groups of the KOP organization the head of which I had been until the day of my arrest on 9 June 1942 - particularly to those which resisted the propaganda and activity of the Sanation centre remaining independent. In this way, within the period of one month and a half I had units consisting of several thousand people at my disposal in Warsaw: the groups of "Mazur" - Tadeusz Włoczkowski, "Pasek" - Edward Włoczkowski, "Wyrwa" - Bronisław Bachliński, "Zygmunt" - Zygmunt Kniaziołucki, "Krzywousty" - Stanisław Antoszewski, "Mściciel” - Roskosz, "Jan" - Jan Krzyżak, "Szeliga" - Janusz Sałaciński, "Góral" - Franciszek Kraszewski, "Turkus" - Zygmunt Malanowski, "Bronek" - Bronisław Kotnowski, "Wir" - I don't remember the surname, "Bóbr" - Edmund Bobrzyk, "Leszek" - Benn Rosner and the group of Malinowski, whose name and codename I forgot. At the same time I selected some operational sub-groups armed with their own weapon or the weapon which had been hidden before the day of me arrest. Originally, there were four such groups, each of them consisting of 12-30 people. Their task was to protect and gain funds. In the meantime I prepared the organization's printing house in Żeran preserved by the group of "Krzywousty" to start working and to recommence the publication of the paper Polska Żyje". [...] In this way I continued the work to make the organization develop" ${ }^{\text {" }}$.

The development of KOP lasted until the spring of 1943 when Borucki - using the political turbulences in the Polish Underground - decided that KOP should play a bigger role. The question that arises here is whether he evinced the political intuition here using the changes in the underground political scene on its left wing connected with the intensified activity of radical socialists [PS] or maybe he became only the executor of the operational idea of the German security police, the aim of which was not only to limit the operational possibilities of the Home Army $[\mathrm{AK}]$, but also to set up the rival decision-making

${ }^{61}$ IPN BU, sygn. 0330/246, t. 4, Protokół przesłuchania H. Boruckiego z 14.12.1949, k. 106-107. 
centre, which was to give Borucki the possibility of the cooperation with the left wing supervised and controlled by the Gestapo. Borucki used this opportunity and KOP became the foundation on which the Polish People's Army - the military formation of the Workers' Party of Polish Socialists [RPPS], later of the Central People's Committee and the Chief People's Committee - was set up.

The Pomeranian District Division of KOP was destroyed by the Gestapo as early as the autumn of 1940; so the subsequent situation of KOP in the Polish Underground and its political image in the years 1941-1943 did not directly affect Pomerania. However, the loss of contact with the Main Headquarters of KOP caused that the structures of KOP operating in Pomerania - originally incorporated into the Polish Army of Resurrection [PAP], and next to the Polish Underground Army ${ }^{62}$ - tried to find their place in the situation of forced isolation, which required them to adapt to new conditions. Supposedly, it was not until the end of 1944 that communication with the central body - now the Polish People's Army [PAL] - was regained and the Pomeranian District Division of PAL was established. The fact of PAL's being connected with the Polish Committee of National Liberation in Lublin, which was subjected to the Soviets and Polish communists, was not revealed to the majority of its members in Pomerania.

\section{The Main Headquarters of KOP}

Major Bolesław Studziński, who originally played the most important role in the organization, in the last days of September 1939 arrived in Lublin. He established the first contacts with the underground - mostly with his friends - former members of the Polish Military Organization [POW] of the years 1915-1918. It was with them that he commenced building the underground organization. It is known that the first meetings took place in the flat of the Wersocki family in Lublin at 48 Bychawska Street. From post-war accounts we know that among the closest co-workers of Studziński there were Reserve Captain of the Polish Army Michał Chrostowski alias "Błysk" - a teacher

\footnotetext{
${ }^{62}$ More about PAP: A. Gąsiorowski, Polska Armia Powstania. Największa tajemnica pomorskiej konspiracji, Torun 1997.
} 
of physics; Sub-Colonel and medical doctor Tadeusz Ejsmont, Franciszek Sitarz and Wincenty Staniszewski alias “Polikowski”. Having arrived in Warsaw Studziński invited many people to the organizational work - e.g. an activist of PPP Henryk Gaudasiński, the head of the literary department of the Polish Radio Witold Hulewicz, a well known socialist activist Janina Święcicka and Ada Tołłoczko-Langmanowa. The underground group People's Guard [Gwardia Ludowa] set up by Henryk Borucki was quickly incorporated into the organization created by Studziński. Its incorporation by KOP took place as a result of the talks conducted by Studziński, Borucki and Wincenty Daremniak. Owing to the incorporation, the following people became mebers of KOP in Warsaw: Tadeusz Hartleb, the commander of the Fire Brigade in Warsaw Gieysztor, Ryszard Szmidt and Roman Wardecki ${ }^{63}$.

Within the organization of KOP known as the Defenders of Poland, executive structures were set up quite quickly. They were created at the turn of September and October 1939. The Chief Headquarters commanded by the commander-in-chiefbecame the head of KOP. The Staff and its head, who according to the instruction of 2 October 1939 was to play a major role in KOP, was subordinated to him. The head of the Staff had the right to decide about inspections in all organizational cells of KOP, but he did not sign all the decrees and orders along with the commander-in-chief. The orders of the Main Headquarters were typed, signed and provided with a stamp known to members of the organization. In practice, the role of the head of the Staff was quite limited. In fact, it was the commander-in-chiefwho took major decisions, issued orders and participated in person in many meetings of various cells of $\mathrm{KOP}$ and other organizations.

The structure of the Main Headquarters underwent frequent changes, but not all of them are reflected in the preserved organizational documents of KOP. In the Main Headquarters of KOP a very important role was played by the Department of Security run by Wincenty Daremniak alias "Brzoza" dealing with both the intelligence service and counterintelligence. This department included also units devoted to protect KOP and subversion units; there were also plans to

${ }^{63}$ M. Wiśniewski, Z historii..., pp. 224-225. 
create the units of the Militia of KOP, which was to provide order and security at the moment of the outbreak of the uprising and the liberation of the country. In the Department of Security there operated a legalization bureau run by Zygmunt Chromiński alias " $Ł u k a s z$ ", who before the war had been an expert in the field employed in Section II of the General Staff of the Polish Army. In the department there was also a prison unit responsible for the contacts with arrested members of KOP. It was headed by Antoni Kordowski alias "Sędzia", "Bydgoski". The main task of this unit was to get in touch with prisoners in Pawiak - the investigation prison of Warsaw's Gestapo. In mid-1940 KOP succeeded in contacting the prisoners in Pawiak. It was possible thanks to the cooperation with some of the Polish prison personnel. Also some of the members of KOP arrested much earlier and playing various functions in this prison helped KOP considerably (e.g. Leon Wanat - a clerk in the main chancery of the prison and a member of $\mathrm{KOP})^{64}$.

In the Main Headquarters of KOP there was probably the Department of Intelligence, but we know very little about its structure and personnel - particularly in the first period of the existence of KOP. According to Borucki, the head of the Intelligence Department was originally Sub-Lieutenant Paweł Piątkowski. In the first general instruction issued by KOP, it said that the aim of KOP was to organize secret intelligence networks all over Poland.

According to Borucki, in February 1940, he replaced Major Studziński, who was very sick, and issued an order to set up the Home Department of KG OP. The head of the department was Stanisław Ludwicki alias "Jarząb", who had experience in the field as the commander of the Łodź district of KOP. His railway network had an extraterritorial character and it included Łódź, East Prussia (the Płock district), Pomerania, the Poznań region, Silesia and some centres in the General Government (Warsaw, Lublin). It was Ludwicki who put forward a project that the Railway Department be established in the Main Headquarters of KOP; it was to plan and coordinate the work

${ }^{64}$ Ibid., p. 244.See also T. Strzembosz, Oddziały szturmowe konspiracyjnej Warszawy 1939-1944, Warszawa 1983, pp. 76-77. 
of KOP within the railway network. It was to be very profitable for the organization. Separate district could create railway units in their territories. Ludwicki ran the Railway Department of KG KOP, being at the same time the commander of the Łódź district of KOP. In April 1940 in Warsaw at 5 Oleandrów Street there took place a briefing devoted to the issues of the railway Department of KG KOP. Ludwicki received contacts with the railway units set up before by individual districts, which operated beyond the Railway Department of KG KOP. Ludwicki was also to discuss the cooperation of the Railway Department with the Departments of Security, Intelligence, Propaganda and other cells of KOP. He transmitted and established proper contacts and organized constant help of the railway cells in the delivery of the organization's press. The name of the department was changed into the Department of Communication and its structure was provided with two additional sections: the car section and the shipping section. Gieysztor and Odrowski were responsible for the organization of the sections. Gieysztor had been previously involved in all car issues being part of the headquarters of the Warsaw district of KOP, while Odrowski - according to Borucki - had had experience in sending shipment from Warsaw to the northern parts of the country using the ship transport on the Vistula river. Stanisław Ludwicki remained the head of the Communication Department marked with the number IV in KG KOP; as he was chased by the Gestapo, he moved from Łódź to Warsaw $^{65}$.

It was not until the first days of September 1940 that the main organizational court of KOP was set up. District courts were set up later. The courts operated on the basis of detailed rules based on the "Polish law adapted to the needs and requirements of the current situation and underground activity" ${ }^{\prime \prime}$.

According to the general instruction of KOP of 2 October 1939 the organization was to be set up in the voivodeships, counties, communes and villages. In fact, it was to include the whole territory of Poland.

${ }^{65}$ IPN BU, sygn. 0330/246, t. 6. Borucki’s testimony titled Organizacja KOP-PAL na terenie kolejnictwa, k. 179-180.

${ }^{66}$ IPN BU, sygn. 0330/246, t. 2, Wspomnienia H. Boruckiego (bez nazwy i daty), k. 54. 
The territorial structure of KOP constituted territorial inspectorates: 1) the inspectorate of Warsaw, 2) the inspectorate of the General Government, 3) the Inspectorate of the Western Lands including also the territories incorporated into the Reich and territories situated before the war beyond the western and northern border of the Polish state, 4) the Inspectorate of Eastern Lands including the areas occupied by the Russians. Officers commanding the above mentioned inspectorates were members of the Main Headquarters of KOP along with heads of individual departments of KG KOP.

In the instruction of KOP organizational functions and ranks were defined irrespective of the earlier military ranks. They were characteristic only for KOP - as many as 23 organizational ranks were distinguished for $\mathrm{KOP}^{67}$. Originally, instructions of $\mathrm{KOP}$ said that all the members were to wear special bands around their arms with their function and ranks in KOP. It was to make it easier to understand who had the right to give orders and who was to execute them, since in the beginning no military ranks had been introduced.

Organizational instructions of KOP ordered the creation of basic militant groups consisting of 10 people (a commander and 9 subordinates). Commanders of the groups had three patrols of 3 people each (the commander of the patrol and two members). Groups were male, female and mixed.

Militant groups were combined in platoons, platoons in companies and companies in battalions. In the organizational instruction no. 2 in part II of the Militant Department it was underlined that the commanders of the militant groups would be county commanders of militant groups. They were subordinated to provincial commanders of militants groups, who were, in turn, subordinated to district commanders. At the level of the Main Headquarters a position of the commander of militants groups was created; he commanded all the

\footnotetext{
${ }^{67}$ Organizational ranks given in various Polish underground organizations or military pillars of undergorund organizations of political nature follwed the military nomenclature. Thus, people who had not previously received any military training, now received officer's ranks. It led to many misunderstandings, particularly when ZWZ-AK incorporated othet organizations, the underground army refused to recognize those ranks.
} 
militant pillars of KOP both in the General Government and the eastern and western teritories ${ }^{68}$.

The female pillar was set up in the structure of KOP. It was the Department of Women's Actions. Its essential task was to prepare women: 1) to do underground social-political work, 2) to do auxiliary military service, 3) to be part of militant female units ${ }^{69}$.

KOP relatively quickly noticed the need to work with the youth. In KOP there was set up a separate cell dealing with the youth. In the autumn of 1940 it was transformed into the Youth Department of KG KOP, the head of which was an architect Aleksy Słonicki alias "Kłoda". With time, appropriate cells dealing with the youth were established in the county, provincial and district headquarters of KOP. They operated on the basis of the instruction provided by the Youth Department of KG KOP. It involved young people of 12-18 years for fear that the young should lose their patriotism and become demoralized. The aim was to organize teaching and inspire young people to self-education. In the period from October 1940 to January 1941 a special paper for the youth was issued Orlęta, the aim of which was to inspire patriotic emotions. It reminded young people of the tradition to fight for the independence of Poland and of the fact that the war would end when the Third Reich was defeated ${ }^{70}$.

From the beginning KOP operated in two pillars: the military one and the civil-political one. Within KOP until mid-1940 there operated in Lublin the Civic-Patriotic Committee supervised by Major Studziński. It was not part of the Main Headquarters of KOP. The task of the Committee was to secure financial resources for the organization and to conduct political and propaganda activities. Thus, Major Studziński ran both the Main Headquarters of KOP and the Civic-Patriotic Committee. After the Main Headquarters of KOP were transferred to Warsaw, the Committee moved to Warsaw as well. Its seat was in a department store at 44 Belwederska Street run by a member of the authorities of KOP Major M. Wieczorkiewicz alias "Sokrates". After the death of Major Studzinski and Henryk Borucki's taking over

${ }^{68}$ AMS, Instrukcja organizacyjna nr 2.

${ }^{69}$ M. Wiśniewski, $Z$ historii..., p. 247. See also Instrukcja organizacyjna nr 2.

${ }^{70}$ Ibid., pp. 238-239. 
the position of the commander-in-chief of KOP, the name and the organization of the work of the committee was changed. The Committee was now called the Auxiliary Military Committee and operated upon the guidelines of the Political and Propaganda Department, which was part of the Main Headquarters of KOP. Financial and economic matters were dealt with by the Economic Department being part of the Main Headquarters of KOP. The next change took place in 1942 when the name was changed into the Committee of Defenders of Poland. In 1943 Borucki founded the Polish Democratic Party on the basis of the Committee of Defenders of Poland ${ }^{71}$.

Henryk Borucki presented the activity of the civil structures of KOP as follows: "From the very beginning in KOP along with the military organization there operated a social body, the main aim of which was to provide the base for the former. I have mentioned many times about the civil dimension of KOP, which originally was represented first by the Civic-Patriotic Committee [PKW], and later by the Auxiliary Military Committee. With time PKW developed into a quite a big organization. There also appeared quite a few cells of KOP conducting civil actions such as social work, self-support, secret teaching, political-propaganda activity, economic activity (promoted by various branches of KG KOP - the political, social, industrial, medical ones, etc.). When it became necessary to coordinate the work of those cells, we decided to combine PKW with all other pillars of the civil activity into one organization. In this way, the concept of setting up the Central Committee of Defenders of Poland and the District and County Committees appeared"72.

Within KOP there operated the so called distinct groups. They were organizations set up before contacts with KOP were established. It is hard to say why some organization incorporated into KOP lost their identity, while others were considered to be distinct. It is known that there were two groups distinguished in KOP: 1) the organization "Odra" operating in Pomerania, Warmia and Mazury, created and run by Tadeusz Odrowski alias "Pomian", "Sok"73, 2) the organization

${ }^{71}$ Ibid., pp. 230-231.

${ }^{72}$ IPN BU, sygn. 0397/60, t. 2, k. 57.

${ }^{73}$ More details provided on subsequent pages of the book. 
"Olga" operating in Silesia, the commander of which was Paweł Ful$\mathrm{Czyk}^{74}$.

There also existed independent groups or units of KOP. They were organizational units established before being incorporated into KOP. They operated on certain territories or in certain entourages being capable of executing more serious tasks; thus, they were given some autonomy within KOP. They had the right to use their earlier names, to recruit new members, to own equipment and even weapons. Commanders of such organizations were subordinated only in exceptional cases to the Main Headquarters of KOP. Normally, they were subordinated to district commanders. Several such groups were established after some earlier cells had become independent within KOP in 1941 after the communication with KOP had been temporarily broken owing to arrests. They were headed by energetic commanders, whose authority was additionally strengthened. After the communication with KOP was restored, they were allowed to maintain a certain degree of independence. Henryk Borucki states that after his return to the position of the commander-in-chiefhe took part in several conferences with the heads of such independent groups ${ }^{75}$.

\section{The territorial structure}

Gradually the territorial structures of KOP were being set up; still, it was not possible to restore the process of the creation of the fundamental structures of KOP on the basis of the preserved accounts. The only thing we know is that in 1940 the organizational-territorial structure was formed; it was in force in the years 1940-1941, in the first stage of the work of KOP.

Four inspectorates were subordinated to the Main Headquarters of KOP. They were divided into districts (with the exception of the Warsaw Inspectorate divided into counties) consisting of counties. Counties consisted of regions, which were later divided into stations constituting the smallest territorial unit of $\mathrm{KOP}^{76}$.

${ }^{74}$ M. Wiśniewski, Z historii..., p. 227.

${ }^{75}$ Ibid., k.137-139.

${ }^{76}$ The structure of KOP differed from the structure of ZWZ-AK. The ZWZ-AK was divided into regions, which were later subdivided into stations. 
The following inspectorates were set up: 1) the Warsaw Inspectorate (including Warsaw, divided into 7 counties), 2) the Inspectorate of the General Government (including the Kielce, Cracow, Lublin and Warsaw districts), 3) the Inspectorate of Eastern Lands with the seat in Warsaw (including eight district: Białystok, Lviv, Nowy Gród, Polesie, Stanisławów, Tarnopol, Vilnius and Volhynia, 4) the Inspectorate of Western Lands with the seat in Kutno and later in Warsaw (including five district: Łódż, Płock, Pomerania, Poznań and Silesia) ${ }^{77}$.

In conclusion, the structure of the organization was primarily adapted to the situation created in the occupied territories of Poland by the occupying forces. It resulted both from varying conditions in different areas (e.g. distinguishing the capital city of Warsaw and the territories occupied by the Germans and the Russians) and difficulties in communication (passing the borders in case of the areas under the Soviet occupation and Polish territories incorporated into the Reich). The territory of the General Government was divided into four districts by the Germans.

At the lowest level the members of individual posts could set up the so called free posts. According to the instruction no. 2 they were to gather trustworthy people who should not know what organization members of KOP belonged to ${ }^{78}$.

Besides, as part of KOP the so called separated groups were established. They maintained their former structure and organizational rules within KOP. Thus, they enriched additionally the structure of $\mathrm{KOP}$, making it more flexible. The biggest groups of this kind were: "Olga" which operated in Silesia and was run by Paweł Fulczyk; "Odra" operating in Pomerania, Warmia and Mazury ${ }^{79}$, which was headed by Reserve Colonel Tadeusz Odrowski alias "Odra", "Sok", "Pomian". It seems that the groups were incorporated into KOP at the beginning of 1940.

It was in the General Government that KOP created its territorial structures. It was also there that they were the strongest. We know that in the Lublin area, where the cells of KOP were created as first, the

${ }^{77}$ M. Wiśniewski, Z historii..., p. 227; Instrukcja organizacyjna nr 2, cz. I.

${ }^{78}$ Ibid.

${ }^{79}$ AMS, Rel. H. Boruckiego. 
structures of KOP were relatively well developed. The Commander of the $1^{\text {st }}$ Region of KOP in the county of Lublin was Antoni Chmieln$\mathrm{icki}^{80}$. At the same time, he had the function of the officer for special orders in the Headquarters of the KOP District in Lublin. When KOP collapsed, he joined the Home Army [AK], continuing to hold the function of the Commander of the Region and the head of the Headquarters of Military Subversion ${ }^{81}$.

In the autumn of 1940 the organizational structures of KOP in Silesia in the Kielce district were developed. In all the KOP districts militant groups were distinguished, which were in a position to start fighting immediately. The remaining members of the organization collected weapons for them. Discussing the development of KOP in this period, the commander-in-chiefof KOP wrote: “The organization includes over 50,000 active officers executing defined tasks, provided with ID cards. The number of reserve members and groups of friends of KOP is several times higher. Members pay premiums. The amount of money KOP receives also enables us to estimate the number of members" 82 .

Not much is known about the activity of KOP in the eastern lands occupied by the Russians. It is quite curious as originally the organization was made up from professional and reserve officers, who were doing their military service in the Border Protection Corps or had done their service in this elitist formation. Particularly important was the role of Major Bolesław Studziński, who had prepared subversion structures as part of the Border Protection Corps. The evidence for this may be his employment in the branch WF and PW in the headquarters of $\mathrm{KOP}^{83}$. Supposedly, he he had some knowledge about sub-

${ }^{80}$ Antoni Chmielnicki, the son of Wincenty and Jadwiga, born on 13 June 1911, Master of Law, did not sere in the army, after 1945 worked in the Polish State Railway [PKP] in Lublin, the controller of the Department of Transport in DOKP in Lublin. In 1950 he was dismissed owing to his hostile attitude to the Polish People's republic. He was employed in ZBW in Lublin. In 1957 he was reemployed in PKP. IPN BU, sygn. 0330/246, t.6.

${ }^{81}$ IPN BU, sygn. 0/330/246, t. 3, Plan operacyjnych przedsięwzięć do sprawy operacyjnego rozpracowywania o krypt. "Nienawiśćc z 4 X 1962, k. 113.

${ }^{82}$ IPN BU, sygn. 0330/246, t. 2, Wspomnienia H. Boruckiego (bez nazwy i daty), k. 56.

${ }^{83}$ In various structures of WF and PW there operated officers dealing with the preparation of teams of the subversion beyond the frontline. More: A. Gąsiorowski, Struktury ter- 
version structures set up before the war in the eastern provinces of the Rzeczpospolita. It is hard to say whether Major Studziński managed to put at least some of the structures into action and incorporate them into KOP. This is what the second commander-in-chiefof KOP testified during the postwar interrogation" I knew that Bolesław Studziński in December 1939 and at the beginning of 1940 made some organizational preparations in the territories occupied by the Soviets, but he failed to complete them because he fell ill and died. When I took over the position of the chief commander, I did not continue such preparations in those territories; nor did I check any of his contacts or establish new ones. In the Soviet area I did not have a single organizational cell, even later when the Germans took over the area. I did not send any person, any instruction, any money and any bullet. I have not crossed the Bug River again ever since" 84 . It was hard to establish the range of the activity of KOP in those territories during the times of the Polish People's Republic. There were only some general statements that in the period from 1939 to 1940 the only cells of KOP had been set up in Vilnius, in Volhynia and in the Lviv province. M. Wisniewski commented briefly that "they did not develop their activity on a larger scale". He concluded: "Like in the subsequent years, after the outbreak of the German-Soviet war and the Germans' taking over eastern territories of Poland, KOP did not show any major signs of activity. The partial extension of the organization in the area did not take place until the years 1943-1944"85. As it may be concluded, it was only then that KOP was converted into the Polish People's Army in April 1943.

Not much information can be found in the preserved documents of the Gestapo concerning the investigation against KOP in the years 1940-1942. It is known that as early as mid-1940 the Main Headquarters of KOP concluded that the Third Reich was planning to start a war against the Soviet Union, so they started to prepare for launching

enowe Państwowego Urzędu WF i PW na Pomorzu w latach 1927-1939 oraz ich rola w przygotowaniu kadr konspiracji zbrojnej, [w:] Organizacje paramilitarne i pokrewne w przededniu II wojny światowej, Toruń 1996, pp. 57-102; M. Starczewski, Wspótpraca członków sieci dywersji pozafrontowej z organizacjami paramilitarnymi i społecznymi w Wolnym Mieście Gdańsku, [w:] Organizacje paramilitarne..., 15-56.

${ }^{84}$ IPN BU, sygn. 0330/246, t. 6, Pismo H. Boruckiego z 9 VII 1953, k. 14.

${ }^{85}$ M. Wiśniewski, Z historii..., p. 228. 
an activity in those territories. KOP selected and appointed people who in the case of the German-Russian war were to be sent to the areas occupied by the Germans which until 17 September 1939 had been part of the Polish state. They were to launch the underground struggle with the Germans there ${ }^{86}$. It is hard to state to what an extent the work was conducted there since the head of the Inspectorate of the Eastern Territories Colonel Edmund Krzyżanowski alias "Dębno" was arrested by the Gestapo in Warsaw in January 1941. It seems that the preparations did not go beyond the preliminary stage ${ }^{87}$.

Later, probably in view of the difficulties connected with the creation of the structures of KOP in the east further attempts were made to establish the cells of KOP there. Henryk Borucki writes about this in general terms: "There was set up a district of KOP beyond the Bug River, to which all organizational cells operating in the eastern territories, both the already existing and the new ones subversion-sabotage groups, were subordinated. The commander of the new district became "As-Aleksandrowicz" 88 . The only thing we know is that in Lviv a dental surgeon Dr Henryk Zieliński commenced an activity as part of KOP. As it may be concluded from the material of Henryk Borucki - in March 1942 he became the head of the cell of KOP appointed to maintain communication with the Jewish community and the Jewish district in Warsaw ${ }^{89}$.

In a relatively short time KOP set up its structures in the western areas of Poland incorporated into the Reich. After Pomerania, northern Masovia, Greater Poland and Silesia had been incorporated into the Reich, the police border between those territories and the General Government was set up. It hindered considerably the communication between the Main Headquarters of KOP in Warsaw and the structures

${ }^{86}$ The order of 24 August 1940 captured by the Gestapo and translated into German. WIH MiD, mikrofilm 433. See: M. Wiśniewski, Z historii..., p. 245.

${ }^{87}$ The evidence for this may be the information fromBorucki that the manuscript captured by the Gestapo, prepared by Sub-Colonel Krzyżanowski, which was the draft of the instructions concerning the underground activity in the eastern territories, had never been rewritten and had never become the valid instruction of KOP. See: . IPN BU, sygn. 0330/246, t. 6, Pismo H. Boruckiego z 9 VII 1953, k. 12.

${ }^{88}$ IPN BU, sygn. 0397/60, t. 3, k. 68.

${ }^{89}$ Ibid., k. 110. 
of KOP operating as part of the Inspectorate of the Western Territories. The circumstances associated with the creation of the structures of KOP in Silesia have not been examined yet.

The territorial structure of KOP in the western territories in the first stage of its activity looked as follows: the Inspectorate of the Western territories was established for the area, the head of which was the inspector, his deputy and the head of propaganda. The units of the Inspectorate scattered in the area created the districts of KOP. There were five such districts: 1) Płock - the town and the vicinities, 2) Łódź - the city and the vicinities, 3) Upper Silesia, 4) Poznan - the city and the vicinities, 5) Pomerania. Each district had its own headquarters consisting of 1 ) the commander of the district, 2) the deputy commander, 3) the organizational unit, 4) the district head of militant groups and the military unit, 5) the district head of propaganda, 6) the unit for the security of the district, 7) the head of propaganda in the district, 8) the female head of women's groups, 9) the head of male youth, 10) the organizational district court. County headquarters were subordinated to district commanders. They consisted of: 1) the commander of the county, 2) the deputy commander of the county, 3) the organizational unit, 4) the head of militant groups, 5) the head of the recruitment office, 6) the unit for the registration of soldiers, 7) the commander of the militia, 8) the county head of propaganda, 9) training for women, 10) training for male youth. County commanders supervised the regions created in communes and stations ${ }^{90}$.

Separate districts of KOP had a distinct territorial range. The Pomeranian District Division of KOP included: Pomerelia, part of East Prussia and Kuyavia ${ }^{91}$. It was planned to set up 30 sub-districts further divided into regions and posts and the so called Free Posts of the Defenders of Poland. However, the incredibly hard conditions in the Pomeranian districts made those plans unrealistic. On the basis of scarce sources it has been established that the organizational network of KOP included the following centres: Bydgoszcz, Chełmno, Chełmża,

${ }^{90}$ IPN W-wa, sygn. Ld 1/200, Sprawozdanie z śledztwa przeciwko polskiej organizacji bojowej “Obrońcy Polski”. Organizacja, zadania, wykazy aresztowanych i skazanych [1941], k. 13-14.

${ }^{91}$ K. Komorowski, Konspiracja pomorska 1939-1947. Leksykon, Gdańsk 1993, s. 86. 
Chojnice, Czernikowo, Gdańsk, Gdynia, Grudziądz, Inowrocław, Kościerzyna, Königsberg [Polish: Królewiec, now Kaliningrad], kwidzyn, Lipno, Rypin, Świecie, Tczew, Toruń and Wabrzeźno ${ }^{92}$. In mid-1940 the reorganization was carried out, the effect of which was the creation of an additional division of the Pomeranian district along the Vistula River into two sub-districts in the north: Gdańsk and East Prussia ${ }^{93}$.

We managed to obtain more information about the creation of the structures of KOP in Pomerania. They appeared quite soon - in October 1939, when the Pomeranian District Division of KOP started to be set up. It was possible as Pomerania had been prepared for subversive activities since 1930. Undoubtedly, some of the groups established before the war were incorporated into KOP. However, the main core of the prewar structures joined the organization Grunwald, which was set up on the basis of the Pomeranian subversive network.

Pomerania was a specific area as far as KOP was concerned. The organization Grunwald became the foundation for the structures of the Pomeranian DistrictDivision of the Union of Armed Struggle [ZWZ]. It was very important as some executive members of the Grunwald organization left Pomerania for Warsaw in the face of the threat of arrest. In Warsaw several most important members of Grunwald refused to join ZWZ establishing contacts with KOP (Major Marceli Cerklewicz, Dr Leon Wasilewski). They played an essential role in the Main Headquarters of KOP. Mutual associations between the organizations - so typical of Pomerania - became later one of the vital reasons for exposure. At present, researchers find it hard to establish the affiliation of some conspirators in Torun conducting their activity in the first stage of the occupation. Owing to a lack of documents and the death of many of them quite a few essential questions remained unanswered. Undoubtedly, the Pomeranian District Division of KOP was the most active in the first stage of the occupation period in the western territories ${ }^{94}$.

\footnotetext{
92 Ibid.

${ }^{93}$ Ibid.

${ }^{94}$ More about the subject matter in the subsequent chapters.
} 
It remains unknown to what an extent the complete organizational structure was set up in all the territorial units which were part of the Inspectorate of the Western Territories of KOP, which makes it hard to discuss the organizational achievements of KOP in Pomerania. It is important as on the basis of available materials one cannot state whether such a complete structure of KOP was created in the Pomeranian district ${ }^{95}$. It seems that the organization encountered significant difficulties and the structure of the Pomeranian District Division of KOP was not complete. This remark does not refer only to the level of the headquarters of the district, but also to lower levels. Undoubtedly, the organizational activity of KOP was the best developed in Torun, which in the first stage of the occupation period became the centre of all more serious conspiracy actions undertaken in Pomerania.

Originally, the Inspectorate of the Western Territories was run by Tadeusz Odrowski alias "Odra", "Sok" ". Later, the position was taken over by Stanisław Ludwicki alias "Ziółkowski", "Jarząb"97. The deputy of the commander of the Inspectorate was Jerzy Moraczewski from Poznań ${ }^{98}$. Unfortunately, it was not possible to establish the date when he took over the office. It is known that he was the deputy of the commander of the Inspectorate in March $1944^{99}$. It is also hard to establish when and in what circumstances he arrived in Warsaw, where he lived in $34 \mathrm{Chmielna}$ Street and worked as an agronomist. He had held the function of the deputy commander of the Inspectorate until he was arrested by the Gestapo in Warsaw on 1 November $1940^{100}$.

${ }^{95}$ Lack of both organizational documents of the Pomerania District of KOP and the information about the documents of the Gestapo.

${ }^{96}$ The author did not manage to establish whether Odrowski had held the function.

${ }^{97}$ K. Ciechanowski, Ruch oporu na Pomorzy Gdańskim w latach 1939-1945, Warszawa 1972, p. 88, he made a mistake establishing that Ludwicki had headed the Inspectorate of the Western Territories of KOP [IZZ KOP ] rom the very beginning. He based his assumtpions on the article by M. Wisniewski, Z historii..., p. 248 and Henryk Borucki's account. According to the documents found in IPN the first head of IZZ KOP was T. Odrowski.

${ }^{98}$ Jerzy Moraczewski born on 26 Sept 1894 in Poznań, an agronomist. See: IPN GK, sygn. 927/2732, t. 1, k. 22, Wywiad z J. Moraczewskim z 12 IX 1970.

99 AMS, Materiały nieuporządkowane; Kopia zaświadczenia J. Moraczewskiego z 24.09.1947 r.

${ }^{100}$ IPN GK, sygn. 927/2732, t. 1, k. 22, Wywiad z 12 IX 1970. 
Another prewar officer Lieutenant Władysław Jaworowski was also probably connected with the Western Inspectorate of $\mathrm{KOP}^{101}$. After leaving Grudziądz in mid-October 1939, he went to Kutno, where he continued hiding using the false name Zygmunt Kamiński. He lived with his wife Danuta Jaworowska in Kutno at 22 Toruńska Street. The beginnings of his activity for KOP remain unknown. In February 1940 Sub-Lieutenant Paweł Piątkowski contacted him and invited Jaworowski and his wife to join KOP. Jaworowski started to create the structures of KOP in the area of Warthegau, which had been incorporated into the Reich. He set up the posts of KOP in Kutno, Konin and Słupca. The towns were situated along an important railway line Poznań-Warsaw. Jaworowski recruited other people to KOP in Kutno, e.g. in May 1940 Jan Gabrynowicz joined the organization ${ }^{102}$. However, nothing is known about Gabrynowicz's function in KOP. The only thing we know is that Jaworowski organized the transfer point of people and underground materials over the border from Kutno-Żychlin to the General Government. The Jaworowskis' flat was the place for couriers and members of KOP under the threat of arrest, where they were put up before setting off to the General Government. Jaworowski and his wife themselves helped them cross the border illegally ${ }^{103}$.

The commander of the Pomeranian District Division of KOP SubLieutenant Paweł Piątkowski, using at that time the false name of Zbigniew Wyleżyński, commenced to recruit new members to KOP in Torun ${ }^{104}$. As early as October and November 1939 he started the creation of the staff of the Pomeranian District Division of KOP. He

${ }^{101}$ Władysław Jaworowski born on 12 August 1912 in Białystok. In the years 1932-1935 in the Artillery Officer Cadet School in Toruń. In the years 1935-1939 he served as sublieutenant in 8PAC in Toruń. On 19 March 1939 he was promoted to the rank of lieutenant. From the spring of 1939 he served in 16 DAc in Grupa in the county of Swiecie. During the war in 1939 fire officer in the 1 Battalion 16 DAC. He fought in the "Pomorze" army in the battle of Kutno. On 24 September he was captured by the Germans. He escaped on 27 September 1939 and reached to Grudziądz, where he remained in hiding until 15 Oct 1939.

${ }^{102}$ Jan Gabrynowicz born in 1892, before the war in the years 1920-1932 a clerk in the Tax Office in Grudziądz, in the years 1932-1939 in the Tax Office in Toruń. In September 1939 he left Torun and settled down in Kutno. AMS, Informacja W. Jaworowskiego z 6 V 2002 r.

${ }^{103}$ AMS, Życiorys W. Jaworowskiego.

${ }^{104}$ AMS, Kol. K. C., Rel. A. Szewy. 
appointed Marian Tuszewski his deputy, who was responsible for the coordination of the work of the Pomeranian DistrictDivision of KOP when Piątkowski had left Pomerania. Piątkowski managed to organize the transfer point of KOP in Kutno using Polish railwaymen for this purpose. Piątkowski travelled to various places for organizational purposes. He visited not only Bydgoszcz, Grudziądz and Tczew, but also Poznań. However, the details of the journeys remain unknown.

After leaving Toruń Sub-Lieutenant Paweł Piątkowski alias "Podchorążak" installed himself in Kutno, from where he supervised the work of the Pomeranian District Division of KOP. Nevertheless, it had not been established when Piątkowski left Kutno for Warsaw. Supposedly, it occurred after the first arrests of the members of KOP in Torun. When he received the information about his sister Jadwiga Pohl's being arrested on 18 March 1940, who was one of his couriers, he moved to Warsaw for fear of being caught. Originally, he hid in Celestynów near Warsaw, from where he commuted to Warsaw, where he conducted his underground activity in KOP. In Warsaw he used to stay in Kossaka Street in the flat of Aniela Kuśnierek - the wife of the major of Division II kept in a camp for prisoners of war. It was there that he used to get in touch with the engineer Stefan Witkowski, who ran the intelligence organizations "Musketeers". It is known that other important flats where Piątkowski contacted the Main Headquarters of KOP were located in Mokotów, in Aleje Jerozolimskie, Aleja Niepodległości nd in Wilcza Street. In October 1940 Piątkowski married one of his couriers Zofia Turkowska alias "Zosia”, "Zofia Malinowska" and lived with her in Warsaw - first in Aleje Niepodległości, and later in Wiśniowa Street ${ }^{105}$. Halina Stenke was a person who in Warsaw conducted underground activity connected with Pomerania. She lived at 52/21 Narbuta Street. However, nothing else is known about her associations with KOP and her activity ${ }^{106}$.

105 T. Jaszowski, Piątkowski Paweł ps. "Podchorązak", przybr. nazw. "Wyleżyński", "Ziółkowski” (1916-1942), komendant Pomorskiego Okręgu KOP, SBKP, cz. 2, Toruń 1996, pp. 138-139.

${ }^{106}$ Halina Stenke born on 19 Sept 1911 in Koło in the county of Kalisz AMS, KLS t. pers. H. Stenke, sygn. I-III-15011, k. 1. There is a note on her card: "Dyspozycja na karcie Masiski Johann nr 10560". 
5. The work of the secret intelligence pillar

Henryk Borucki alias "Czarny", who, as the commander-in-chiefof $\mathrm{KOP}$, not only attached much significance to the creation of extended intelligence structures of KOP, but also got involved himself in the supervision over the intelligence activity in $\mathrm{KOP}$ and maintained direct contacts with leaders of individual intelligence or counter-intelligence cells, provided much information about the work of the secret intelligence and counter-intelligence pillar of KOP, the veracity of which is now hard to check. He had considerable knowledge about this pillar of KOP of the years 1939-1943 and later years. After the creation of The Polish People's Army (PAL) on the foundations of KOP, the structures of the intelligence service of PAL were also set up on the basis of KOP. It is worth presenting how Borucki showed the structures of the intelligence of KOP and its work in his postwar testimonies. However, it should be taken into account that he wished to show the activity of KOP to good advantage and underline his own achievement in the underground activity.

In one of his essays title "Intelligence and counter-intelligence" - prepared in the prison during the investigation conducted after the war in the Ministry of Public Security - Borucki included part (titled "The intelligence service of the organization the Defenders of Poland (KOP) - later the Polish People's Army"107. He wrote there: "As early as the beginning of November 1939 the intelligence service of KOP was well organized and started its activity as part of the so called Departments of Security. The network of this service and the intensity of its work developed systematically along with the relatively quick growth of the organization itself. In the first half of 1940 the intelligence network of KOP was developed to such an extent that it covered not only all the areas of prewar Poland, but also reached Gdańsk up to East Prussia, Silesia and even some centres in the Reich. The organization of the intelligence service and its methods of work were originally based on the models of the prewar "dwójka" ["cell of two"], adapted to the existing war conditions. From the very beginning of the activity, the results of work of the organization exceeded our boldest expecta-

${ }^{107} \mathrm{IPN}$ BU, sygn. 0330/246, t. 8. 
tions. The phenomenon could be explained by the fact that the intelligence service of KOP employed a huge quantity of meticulous, passionate and devoted officers. Irrespective of their work, we received a huge amount of information thanks to the organized collection of all the reports from all our organizational units. One of the duties of each member of KOP was an immediate notification of their observations to their superiors and even acquiring information about the issues indicated by their bosses. The organizational system was not very complicated" 108 .

District intelligence centres were subordinated to the intelligence headquarters - the Head of the Department of Security of KOP. They were referred to as District Departments of Security of KOP and consisted of county units and local units (Municipal Commissariats or rural communes). The central unit along with local units were centres where the work of the intelligence, counterintelligence and security organizations took place. They had at their disposal the whole apparatus of the intelligence, counterintelligence, subversion, sabotage, armed and active units of "Gwardia Ludowa" or "Milicja", legalization office, etc. ${ }^{109}$.

At the level of a county and region there operated only post of Militia (in the counties- platoons, in the regions - sections), which cooperated carrying out the tasks of the intelligence and counterintelligence ordered by a given district. They also collected reports from the whole territory ${ }^{110}$.

The significance of the intelligence units for the work of KOP goes beyond doubt. However, it seems that Henryk Borucki described this problem in an exaggerated way: "To my way of thinking, the intelligence service of KOP contributed significantly to the struggle with the occupying forces to defend the Polish Case as far as the self-defence of Polish society and the security of the organization were concerned. It also conducted actions to harm and make losses to the Germans. The highly efficient intelligence system directed against the Germans was

${ }^{108}$ Ibid., Wywiad organizacji Obrońców Polski (KOP) - później Polskiej Armii Ludowej, k. 201--202.

${ }^{109}$ Ibid., k. 202.

${ }^{110}$ Ibid. 
developed; almost all institutions and offices of the occupying forces were affected by the activity of the counterintelligence (including the Gestapo, the German intelligence service and all the police formations); it was there that the first militant groups, subversion and partisan units were organized. The intelligence service of KOP was the first to launch legalization offices issuing thousands of various documents both to members of almost all organizations (free of charge) and to non-members. It may be concluded that almost all pioneer pro-independence actions, all most risky attempts and the first breaches in the iron cage with which the Germans had terrorized Poles, were made or worked out by the intelligence service of KOP"11.

The intelligence service of KOP - set up in 1939 following the prewar rules of Section II of the Main Staff of the Polish Army - worked without any major alterations until the first more serious disclosure. Later on numerous changes and reorganizations of the Department of Security occurred. This is what Borucki wrote about his involvement in the work of the intelligence and counterintelligence: "I did my best to guarantee that this fundamental section of the underground work not lose its value and that its valuable parts be extended, shortcomings eliminated and that the whole work be done following new models adapted to the new conditions. I wanted to harmonize the cooperation between the intelligence and counterintelligence service with the security pillar of KOP (later PAL) excluding all harmful forms of bureaucracy typical of "dwójka" ["cell of two"]. Unfortunately, due to two serious disclosures (January 1941 and June 1942) I managed to achieve a satisfactory level of work of the whole intelligence institution at the beginning of 1943." 112

\section{Propaganda and information policy}

From October 1939 to January 1940 the propaganda work in KOP was administered by the Civic

Patriotic Committee, which, despite the fact that it was not part of the Main Headquarters was supervised by Major Studziński, the first

${ }^{111}$ Ibid., k. 206-207.

${ }^{112}$ Ibid., k. 208-209. 
commander-in-chiefof KOP. The Committee was to reach broader groups of Polish society through the propaganda activity. The propaganda of KOP was not only to transmit the information cheering up the readers, but also promote the organization and win support for the actions of KOP, particularly those concerning its military pillar ${ }^{113}$. In this original period it was the propaganda pillar that got the best results - much better in terms of activity and efficiency than other pillars of KOP. What contributed to this success was the press pillar of KOP - the paper Polska Żyje ${ }^{114}$. It was the second secret paper published in Warsaw- its first issue appeared as early as 10 October 1939 with the circulation of 6,000 copies $^{115}$. Originally, the paper was typed with a duplicating machine, but relatively quickly it started to be printed. The material background, organization, the editorial staff and incredibly high circulation (up to 40,000 copies) determined its success ${ }^{116}$. The head of the editorial committee was Witold Hulewicz ${ }^{117}$. He managed to invite the cooperation of famous prewar writers and journalists. The team consisted of Professor Basiński, Witold Bieńkowski ${ }^{118}$, Professor

${ }^{113}$ M. Wiśniewski, Z historii..., pp. 230-231.

${ }^{114}$ Sometimes called 'Peżetka'.

115 S. Lewandowska, Polska konspiracyjna prasa informacyjno-polityczna 1939-1945, Warszawa 1982, p. 36. The first underground paper was “Monitor Informacyjny ZPN" issued in Warsaw on 3 October 1939, the press body of the Association of Indepedence Insurgents.

${ }^{116}$ Ibid., pp. 36 and 142.

117 Witold Hulewicz alias “Olwid”, “Grzegorz” (1895-1941), a poet, literary critic, translator and publisher. He quickly joined the underground structures of KOP. He was not only the editor of Polska Żyje. Thanks to his excellent command of the german language, he edited underground brochures also in German for German soldiers. He was arrested on 2 Sept 1940 and executed on 12 June 1941 in Palmiry. During the occupation in 1941 his peom was printed in Antologia poezji wspólczesnej, and in 1942 his poetry was published in the underground anthology titled Pieśń niepodległa edited by czesław Miłosz. He was buried in the cemetery in Palmiry.

${ }^{118}$ Witold Bieńkowski alias “Dr Kalski”, “Jan”, “Kalski”, “Wencki” (1906-1965), a journalist and politician. Before the war he was a journalist in "Ilustrowany Kurier Codzienny" and "Głos Narodu". During the occupation after he finished his cooperation with KOP, he joined the Front of the Rebirth of Poland. In 1942 he joined the Temporary Committee for the Help to the Jews. In October 1942 he became the head of the prison unit (KW). In February 1943 he became the head of the Jewish branch in the Department of Home Affairs of the Government Delegation for Poland. He became a permanent representative of this body in the Council for the Help to the Jews "Żegota". 
Wacław Borowy ${ }^{119}$, a famous writer Zofia Kossa-Szczucka ${ }^{120}$, Stanisław

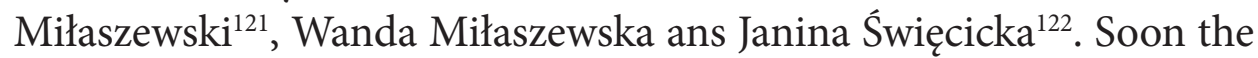
team acquired new members: Jadwiga Czerniawska, Tadeusz Hertlem, Mieczysław Krzepkowski, Adam Próchnik, Stefan Magenheim, Andrzej Wierciński and others ${ }^{123}$. The team included people who had been previously involved in the political activity and evincing crystallized opinions.

Within KOP, apart from the paper Polska Żyje, other papers were issued, too. In Warsaw the following papers were published by KOP: Biuletyn Radiowy, Chłopski Bój, Czuj Duch, Głosy Świata and Wici'24. Most of those papers were published by underground groups incorporated by KOP, which continued their publication within KOP. In Warsaw from 10 October 1940 the paper Orlęta was issued. It was devoted to the youth and its circulation was quite significant. Zofia Kossak-Szczucka cooperated with this paper as she had experience in writing books for young people. Other people who cooperated with Orlętaincluded a famous left-wing activist and historian Adam Próchnik, an activist of the socialist wing Janina Święcicka, and professors

${ }^{119}$ Wacław Borowy (1890-1950), born on 19 May 1890 in Tuczynek near Łódź. He studied at the University of Lviv and the Jagiellonian University in Cracow (Polish philology and English philology). In the years 1921-1928 he was the curator in the Library of Warsaw University. From 1931 a member of the Polish PEN Club. In the years 1930-1935 he worked in Great Britain in an English school. After 1935 he was the head of the Library of Warsaw University. By the outbreak of the war he cooperated with the Programme Department of the Polish Radio. In 1938 he became an assistant professor and the head of the Department of the History of Polish Literature at Warsaw University. During the occupation he lived in Zalesie near Warsaw. He used to give underground secret classes to students of Polish philology and English philology of Warsaw University. He cooperated with underground press.

${ }^{120}$ Zofia Kossak-Szczucka (1889-1968), a novelist. See: A. K. Kunert, Ilustrowany przewodnik..., s. 511; N. Wójtowicz, Jeszcze o świadectwie życia Zofii Kossak, Nasz Głos, 2007, nr 8-9, pp. 25-26.

${ }^{121}$ Stanisław Miłaszewski (1886-1944), a playwright, journalist, poet and translator.

${ }^{122}$ AMS, rel. H. Boruckiego.

${ }^{123}$ M. Wiśniewski, Z historii..., p. 232.

${ }^{124}$ During the investigation conducted against Borucki by the Ministry of Public Security the officers took over the Information Bulletin 'Wici' - belonging to KOP of 13 Jan 1943. IPN BU, sygn. 0/330/246, t. 1, k. 399, Wykaz dokumentów H. Boruckiego stanowiących depozyt nr 5021, poz. 19. 
Basiński and Wacław Borowy ${ }^{125}$. The paper Orlętaappeared for a relatively short time - its last issue took place in January 1941. It was one of the few paper aimed at young readers.

Papers of KOP were issued also in other cities, but they reached only local readers. The biggest number of such papers were printed in Cracow, where the bulletins "Dziennik Radiowy" and "Komunikat OP along with papers Polska Walczy and Zbrojna Rozprawa appeared. In Cracow in the years 1939-1941 KOP issued also the paper "OP" (Obrońcy Polski) ${ }^{126}$. In Silesia there were published the papers Leć Orle Biały and Mściciel. In the Lublin district Zemsta was issued ${ }^{127}$.

In the first issue of Polska Żyje of 10 October 1939 the message broadcast by the Polish Radio from France ${ }^{128}$ was published. It concerned the change in the position of President of the Rzeczpospolita and appointment of General Władysław Sikorski to the office of the president of the Council of Ministers and the Minister of Military Affairs, which was done by the new President of Poland Władysław Raczkiewicz $^{129}$.

The copies of the underground press often included instructions saying: "Don't destroy!", "Read and give it to another person to read!", "Respect the work of a typographer". In the first issue of Polska Żyje there was a remark: "The Bulletin cannot reach the hands of the enemy! Don't throw it away! Don't lose it! Don't destroy! Read and give it to a good Pole to read!" 130 .

In May 1940 in Polska Żyje the best known Decalogue of the civic morality titled Bojkot najeźdzcy was published. It included the basic

${ }^{125}$ AMS, rel. H. Boruckiego.

${ }^{126}$ S. Lewandowska, Polska konspiracyjna..., p. 37.

127 See: L. Dobroszycki, Centralny katalog polskiej prasy konspiracyjnej 1939-1945, Warszawa 1962.

${ }^{128}$ It was broadcast on short waves provided by the French Radio, which made it available to the Polish Radio.

${ }^{129}$ M. J. Kwiatkowski, Polskie Radio w konspiracji 1939-1944, Warszawa 1989, pp. 3334.

${ }^{130}$ Polska Żyje, nr z 10 X 1939 r. Only some underground papers included the instruction: "After reading destroy!” or "After reading destroy it yourself!". See: Archiwum Uniwersytetu Gdańskiego, A. Gąsiorowski, Pomorze Gdańskie w świetle wydawnictw konspiracyjnych 1939-1945, Uniwersytet Gdański, (maszynopis pracy doktorskiej), t. I, Gdańsk 1979, p. 14. 
rules of conduct to be followed by Polish society under the German and Soviet occupation ${ }^{131}$. In 1941 the Department of Propaganda of KOP published Kalendarzyk KOP-u 1941, which appeared as the chargeable supplement to Polska Żyje and Orlęta. It included the guidelines for Polish citizens to follow in the occupation period ${ }^{132}$.

In August 1940 in KOP the so called section of special propaganda was created under the supervision of Zygmunt Jurkowski alias "Kulesza". He prepared various leaflets in German Soldaten und Genossen! (Soldiers and Comrades!), which was disseminated among Germans and sent to Wehrmacht soldiers via military mail. KOP also edited a satirical illustrated paper "Erika" in the German language and aiming exclusively at German soldiers ${ }^{133}$.

It is worth underlining that Polish society highly appreciated the propaganda activity of KOP in the years 1939-1941; the papers issued by KOP had not only high circulations, but also a major distribution in Warsaw, the General Government and other regions ${ }^{134}$. Officers of the German Security Police noticed the anti-German propaganda activity of KOP. In April 1941 the head of the Security Police in the Lublin district in his report sent to the Main Bureau of the Security of the Reich wrote: "KOP turned into the best propaganda organization. It issued the weekly 'Polska Żyje', the paper for the youth 'Orlęta' and the communist paper in the German language 'Żołnierze frontowi!

${ }^{131}$ Bojkot najeźdźcy, Polska Żyje, nr 47-48 z 1 V 1940 r. Earlier there appeared in the paper 'Pobudka' nr 12 of 18 IV 1940 under the same title Bojkot najeźdźcy the text of the decalogue in a somewhat changed version and referring only to the territory of the German occupation. The text from the paper 'Polska Żyje' was reprined in 'Biuletyn Informacyjny’ of 10 V 1940. See: A. K. Kunert, Ilustrowany przewodnik..., p. 51.

${ }^{132}$ Ibid., p. 27.

${ }^{133}$ There is no information about this paper of KOP in German documents; there was a debate in the 1960s whether this paper had been issued by KOP. See: J. Rzepecki, Jeszcze o..., p. 412; H. Borucki, O powstaniu i działalności..., p. 377.

${ }^{134}$ T. Szarota, Okupowanej Warszawy dzień powszedni, Warszawa 1973, p. 377, writes: 'Until mid-1940 »Polska Żyje!« was the most popular underground paper in Warsaw'. Comp. K. Ciechanowski, Ruch oporu..., p. 90, ho stated: “The September defeat, the German terror in Pomerelia in the first months of the occupation and the series of extermination actions and administrative regulations directed against the Polish population made it necessary to counteract the collapse of morak powers of the Pomeranian community. The significant distribution of the paper of KOP »Polska Żyje! « played a major role in this field - the paper reached even the northern parts of Pomerelia. 
Towarzysze!' [Soldiers at the front! Comrades!] along with the calendar for 1941. The paper 'Polska Żyje' was willingly read by the Polish population and it achieved the major propaganda success. The inciting leaflet in German 'Soldiers at the front! Comrades!' was widely distributed among the Germans, particularly Wehrmacht soldiers and the police. Its aim was also to disturb the relations with the Soviet Union. The place where its distribution was the biggest was the Lublin district. It was even smuggled through in letters sent via military mail from the motherland"135.

${ }^{135}$ Cited after: M. Wiśniewski, Z historii..., p. 238.






\section{Chapter II}

\section{THE POMERANIAN DISTRICT DIVISION \\ OF THE HEADQUARTERS \\ OF THE DEFENDERS OF POLAND (KOP) \\ (the development of the organization and structure)}

1. The role of Piątkowski and Odrowski in the creation of the Pomeranian District Division of KOP

KOP was probably the first Polish underground organization which set up its structures in Pomerania occupied by the German army. The units of KOP started to be established at the beginning of the occupation period, supposedly when the prewar Pomeranian networks of subversion beyond the front-line, contacted by the Service for Poland's Victory, were activated. Now it is hard to state whether it was Sub-Lieutenant of aviation Paweł Piątkowski alias "Jackowski", "Marek" ${ }^{136}$ who originated the work on the creation of the Pomeranian District Division of KOP, or it was Polish emissaries of the Service for Poland's Victory who were the first to appear in Torun. The question is difficult to answer as there has been a conflict among the emissaries of the Service for Poland's Victory, which probably shall never be resolved unless new sources have been discovered ${ }^{137}$.

${ }^{136}$ IPN BU, sygn. 0330/246, t. 8, k. 73. H. Borucki gave there the codenames of P. Piątkowski "Jackowski” and "Marek".

${ }^{137}$ B. Chrzanowski, who has conducted the research on the SZP-ZWZ-AK in Pomerania for years thinks that there were two emissaries. See: B. Chrzanowski, Wrzesien 1939 i początki Polskiego Państwa Podziemnego na Pomorzu, [in:] Warszawa i stolice regionalne II RP we wrześniu 1939 roku i w początkach Polskiego Państwa Podziemnego, pod 
Thus - not resolving the issue - one may assume that more or less at the same time - in October 1939 - in Torun there started the creation of the structures of the local organization "Grunwald", based on the prewar Pomeranian networks of subversion beyond the front-line prepared before the war by Branch II of the Main Staff of the Polish Army and the Pomeranian structures inspired from Warsaw: KOP and the Polish army acting in conspiracy - the Service for Poland's Victory (soon converted into the Union of Armed Struggle). It is necessary to underline this now as it is extremely hard or even impossible to establish the range of organizational work conducted by KOP, "Grunwald" or the Union of Armed Struggle. The situation is further complicated by the fact that "Grunwald" fell apart at the beginning of 1940 into two parts. One of them later developed into the Pomeranian District Division of the Union of Armed Struggle, whilst the other commenced cooperation with the Main Headquarters of KOP only to become part of $\mathrm{KOP}^{138}$.

It is not known how Paweł Piątkowski established his first contact with KOP, which at that time was referred to as the Defenders of Poland. In the postwar accounts it reads that Piątkowski in the summer of 1939 stayed in Torun, where he had been sent for officer's apprenticeship in the $4^{\text {th }}$ Aviation Regiment. It turns out that after the evacuation of the army from Torun, he was ordered to stay in Pomerania and set up the resistance movement ${ }^{139}$. Thus, it is hard to say why he eventually left Torun for Warsaw. The only thing we know is that Piątkowski was in Warsaw in September 1939, where he took part in the defence of the capital city. However, in the sources available there are no records about what he had been doing directly before the capitulation of Warsaw and in the first days of the occupation period. However, he returned from Warsaw to Toruń, where he appeared on 3

red. M. M. Drozdowskiego i H. Szwankowskiej, Warszawa 2002, p. 198; A. Gąsiorowski, Poczatki pomorskiej konspiracji 1939/1940, [in:] Polska Podziemna na Pomorzu 1939-1945, Gdańsk 2005, pp. 94, 101.

${ }^{138}$ The problem shall be explained in the next part of the book.

139 AMS, Kolekcja Konrada Ciechanowskiego [further cit: Kol. K. C.], Notatka z rozmowy z Aleksą Szewą z 29 VI 1961. 
October 1939, starting his underground activity ${ }^{140}$. His sister Jadwiga Iwańska many years after the war said: "When the war broke out, he was staying in Warsaw and was captured there by the Germans. He had shed all the officer's patches to be treated as a common soldier. He hoped to go unnoticed by the enemy. While the prisoners of war were being transported through his family town Torun, he imperceptibly joined the crowd of people and returned home on 3 October 1939. From the very moment he came back home, he repeated that he was bound by the vow and had to serve to the motherland. In October he left for Warsaw with the intention of finding Polish officers there. He came back to Torun, happy to be able to work for the important issue. He settled down in Warsaw and lived there until he got arrested"141.

At that time he used the codename "Podchorążak". However, there are some doubts concerning his first contact with KOP. Major Bolesław Studziński must have known about Piątkowski's joining KOP and his being appointed the commander of the Pomeranian District Division of KOP. Still, little is known about the activity of Studziński in Warsaw in the first days under the occupation ${ }^{142}$. It is possible that Piątkowski was introduced to KOP by Tadeusz Odrowski alias "Pomian", "Sok", "Odra", who was the head of the Inspectorate of the Western Territories of KOP, which also included the Pomeranian DistrictDivision ${ }^{143}$. The only thing we know is that Piątkowski maintained direct and frequent contacts with Tadeusz Odrowski. According to one account, he met Odrowski in the contact place in the bar "Zosia" in Polna street in Warsaw, run by the restaurant-owner Dawidowski from Torun ${ }^{144}$.

There are many hints indicating that Tadeusz Odrowski, who ran the Inspectorate of Western Territories of KOP, supervised and in-

${ }^{140}$ In his extensive works and postwar testimonies Henryk Borucki does not mention about it.

${ }^{141}$ AMS, Kol. K. C., J. Iwańska, Życiorys Pawła Piątkowskiego, Szczecin 31 I 1974.

${ }^{142}$ What can be concluded is that Major Studziński died relatively early. It happened in April 1940. Thus, there is no data about the origins of kOP in Warsaw. See: M. Wiśniewski, Z historii..., p. 231.

${ }^{143}$ T. Jaszowski, Piatkowski..., p. 138, writes: 'He maintained contact with Tadeusz Odrowski, and through him with KOP. (It is not certain whether it took place in Torun nor Warsaw)'.

${ }^{144}$ AMS, rel. T. Regenta. 
spired the organizational work of KOP in the western territories of Poland (including Pomerania) - before the war had cooperated with Branch II of the Main Staff ${ }^{145}$. During the occupation period he incorporated his organization - "Odra" - into KOP. Another proof of Odrowski's involvement in underground activities and his experience in this field is the fact of his being the co-founder of the Military Organization of Pomerania in the period of the struggle for independence, an activist in Powiśle and Warmia, a supporter of the Polish special actions in this territory. In May 1920 on behalf of Polish activists from Powiśle, Odrowski presented in Warsaw the project of organizing a military uprising in the area ${ }^{146}$. The project was not approved of, but it seems that in subsequent years Odrowski's links with Branch II were quite close ${ }^{147}$.

Undoubtedly. Officers of Branch II found it useful that Odrowski knew the territory and local Polish activists with whom he had cooperated during the interwar period ${ }^{148}$. On the basis of one account it may be stated that his involvement in the preparation of Pomerania for the situation of a possible German occupation rose significantly in 1938, when Odrowski started to create his own underground organization. After the assembly of insurgents from Greater Poland in Gdynia in 1938, Tadeusz Odrowski - at that time the president of the Association of Veterans of National Uprisings in Pomerania - informed Tadeusz Regent about his intention to set up such an organization. According to Odrowski it was to launch its activity after the outbreak of the war $^{149}$.

${ }^{145}$ In the letter of the Grudziądz Gestapo to the Gestapo in Ciechanów of November 1942 it said that as far as the prewar activity of Odrowski was concerned, it was known that he was the "former officer of the Polish intelligence". See: IPN BU, 0207/7918, Akta placówki gestapo w Ciechanowie, k. 37, Pismo placówki gestapo w Grudziądzu, nr IV E 5 - 6218/125-50/42g z 20 XI 1942.

146 A. Gąsiorowski, Geneza i początki..., p. 14; A. Barganowski, Plebiscyt na Ziemi Kwidzyńskiej, Zeszyty Kwidzyńskie, 2000, nr 1 pt. Plebiscyt na Powiślu - 11 lipiec 1920 roku, p. 63; K. Przyborowski, "Mała Polska”, p. 94.

${ }^{147}$ See: IPN BU, sygn. 0207/7918, Pismo placówki gestapo w Grudziądzu do gestapo w Ciechanowie nr IV E 5 - 6218/125-50/42g z 20 XI 1942.

${ }^{148}$ See: more in Tadeusz Odrowski's biogram attached at the end of the work.

${ }^{149}$ AMS, rel. T. Regenta. 
Odrowski founded his organization mainly on the basis of former participants of the Greater Poland Uprising. He informed Adam Poszwiński, an insurgent and Christian-national political activist in Poznan about the creation of his organization ${ }^{150}$. Members of Odrowski's organization supposedly acted as part of the so called Social Network of Information (SSI), which, upon the order of the Main Inspectorate of Armed Forces, was set up in all Headquarters of the Districts of Corps (DOK) including DOK VIII in Torun operating in Pomerania ${ }^{151}$.

On the basis of the account by Teodor Regent, a member of Odrowski's organization, it was possible to reconstruct only part of the personnel composition of the organization from Swiecie. It is known that 12 people belonged to the organization including the mayor of Świecie Mieczysław Słabędzki; the police constable Antoni Dzwoniarek; Brunon Hoffmann, a clerk in the court and an activist of "Sokól" in Świecie; an activist of the Association of Reserve Officers Sub-Lieutenant Stanisław Borysiak ${ }^{152}$, a tradesman Teodor Regent and his relative - scoutmaster - Czesław Porożyński. Near Chełmno, where Odrowski had lived before the war, the organization recruited the head of the post office Józef Kasprzyk, a former participant of the Greater Poland Uprising. All the members of Odrowski's underground organization were sworn in in his presence. Before the outbreak of the war the full meeting of the organization had never taken place. Their contacts consisted in social meetings organized in Swiecie in Chełstowski's place and the house of the mayor Słabędzki.

Members of Odrowski's network before the war had collected information about the activity of the German minority. They followed

150 Adam Poszwiński (1881-1942), member of the Commissariat of the Supreme People's Council in Poznań, later sub-secretary of the state in the Government of Poland, editor and journalist in "Gazeta Pomorska" and "Dziennik Bydgoski”. See: M. Woźniak, Poszwiński Adam, [w:] Encyklopedia konspiracji wielkopolskiej 1939-1945, pod red. M. Woźniaka, Poznań 1998, pp. 462-463; W. Grabowski, Polska tajna..., pp. 49, 107, 317.

${ }^{151}$ B. Polak, Powstańczy rodowód polskiej konspiracji wojskowej w Wielkopolsce 19391942, [in:] Z dziejów konspiracji wojskowej na tzw. ziemiach wcielonych do Rzeszy 19391945, Koszalin 1988, pp. 567-582; P. Bauer, B. Polak, Armia Poznań w wojnie obronnej 1939, Poznań 1983, pp. 105-106.

${ }^{152}$ Sub-Lieutenant Stanisław Borysiak in the years 1920-1929 was an officer of 62 Infantry Platoon in Bydgoszcz. 
the meetings of German activists. After the outbreak of the war they were to use the password "Wisła"153.

Undoubtedly, the organization set up before the war by Odrowski had its structures also in other cities and towns in Pomerania, Powiśle, Warmia and Mazury. From 1939 Odrowski stayed permanently in touch with Polish activists from those territories ${ }^{154}$.

Not much information about Tadeusz Odrowski's postwar life can be found in his postwar testimonies. It turns out that on 4 September 1939 he left Chełmno for Warsaw. However, he did not manage to reach Warsaw owing to the quick advance of the German forces, which made it impossible for him to move towards the south of Poland. Germans told him to return to his place of residence ${ }^{155}$. In 1947 he said: "Having returned to Chełmno I remained in hiding until 1 December 1939, when I went to Włocławek and later to Warsaw, where I stayed until the outbreak of the uprising. In Warsaw I dealt with gardening and trade; I stayed at 6 Chłodna Street"156.

As it can be concluded from the documents of the Gestapo in Grudziądz, Odrowski was lucky to remain in hiding after arriving in Chełmno ${ }^{157}$. After the outbreak of the war in September 1939, the Gestapo searched for him as his surname was found in the special book of wanted Poles (Sonderfahndungsbuch Polen) ${ }^{158}$.

Little is known about Tadeusz Odrowski's underground activity in Warsaw. Not much can also be found in his postwar testimony of 17 Jan 1947. He provided very general explanations saying: "Originally from 1940 to 1944 I took part in the underground work distributing leaflets, writing brochures against the occupying forces; I used the

${ }^{153}$ AMS, Rel. T. Regenta z 7 I 1981.

${ }_{154}$ T. Oracki, Słownik biograficzny Warmii, Mazur i Powiśla XIX i XX wieku (do 1945 roku), Warszawa 1983, pp. 235-236.

${ }^{155}$ During the interrogation in Wrocław in January 1947 Tadeusz Odrowski responded to the questions as follows:"From 4 September 1939 I left Chełmno for Warsaw, but the Germans caught us up very quickly and told us to go back home". See: IPN Wr, sygn. Wr 21/1619, Akta Wojskowego Sądu Rejonowego we Wrocławiu w sprawie przeciwko T. Pomian-Odrowskiemu, protokół przesłuchania podejrzanego T. Pomian-Odrowskiego z 17 I 1947 r., k. 31.

${ }^{156}$ Ibid.

${ }^{157}$ Ibid. They only said that Odrowski had disappeared.

${ }^{158}$ AMS, Sonderfahndungsbuch Polen,photocopy, 
codenames "Pomian" and "Sok"159. I did the underground work in the military group of the organization. My involvement in the resistance movement can be confirmed by: 1) Władysław Kuklinski, captain or major of the service in Warsaw in the Ministry of National Defence; 2) Kaszubowski - living in Bydgoszcz, a jeweler; 3) priest Maćkowski Jan - the provincial of the Society of the Catholic Apostolate. I do not remember anything else"160.

Odrowski's testimony of 25 Jan 1947 includes somewhat more information, but the text is vague and only partly legible: "I arrived in Warsaw from Poznań province as I was forced to escape in December 1939, and in January 1940 along with friends from Pomerania, who also stayed in Warsaw and were members of the underground organization the Corps of Defence [illegible text] in 1919 the organization was dissolved after Poland had regained independence ${ }^{161}$, its members becoming members of the Society of Veterans of the Rzeczpospolita; we met in 1940 with other old members of the organization and decided to set up such an organization again to start fighting [further text illegible]"162. As it may be concluded, Odrowski after the war did not admit to holding the important office in KOP and working in the command structures of KOP. It should not surprise anybody as after the war had finished, he did not return to Pomerania, but stayed in Lower Silesia, where he had been staying after the capitulation of the Warsaw Uprising, using the surname Pomian-Odrowski ${ }^{163}$.

In fact, the only more detailed information about the underground activity of Odrowski was provided by the tradesman from Świecie Te-

${ }^{159}$ Odrowski did not confess to using more codenames such as 'Odra'.

${ }^{160}$ IPN Wr, sygn. Wr 21/1619, Akta Wojskowego Sądu Rejonowego we Wrocławiu w sprawie przeciwko T. Pomian-Odrowskiemu, protokół przesłuchania podejrzanego T. Pomian-Odrowskiego z 17 I 1947 r., k. 31.

${ }^{161}$ Supposedly, part of the blurred text concerns the Military Organization of Pomerania [OWP], the co-founder and commander of which Odrowski was in December 1918.

${ }^{162}$ IPN Wr, sygn. Wr 21/1619, Akta Wojskowego Sądu Rejonowego we Wrocławiu w sprawie przeciwko T. Pomian-Odrowskiemu, Protokół przesłuchania T. Pomian-Odrowskiego z 25 I 1947, k. 39. So, the most important part of Odrowski's testimony concerning the original period of his underground activity cannot be used now.

${ }^{163}$ IPN BU, Protokół przesłuchania T. Pomian-Odrowskiego z 15 I 1947, k. 16. 
odor Regent, who before the war had been a member of Odrowskis network and cooperated with him during the occupation period ${ }^{164}$.

According to Regent, one of the members of Odrowski's organization in Pomerania from the beginning of the occupation period was Stanisław Borysiak from the vicinities of Jarocin, who maintained communication with Benedykt Porożyński, residing in the General Government, the instructor of the Gray Ranks and officer of the Union of Armed Struggle - Home Army [ZWZ-AK]. Józef Kasprzyk, hiding first in Pomerania and later in Kutno, was also quite active. He organized the transfer of people to the General Government. He generated documents with false names since his brother-in-law (a volksdeutsche) had access to genuine blank forms. It is known that Borysiak was arrested by the Gestapo, but it was impossible to establish the date and circumstances of his disclosure ${ }^{165}$.

Not much is known about the underground activity of Odrowski in the General Government. In Warsaw he set up a contact point for his network in the bar "Zosia" in Polna Street, which was run by Dawidowski, who before the war had had his own restaurant in Dworcowa Street in Bydgoszcz. He was assisted by his son Henryk Dawidowski. The following people met in "Zosia" with Odrowski: Włodarczyk alias "Wludersag"; Teodor Regent and Zygmunt Felczak alias "Bydgoski", "Jasiński", "Zygmunt", a leading activist of the underground Labour Party ${ }^{166}$, who before the war had done some special tasks for the Polish army. During the occupation Felczak was one of the most active political Pomeranian activists operating in Warsaw, who maintained

${ }^{164}$ AMS, Rel. T. Regenta z 7 I 1981.

165 Ibid.

166 Zygmunt Felczak alias "Bydgoski”, “Jasiński”, “Zygmunt” (1903-1946), before the war he was the secretary of the District Board of the National Workers' Party in Pomerania, from 1934 he was a member of RN NPR, and from 1935 a member of the Main Executive Committee of NPR. He was the president of the Mani Board of the Association of Working Youth "Jedność" and the chief editor of the paper "Demokrata". After the Labour Party was set up in 1937, he became a member of the Main Board of the Labour Party. More about him: A. K. Kunert, Słownik biograficzny..., t. I, Warszawa 1987, pp. 64-65; W. Grabowski, Polska tajna..., pp. 135, 137, 303; B. Chrzanowski, A. Gąsiorowski, K. Steyer, op.cit., pp. 208, 237. 
contacts with Pomerania ${ }^{167}$. We can only suppose that Odrowski contacted him as an activist of the Labour Party associated with Antoni Antczak - the Government Delegate for the Pomeranian District ${ }^{168}$. After the bar "Zosia" was exposed, Odrowski chose another contact point in the confectionery of Blikle. The only thing we know is that Klimczuk attended the meetings there.

According to the account of Teodor Regent, Odrowski took part in the action of getting weapons from the weapon factory in Radom or its vicinities. He carried out the action along with his subordinates. All the participants of the action wore German military uniforms. Odrowski and his people arrived at the factory in two cars equipped with two trailers. Odrowski used falsified authorization documents to collect the weapon, which was later transported to Warsaw. They left the factory with two cars and trailers filled up with weapons. Supposedly, Odrowski also had some contacts in West Pomerania ${ }^{169}$.

Now it is hard to establish when Odrowski broke off contacts with KOP. We only know that in 1942 he maintained secret contacts with the scoutmaster Reserve Lieutenant Benedykt Porożyński alias "Beni" - a member of the Headquarters of the Gray Ranks and officer of the Home Army, who lived in Mińsk Mazowiecki and maintained constant communication with Pomerania. Upon the order issued by Odrowski, Regent used to see Porożyński, who happened to be his relative, on a regular basis ${ }^{170}$.

2. The appointment for the position of the commander of the Pomeranian District Division of KOP

It is not known who ran the Pomeranian District Division of KOP after Piątkowski had been arrested in November 1940. In the sources

${ }^{167}$ Felczak maintained close contacts with Torun, particularly with Franciszek Rochowiak - the head of the branch of ODR in Torun, who supported Felczak's appointment to the post, when the Labour Party had split. See: K. Ciechanowski, Ruch oporu..., p. 285.

${ }^{168}$ There is no closer data about Felczak's involvement in the works connected with the creation of structures of ODR in Pomerania. See: B. Chrzanowski, Delegatura Rzadu na Kraj na Pomorzu. Nieznane karty z frontu walki cywilnej podczas okupacji niemieckiej i po jej zakończeniu, Toruń 2011, p. 163.

${ }^{169}$ AMS, Rel. T. Regenta z 7 I 1981.

170 Ibid. 
available there is no information whether there took place an attempt to reconstruct the district after it had been crushed by the Germans in the late autumn of $1940^{171}$. Krzysztof Komorowski in his lexicon devoted to the underground movement in Pomerania of 1939-1947 included a piece of information, which is very hard to confirm, that in the original stage the commander of the Pomeranian District Division of KOP was Captain Sergiusz Kostecki alias "Czarny", who later joined the Polish Army of Resurrection [PAP] ${ }^{172}$.

Currently, on the basis of the available documents, one may only put forward a hypothesis that Sergiusz Kostecki was not the commander of the Pomeranian District Division of KOP in the original stage. Probably he made an attempt to reconstruct the structures of the Pomeranian District Division of KOP after the first arrests by the Gestapo in the spring of 1940. Kostecki himself after the war gave various dates of his arrival in Pomerania in the occupation period. In his testimonies of 1947 he said: "Approximately in March 1940 I got in touch with the underground organization $\mathrm{KOP}$, holding the function of the counselor of the regiment with the rank of lieutenant. In June 1941 I received the order from the Headquarters of the Corps of the Defenders of Poland ${ }^{173}$ to go to Pomerania (at that time "Reich") in order to organize militants groups to fight with the Germans. In June 1941 I crossed the border and got to Torun, where I lived in the flat of my cousin Irena Kostecka. For two months I set up militant groups and in August 1941 I returned to Warsaw as the German terror had increased significantly. After several weeks in Warsaw I received the order of going back to Pomerania. In September 1941 I crossed the border again and settled down in Chełmża (the county of Toruń). I stayed in the flat of a railwayman Mileski in Dworcowa Street. After a few days in Chełmża I was employed in the sugar plant in Chełmża in the position of the third chemist, where I worked until 10 January

171 The commander-in-chief of KOP from April to may 1940 Henryk Borucki alias "Czarny" in his conversation with K. Ciechanowski in 1965 said he did not remember who had maintained contact with Pomerania after Piątkowski’s being arrested. See: AMS, Kol. K. C., Notatka z rozmowy z H. Boruckim z dnia 16 XI 1965.

${ }^{172}$ K. Komorowski, Konspiracja pomorska 1939-1947. Leksykon, Gdańsk 1993, p. 85.

173 There should be: the Headquarters of the Defenders of Poland 
1942. From 10 January 1942 to September 1942 I remained in hiding in the flat of my cousin Irena Kostecka in Torun. At the end of September I was employed in the sugar plant "Unisław" in Chełmno (the county of Chełmno) as the second chemist. In the "Unisław" sugar plant I worked until January 1943. From January 1943 to October 1943 I worked in the factory "Unamel" (the production of artificial honey) as the second chemist. In October I was arrested for my membership in the Polish Underground Army and imprisoned in the Gestapo jail in Torun, from where I was transported to the concentration camp in Stutthof near Gdańsk in March 1944"174.

During the next interrogation Sergiusz Kostecki declared that he had joined the underground organization at the beginning of April 1940 in Warsaw encouraged by his friend from the School of Officer Cadets at 77 Sub-Lieutenant Adam Kozłowski alias "Leszek", who was a member of $\mathrm{KOP}^{175}$ and the commander of the company. Having been sworn in, Kostecki was to organize his regiment of KOP in Warsaw, but he was unable to do it as he did not know anybody trustworthy in Warsaw. So, Kozłowski informed Kostecki that he would receive another organizational task. This is what Kostecki said about it: "In the period from mid-April 1940 to June 1940 I met Kozłowski once. At the meeting, which took place between 1 and 10 June 1940 "Leszek" / Kozłowski suggested that I should go to Pomerania to set up there underground groups of Poles to fight against the Germans. I agreed to his proposal. I did not receive any special tasks, but Kozłowski told me to examine thoroughly the area where I was to settle down, and give him my address in Pomerania, after which KOP was to send a special couriers with detailed instructions to me /Kostecki. I wish to stress that at that time I used the codename "Janek". I also wish to rectify my previous testimony in which I erroneously said that I had left for

${ }^{174}$ IPN BY, sygn. 85/356, Prokuratura Sądu Okręgowego w Toruniu, Akta w sprawie przeciwko Sergiuszowi Kosteckiemu, Protokół przesłuchania Kosteckiego z 11 VII 1947, k. 23.

${ }^{175}$ In the document it says: 'The Corps of the Defenders of Poland”. 
Pomerania in June 1943. In fact, I set off to Pomerania from Warsaw in June 1940, and not in June 1941"176.

Thus, it is now really hard to say which dates and data provided by Kostecki are true- whether he arrived in Pomerania as early as June 1940 or in June 1941.

\section{The structures of KOP in Torun}

In Torun the Headquarters of the Pomeranian District Division of KOP were set up. Piątkowski introduced to KOP Witold Lendzion ${ }^{177}$, who before the war had been the head of the Pomeranian District Division of the Youth Service of Obóz Zjednoczenia Narodowego - OZN [English: the Camp of National Unity] in Torun for a short time ${ }^{178}$. It seems that Witold Lendzion had contributed to special missions to be conducted in case of Pomerania being taken over by the Germans. We know that in September 1938 there took place in Torun a briefing of the Staff of the Youth Service of OZN of the Pomeranian District, attended by the head of OZN General Stanisław Skwarczyński and the head of the Association of Polish Youth - ZMP and the Youth Service of OZN Major Edmund Galinat, who in September 1939 was appointed the head of the secret military organization ${ }^{179}$, who was to contact mainly with the members of the Youth Service of OZN ${ }^{180}$.

${ }^{176}$ IPN BY, sygn. 85/356, Prokuratura Sądu Okręgowego w Toruniu, Akta w sprawie przeciwko Sergiuszowi Kosteckiemu, Protokół przesłuchania Kosteckiego z 16 VII 1947.

177 Witold Lendzion (1918-1983), born on 16 Nov 1918 in Torun, the graduate of the Gymnasium School under the name of Nicolaus Copernicus in Torun, which he finished in 1938. He did his military service in the School for Officer Cadets of the Centre of the Training of Cavalry in Grudziądz. He was called up as sergeant officer cadet; he took part in the war in September 1939 as the commander of the platoon 18 of the regiment of Uhlans. He was captured by the Germans on 2 October 1939 and escaped on 7 October 1939. After returning to Toruń, he was arrested and imprisoned in Fort VII, from where he escaped in November 1939. He was one of the first members of KOP in Torun.

${ }^{178}$ W. Lendzion took the position in April 1938, when the authorities started to spread their influence among pro-government youth organizations; in the subsequent years he was replaced by Major Adam Laszuk.

179 See: M. Ney-Krwawicz, Komenda Główna Armii Krajowej 1939-1945, Warszawa 1990, p. 38.

${ }^{180}$ P. Olstowski, Obóz Zjednoczenia Narodowego na terenie województwa pomorskiego. Zarys organizacji i działalności w pierwszym okresie istnienia (marzec 1937-luty 1938), [in:] Polska bez marszałka. Dylematy piłsudczyków po 1935 roku, zbiór studiów pod red. M. 
The head of the intelligence service of the Pomeranian District Division of KOP was Witold Lendzion. Couriers of the staff of the Pomeranian District Division of KOP were Zofia Jackowiak ${ }^{181}$ and Honorata Modrzyńska ${ }^{182}$. In the post-war accounts there appears also a reserve officer of the Polish Army Franciszek Zielke as a member of the Headquarters of the Pomeranian District Division of KOP. Before the war he had been the deputy commander of PW and WF in Toruń; supposedly he had taken part in the preparation of the underground structures in case Pomerania should be taken over by the German army ${ }^{183}$.

Not much is known about the development of KOP in Torun in the original period of its activity. We only know that the organizational officer of the Headquarters of the Pomeranian Distrcit of KOP and the commander of KOP in Torun became the officer of the fire brigade Reserve Lieutenant of the Polish Army Alfons Zaborowski alias "Zgrzyb"184.

Wołosa i K. Kani, Toruń 2008, pp. 315-316; J. Piotrowski, Piłsudczycy bez lidera, Toruń 2004; P. Olstowski, Obóz pomajowy w województwie pomorskim w latach 1926-1939, Warszawa 2008.

${ }^{181}$ Zofia Jackowiak palias 'Jacek' (1919-1986), born on 11 April 1919 in Gniszewo ten county of Tczew in a family of a profesional non-commissioned officer of the Polish Army. She was a graduate of the gymnasium school in Torun. She worked for the Military Training of Women [PWK]; she was an instructor and commander of PWK in Tuchola. In September 1939 after the evacuation of Tuchola, she stayed in Hrubieszów, where she worked in a military hospital. In October 1939 she came back to her parents to Torun and started working as a shop assistant.

${ }^{182}$ Honorata Modrzyńska (1921-1973), born on 21 July 1921 in Działdowo as a daugther of a craftsman. In 1937 she passed her secondary school examination "matura" and started studying in Warsaw, where she was staying when WWII broke out. In October 1939 she arrived in Torun and was sworn in by KOP. See: Fundacja Generał Elżbiety Zawackiej. Archiwum i Muzeum Pomorskie AK oraz Wojskowej Służby Polek (dalej cyt.: FGEZ), t. os. Modrzyńska Honorata; rel. W. Lendziona; t. Z. Jackowiak.

${ }^{183}$ In 1963 Zielke confessed that he had remained in touch with Lieutenant Piątkowski, who insisted that he join the underground movement. According to the postwar account, Zielke did not do it as he intended to to go to Western Europe to join the regular troops of the Polish Army. After he was arrested in Torun in March 1940, the Gestapo accused him of the underground activity, but they did not manage to prove him anything. AMS, Kol. K. C., Notatka z rozmowy z F. Zielke z 25 III 1963.

${ }^{184}$ Alfon Zaborowski alias "Zgrzyb" (190?-1940), no information about the date and place of his birth. He was born in a family of a railwayman. His father died in 1932. He graduated from the teacher training college and was a teacher. After doing the military service, he was promoted to the rank of reserve sub-lieutenant of the Polish Army. Before the war he became the officer of the fire brigade in Torun, which might be the evidence 
We also know that in Torun Bernard Domżalski ${ }^{185}$, employed in the city hall in Torun and a member of KOP since December 1939, was one of Zaborowski's subordinates. However, nothing is known about his role in $\mathrm{KOP}^{186}$. Zaborowski maintained close relations with Lieutenant of the Polish Army Waldemar Geringer ${ }^{187}$. Another member of KOP in Torun was probably Edmund Kamiński, but we did not succeed in establishing his function in $\mathrm{KOP}^{188}$.

Adam Przybyła ${ }^{189}$ alias "Stefan Bywalec", before the war an activist of the National Party [SN] in Toruń ${ }^{190}$, was relatively quickly invited to KOP. Piątkowski got in touch with him in Kutno, where Przybyła

for his being involved in the activities of the subversion beyond the frontline. Before the war he was a friend of Piatkowski, whi used to visit him in his house. See: FGEZ, t. os. Zaborowski A., sygn. M 1301/2144 Pom.; ibid., t. os. Drygałowa W., sygn. K 348/348 Pom., k. 17 i 19.

${ }^{185}$ Bernard Domżalski, the son of Jan and Wiktoria nee Stawska, born on 20 August 1903 in Mirakowo the county of Torun, lived in Toruń, at 38/8 Rybaki Street. IPN GK, 927/3123; OKBZH, Protokół przesłuchania świadka B. Domżalskiego, Bydgoszcz 10 I 1974.

${ }^{186}$ In the certifcate of the District Board ZBoWiD in Bydgoszcz of 28 August 1973 it was only generally stated that "Domżalski Bernard [...] from December 1939 was a member of the resistance movement called KOP in Torun commanded by Lieutenant Zaborowski". IPN GK 927/3123, k. 30.

${ }^{187}$ Waldemar Geringer (1913-1940) a professional oficer, reserve lieutenant of the Polish army, born on 5 Jan 1913; as an oficer he served in 63 Infrantry regiment in Torun. From the beginning of the occupation he actively got involved in the underground movement, originally in "Grunwald". He was the closes co-worker of Zaborowski, with whom he joined KOP. His function and activity in KOP are not known.

${ }^{188}$ AMS, Kol. K. C., Notatka z rozmowy z A. Szewą z 22 III 1965 r.

189 Adam Przybyła alias "Bywalec", "Stefan Bywalec" (1907-1985), born on 20 Dec 1907 in Wolsztyn the county of Babimost. In 1928 he worked as a setter in Wolsztyn, Leszno, Poznań and Gniezno. In the years 1928-1930 he did his military service in 88 Infantry Regiment in Mołodeczno in the Vilnius Region. After he returned from the army, he worked in the Printing Plant in Wolsztyn. He was also politically active as a member of the National Party [SN]. He was mobilized in August 1939, took part in the fight in September 1939. In October 1939 he returned to Toruń and was arrested by Selbstchutz. After a month he managed to get out of Fort VII and left Torun for Kutno, where he was invited to join KOP by Sub-Lieutenant Piątkowski. After his return to Toruń, he was a very active member of KOP and "grunwald". In May 1940 he started working in the printing house "Thorner Freiheit", which made it possible for him to steal various official blank forms (including he police ones) printed there.

190 See: A. Zakrzewska, Przybyła Adam, przybr. nazw. "Stefan Bywalec" (1907-1985) kmdt rejonowy KOP Toruń, SBKP, cz. 4, Toruń 1998, pp. 119-121. 
had arrived after his successful escape from Fortress VII in Torun in mid-October 1939. Przybyła was afraid of returning to Torun, whe he might have been looked for by the Gestapo. After Piątkowski had checked that Przybyła was not threatened by another arrest, Przybyła decided to leave Kutno for Torun and installed himself at 77 Żwirki i Wigury Street. Soon, he became one of the most active members of KOP in Torun. In October 1939 Marian Tuszewski contacted him. From Przybyła's account we know that Tuszewski ordered him to start working in a printing shop to be able to provide the organization with various blank forms printed there such as certificates, ID cards, passes, etc. Przybyła managed to do the task very well. His next task in KOP was to collect data, which he later passed on to Tuszewski, who next transmitted the information to Lieutenant Paweł Piątkowski. Anna Matuszak alias "Marysiä, residing in Toruń at 81/6 Żwirki I Wigury Street, was also in touch with Tuszewski. She became a member of the underground movement in July-August 1940 as Adam Przybyła's subordinate. She was a courier transmitting reports to various contact points in Torun, which were situated in the flats of the Ciesielski family, the Dalkowski family in Łazienna and the City Library in Wysoka Street, from where the information was collected by "Mechanik" (the name and surname uknown). Matuszak's contacts broke off in November 1940 after Z. Jackowiak had been arrested ${ }^{191}$.

Originally, Przybyła ran in Torun the intelligence activity and organized preparations for sabotage actions. Within KOP he maintained contacts with Lieutenant Władysław Jaworowski, who stayed in Kutno. His organizational activity was appreciated. In May 1940 he was appointed the commander of the region of KOP embracing the southern counties of the Reich District Gdańsk - Western Prussia (Reichsgau Danzig-Westpreussen): Brodnica, Chełmno, Lipno, Rypin, Toruń and Wąbrzeźno ${ }^{192}$. Przybyła invited more people to join

${ }^{191}$ On Sunday 6 July 1941 A. Matuszak was rrested in Toruń during a roundup. She was transported along with other people to the concentration camp in Stutthof, from whish she was released six weeks later. After her return to Torun, she broke off contacts with the underground. AMS, rel. A. Matuszak.

${ }_{192}$ MS, t. pers. A. Przybyły, sygn. I-III-12488, pismo gestapo w Grudziądzu z 12 I 1943. 
KOP having extended the structures of KOP in the territory subordinated to him.

What deserves special attention are Przybyła's external relations, which resulted mainly from his prewar political activity. He established in Torun contacts with the organization "Grunwald". He played there a very important function of courier and made frequent trips from Torun to Kutno and Poznań; he was also a courier of the Main Headquarters of KOP in Warsaw Major Marcel Cerklewicz alias "Bończa", who was the head of "Grunwald" in Torun' ${ }^{193}$. Przybyła also maintained contacts with various secret structures existing in Torun. What can be the evidence of Przybyła's fundamental function in KOP is the fact that in July 1940 he took part in a very important consultation taking part in the flat of Wacław Ciesielski alias "Roman" in Torun. Other participants of the meeting included: Major Józef Ratajczak alias "Englert", "Krauze", "Karolczak" - the first acting commander of the Pomeranian District Division of ZWZ, Captain Józef Chyliński alias "Bolesław" - the head of the staff of the Pomeranian District Division of ZWZ and Antoni Antczak alias "Adamski", "Ida" - the future Government Delegate for Pomerania ${ }^{194}$.

In the structures of KOP in Torun women played an important role. A shop assistant Zofia Jackowiak ${ }^{195}$ became a member of KOP. During the occupation period she lived at 7 Ogrodowa Street. She joined KOP, because she was Marian Tuszewski’s fiancée [the deputy

${ }^{193}$ A. Zakrzewska, Przybyła Adam..., p. 120.

${ }^{194}$ Wacław Ciesielski and Antoni Antczak from the spring of 1939 ran the underground activity. Originally, within "Grunwald" Ciesielski as the representative of the National Party [SN] headed the Administrative Department, while Antczak as the representative of the Labour Party [SP] was his deputy. The Department organized the helop for people under the threat of arrest and prepared the administrative personnel for the postwar period. After he started cooperation with ZWZ, Ciesielski was appointed the head of the Organizational Department of the Headquarters of the Pomeranian District Division of ZWZ. See: W. Grabowski, Polska tajna..., p. 50.

${ }^{195}$ Zofia Jackowiak, born o 11 April 1919 in Gnieszewo in the country of Tczew, Her father Marcin died in 1942 in the concentration camp in Stutthof, whilst her mother Anna nee Śliwińska lived in Torun at 7 Ogrodowa Street. After she passed her final secondary school examination 'matura', she worked for the Polish Red Cross and the Military Training for Women in Toruń. AMS, t. pers. Z. Jackowiak, sygn. I-III-6083, k. 1. 
commander of the Pomeranian District Division of KOP ${ }^{196}$. Also Witold Lendzion introduced his fiancée - Honorata Modrzyńska - to KOP. She was a courier between Torun and Warsaw. We know that she brought copies of the paper of KOP Polska Żyje from Warsaw along with money and the so called 'contributions of KOP', which were distributed among Poles in Pomerania. Originally, Modrzyńska travelled to Warsaw almost legally, using a Passierscheinen and a false ID card provided by Lendzion. It was not possible to establish the scope of work done for KOP by her sister Eugenia Modrzyńska, who set up in Bydgoszcz an organizational cell subordinated to her ${ }^{197}$.

Paweł Piątkowski at the end of October 1939 introduced his sister Jadwiga Pohl ${ }^{198}$ to the organization as her husband, who had been taking part in the war of 1939, had been captured and disappeared ${ }^{199}$. After she had been sworn in, she became his courier ${ }^{200}$. After Pawel Piątkowski left for Warsaw, she became subordinated to the commander of KOP in Toruń Reserve Lieutenant Alfons Zaborowski, with whom she stayed in touch. Her task was to take over the weapons provided by Zaborowskis brother, who was employed in the German ammunition warehouses ${ }^{201}$ in Torun. She also distributed the underground press, the paper of KOP Polska Żyje and collected money for organizational purposes transmitted to Torun by a courier. She delivered the money and the press to people living at the addresses indicated to her by her brother from Warsaw. She also travelled beyond Torun. In the winter of 1939-1940 she left for Łódź with an organi-

196 Such information was found in a letter written by an oficer of the Gestapo in Grudziądz, the senior criminal secretary Kohls to the commander of the concentration camp in Stutthof of 18 Nov 1942.AMS, t. pers. Z. Jackowiak, sygn. I-III-6083, k. 2.

${ }^{197}$ FGEZ, t. os. Lendzion W., List W. Lendziona do E. Zawackiej z 27 V 1981, sygn. M 393/1016 Pom., p. 2.

${ }^{198}$ Gertruda Jadwiga Piątkowska, born on 23 August 1914 in Toruń. In the years 19341937 she belonged to the Female Division of the Shooter's Association in Toruń, where she underwent the sanitary training. In 1937 she married Pohl. See: Relacje członków konspiracji pomorskiej w latach 1939-1945, wyb. i oprac. E. Kwiatkowska-Dybaś, Torun 2000, p. 158 , fn. 1.

${ }^{199}$ He was considered to be dead, so Jadwiga Pohl married Iwański.

${ }^{200}$ She did not have a codename.

${ }^{201}$ Jadwiga Pohl says in her account that she is not sure whether those were amunition warehouses or amunition plants. See: Relacje członków konspiracji..., p. 158. 
zational report and bullets ${ }^{202}$. It is only known that as part of her underground activity Pohl cooperated with Aleksa Szewa alias "Wera", a courier of KOP in Pomerelia. Szewa transported intelligence reports from Warsaw; she also brought to Torun instructions and guidelines for organizational work. She also ran the propaganda and charity activity $^{203}$. Pohl maintained contacts with Witold Lendzion and Berbard Domżalski ${ }^{204}$.

According to the sources, there existed links between members of KOP in Torun and members of Greater Poland's Military Organization. On 15 November 1939 Sub-Lieutenant of aviation Franciszek Dziarnowski alias "Głowacz" ${ }^{205}$ was sworn in by Kazimierz Staśkiewicz as part of Greater Poland's Military Organization (later known as the Military Organization of Western Territories) ${ }^{206}$. After he became a subordinate of the commander of WOW Captain Leon Kmiotek alias "Pomian", he originally took part in organizational works in Poznań. In his postwar account Dziarnowski described his contacts with members of KOP in Torun as follows (he failed to mention the name of the organization, though): "From November 1939 to March 1940 we received information that Lieutenant Geringer and Lieutenant Zaborowski (the former from the local infantry regiment and the

${ }^{202}$ Krótkie wspomnienie z tajnej działalności Gertrudy Jadwigi Iwańskiej na terenie Torunia w okresie od końca 1939 r. do marca 1940 r., [in:] Relacje członków konspiracji..., p. 158.

${ }^{203}$ FGEZ, Relacja A. Sobieralskiej-Szewy, sygn. K-45.

${ }^{204}$ After the war Bernard Domżalski lived in Rybaki Street in Torun.

${ }^{205}$ Franciszek Dziarnowski, born on 27 Sept 1910 in Krzemieniewo , the country of Lubawa. He did the military service graduating from the School for Reserve Officer Cadets of Infantry in Zambrów; having completed the training he was sent for apprenticeship in $1^{\text {st }}$ Ballooon battalion in Toruń. In the years 1934-1939 he lived in Grudziądz and was a member of the Association of Reserve Officers. He was mobilized on 25 August 1939 as reserve sub-lieutenant in $2^{\text {nd }}$ Balloon Copmany in Warsaw, where he held the function of the commander of the platoon. He was evacuated to the region of Łuck, was captured by the Soviets and imprisoned in Dubno. He escaped during the transportation and crossed the demarcation line heading for Poznań where his wife lived. See: FGEZ, akta F. Dziarnowskiego, sygn. V-225; ibid., sygn. I/10 Wojskowa Organizacja Ziem Zachodnich; M. Woźniak, Dziarnowski Alfons Franciszek ps. "Głowacz”, przybr. nazw. "Karol Szubert” (1910--1995), oficer WP, WOW-WOZZ, SBKP, cz. 3, Toruń 1997, pp. 51-52.

${ }^{206}$ More about WOW and WOZZ: M. Woźniak, Wojskowa Organizacja Ziem Zachodnich. Geneza - struktury - koncepcje - działalność (1940 r.), [in:] Pomorskie organizacje konspiracyjne poza AK 1939-1945, Toruń 1994, pp. 205-214. 
latter from the fire brigade) were in the process of setting up the underground organization. On my way to Warsaw, I visited the house of Lieutenant Zaborowski's fiancée (she was a friend of my sister's) and conversed with him. I expressed my doubts concerning the way the underground activity was organized. He confirmed that he kept a list of members of the organization (a few hundred people!). Naturally, I did not inform him about WOW and my organization. I only told him that I was going to Warsaw to learn about the issues connected with the military organizations. I do not remember whether he asked me to inform him about the effects of my penetrations in Warsaw. It is by all means possible that I mentioned WOW and Zaborowski's organization to Szczuka and Gelertówna ${ }^{207}$. After I left, the most pessimistic expectations came true. At the beginning of March there took place hundreds of arrests. Over ten days had passed before they captured me, from which I conclude that Zaborowski had managed to defend himself against revealing the data of the people involved in the underground activity (he had every right to think in this way about me). Undoubtedly, he was tortured. [...] It is obvious that the Germans captured me immediately after they had learnt my surname. It was on 19 March. Probably Mrs. Kuczyńska saved my life informing me about the Germans' presence. Myself and my sisters managed to take out all the materials and bring them to our uncle's daghters Maria and Alicja Dziarnowski, whose father and three brothers had been arrested before Christmas of 1939. I left Torun on 19 March 1940. Trapp ${ }^{208}$ was not arrested, while the remaining members of my five-person team were arrested after 5 March - I never saw them again. They might have been connected somehow with Geringer and Zaborowski"209.

${ }^{207}$ Szczuka (the first name unknown) was a son of a prewar publisher from Wąbrzeźno. Gelert was Dziarnowski's friend from Grudziądz. At the beginning of the occupation they both stayed in Warsaw, where they were members of ZWZ.

${ }^{208}$ Ferdynand Trapp , born on 31 Jan 1914, graduate of the gymnasium school in Starogard. Scouts' instructor in Toruń, scoutmaster in the years 1936-1937, the head of the Division of Senior Scouts in the Headquarters of the Pomeranian Standard of Scouts, mobilized in August 1939 as reserve officer cadet of the Polish Army, he took part in the war. See: A. Gąsiorowski, Szare Szeregi na Pomorzu 1939-1945, Toruń 1998, pp. 64-65.

${ }^{209}$ F. Dziarnowski, Głosy w dyskusji, [in:] Pomorskie organizacje konspiracyjne poza AK 1939-1945, Toruń 1994, pp. 270-271, 272. 
It seems that in Torun, where the Pomeranian structures of KOP were the most extensive, many members of KOP managed to avoid being arrested. On the basis of the available sources it is hard to state whether there was an attempt to reconstruct the cells of KOP or get in touch with the structures of KOP, which had not been crushed by the Gestapo during the liquidation action conducted in the autumn of 1940.

In Torun KOP got in touch with other underground organizations operating in the city. One may come across various pieces of information about the connections between KOP and the local organization the "Battalion of Death". T. Jaszowski described the "Battalion of Death" as follows: "This youth organization was the focus of interest of such officers as Waldemar Grienger ${ }^{210}$ and Alfons Zaborowski, who in the past helped to set up 'Grunwald'. Subsequently, they got in touch with the 'Corps of the Defenders of Poland', where they eventually stayed. At the turn of 1939 and 1940 it was too early to divide people into military units. (...) It was much later that organizational divisions and assignments to various political groups took place"211. It seems that Zaborowski and Geringer maintained closer contacts with the "Battalion of Death" since in the structures of KOP all over Poland it was expected to set up pillars for young people.

According to many accounts - both from the period of the occupation and postwar times - it may be concluded that at least a few people from the Headquarters of the Pomeranian District Division of KOP had been members of "Grunwald" - the organization set up on the basis of the prewar structures of the subversion beyond the frontline. Mutual relations between KOP and "Grunwald"- ZWZ have made it quite difficult to establish the structures of those organizations in Torun. The difficulties result from the fact that we are not familiar with all the important details of the organizational activity of "Grunwald" from the autumn of 1939 to the spring of 1940.

The following members of Witold Lendzion's family were very active in KOP: Lendzion's father Bolesław Lendzion residing in Torun,

${ }^{210}$ Error. On page 164 there was another error: Greinger. In fact, it was Lieutenant of the Polish Army Waldemar Geringer.

${ }^{211}$ T. Jaszowski, Gestapo w walce..., pp. 76-77. 
Lendzion's brother Jerzy Lendzion ${ }^{212}$ associated also with the "Battalion of Death" and the Gray Ranks. Not much is known about Lieutenant Bogdan Gawalski's connections with KOP. According to the postwar accounts, he dealt with "Grunwald" - particularly with Lieutenant Walerian Mańkowski, who remained in touch with Gawalski's wife - Stefania Gawalska. Gawalski was arrested on 6 March 1940 - on the same day as Zaborowski. He was transported along with Zaborowski, Geringer and leaders of the "Battalion of Death" to the Gestapo prison in Bydgoszcz, and next to Warsaw.

In Torun and the vicinities various cells of the intelligence service of KOP were set up relatively quickly. They were established according to the ternary numeral system. It is known that Wiesław Stremlau alias "Brzezina", who ran the intelligence of KOP in Pomerania, had a few subordinates in Torun - one of them being Maroszewski (the first name unknown). In his three-person team there were also Ignacy Tomczak alias "Zawisza" 13 and Jan Grossy. They mainly conducted the military intelligence activity in Torun and its vicinities ${ }^{214}$. The head of the intelligence of KOP in the Torun county was Stanisław Obiegałka alias "Poraj" ${ }^{215}$, who was subordinated directly to the head of the intelligence of the Pomeranian District Division of KOP Witold Lendzion. Obiegałka lived in Kończewice near Toruń, where he ran

${ }^{212}$ Scoutmaster Jerzy Lendzion (1910-1940), employed in the Community Savings Bank in Brodnica. In 1931 in Brodnica he set up the Circle of Senior Scouts under the name of Andrzej Małkowski - the first group of this kind in Pomerania, which was very active. From 1934 he was the deputy commander of the regiment of scouts in Brodnica. See: J. Jankowski, Harcerstwo Pomorza Gdańskiego i Kujaw 1911-1945, Toruń 1988, 84.

${ }^{213}$ Prior to the war Tomczak was a member of the Camp of Great Poland.

${ }^{214}$ AMS, rel. I. Tomczaka.

${ }^{215}$ Stanisław Obiegałka alias "Poraj", born on 28 Nov 1904 in Palędzie, the country of Poznań. In 1933 he graduated from the State School of Gardening in Poznań. Originally, he worked as a gardener in Poznań, where he was the founder and the first president of the Professional Association of Gardeners in Greater Poland; he contributed to the establishment of the Botanic garden in Poznań. In 1933 he took the post of a clerk in the Home Starosty in Toruń; next, he became the head of the nursery of decorative trees in Konczewice near Chełmża, where he lived with his family. From the autumn of 1939 he was a member of KOP. AMS, B. Obiegałka, O moich rodzicach (wspomnienie napisane w 30-tym roku po śmierci Matki),Warszawa-Grudziądz XII 1987, mps, s. 1-6; idem, O Ojcu śp. Stanisławie Obiegałce więźniu Gestapo w Grudziądzu (na podstawie listów do Matki Celiny w latach 1940-1942), mps, p. 8. 
a plant nursery of decorative trees. He maintained underground contacts with a medical doctor Zagierski from Chełmża ${ }^{216}$.

\section{The structures of KOP in other Pomeranian towns}

As has been already mentioned, KOP set up its structures in Brodnica. It was Jerzy Lendzion ${ }^{217}$ who established the cells of KOP in Brodnica. It is worth describing his activity since Lendzion before the war had been the commander of Brodnica's regiment of scouts. Supposedly, he got in touch with KOP via his brother Witold; as early as November or December 1939 he started setting up sites of KOP in Brodnica. He invited to KOP prewar instructors of scouts and senior scouts. It is known that at the turn of December 1939 and January 1940 there took place an organizational meeting of KOP in Brodnica in Przedzamcze street. Apart from Lendzion the meeting was attended by: the owner of the flat sub-scoutmaster Konrad Porada, subscoutmaster Ludwik Grzemski and scout Marian Sobociński - before the war a member of the club of radiotelegraph operators, who had his own radio station. Another person invited to KOP in Brodnica by Lendzion was Aleksander Kruszczyński ${ }^{218}$. The instructors introduced to KOP started to establish further contacts among Brodnica's scouts. In this way they prepared the grounds for a more extensive organizational activity within KOP. Sub-scoutmaster K.Porada swore in the Scout of the Rzeczpospolita Leszek Zdrojewski, who before the war had been a member of the Sodality of Our Lady and worked in a bar in Brodnica ${ }^{219}$, which allowed him to acquire information and to run a contact point. As it may be concluded, in Brodnica the instruc-

${ }^{216}$ FGEZ, t. os. Obiegałka S., sygn. M-185.

${ }^{217}$ Jerzy Lendzion (?-1940). Not much is known about his activity in the interwar period. He was a scouts' instructor in Torun, where he received the rank of sub-scoutmaster. He moved to Brodnica probably in 1930 and started working in the Community Savings Bank. His brother Witold introduced him to KOP in January 1940 to the organization of Brodnica's instructors and senior scouts. His activity did not last long as he was arrested on 18 March 1940. See: J. Jankowski, Harcerstwo Pomorza Gdańskiego..., s. 84; A. Gąsiorowski, Szare Szeregina Pomorzu 1939-1945, Toruń 1998, pp. 88, 89.

${ }^{218}$ Aleksander Kruszczyński before the war was a director of the Community savings Banks in Brodnica and the head of the Circle of Scouting Lovers.

${ }^{219}$ After Jerzy Lendzion was arrested, he contacted the Military Organization Lizard Union and acted there using the codename "Żołw" until he was arrested at the beginning 
tors of the Polish Scouting and Guiding Association along with senior scouts joined KOP.

In Tczew a powerful cell of KOP was established quite early. From the postwar accounts we know that contacts between Torun and Tczew within KOP were maintained by Zofia Jackowiak ${ }^{220}$. Supposedly, the commander of the Tczew seat of KOP was a teacher and scouts' instructor sub-scoutmaster Witold Kmiecik alias "Janusz"221. As a reserve sub-lieutenant of the Polish Army, he was called up in the spring of 1939 and took part in the fights in September 1939 in Volhynia, possibly as a soldier of the Border Protection Corps. After his return to Tczew, he got involved in the underground activity. In the underground group set up by Witold Kmiecik there were teachers Józef Klawikowski ${ }^{22}$ and Wilhelm Gajewski, while Witold's younger brother Hieronim Kmiecik ${ }^{223}$ became a courier in Tczew. Upon the order of his brother Witold he contacted Józef Klawikowski. Witold Kmiecik's elder brother - Czesław Kmiecik (born in 1910 in Świecie), before the

of 1943. Comp.: A. Gąsiorowski, Szare Szeregi..., p. 87; B. Chrzanowski, Związek Jaszczurczy i Narodowe Siły Zbrojne na Pomorzu 1939-1947, Toruń 1997,pp. 14, 38, 41-42 i in.

${ }^{220}$ K. Ciechanowski, Ruch oporu..., s. 88. Zob. Arch. KWMO Bydgoszcz, sygn. 257, t. 1, protokół przesłuchania I. Tomczaka, W. Stremlaua, A. Przybyły i AMS, Kol. K. C., rel. W. Lendziona.

${ }^{221}$ Witold Kmiecik, born on 31 Jan 1916. In 1921 he moved with his family to Tczew, where he attended the Primary School no. 2. In 1930 he started studying in the Teacher Training College in Wejherowo. He was a member of the Polish Scouting and Guiding Association [ZHP] both at school and in the college. After graduation, he returmed to Tczew and became a teacher in Primary School no. 2. He was still a member of ZHP and was promoted to the rank of sub-scoutmaster. During the occupation he worked in the construction of the highway and the new bridge in Knybawa. AMS, Rel. H. Kmiecika; Biblioteka Gdańska PAN, Ms sygn. 5157, Starszoharcerski Krąg Instruktorski "Jaszczurka”. Harcerze bohaterzy Hufca ZHP w Tczewie polegli i pomordowani w latach II wojny światowej 19391945, Tczew, 2 III 1975, p. 27.

${ }^{222}$ In 1940 Klawikowski was probably introduced to KOP by Władysław Pawłowicz - a railroad worker. After he lost touch with KOP, Klawikowski was the county commander of TOW "Gryf Pomorski” in Tczew. See: A. Gąsiorowski, K. Steyer, Tajna Organizacja Wojskowa “Gryf Pomorski”, Gdańsk 2010, p. 417.

${ }^{223}$ Hieronim Kmiecik, born on 29 July 1920 in Świecie nad Wisłą. Before the war he lived in Tczew and worked in the railway as an assistant of a clerk in the station in Zajączkowo. After the outbreak of the war he exported the mobilization files in the evacuation train. Through Pelplin-Laskowice-Grudziądz-Toruń- Warsaw he reached Siedlce, where the evacuated DOKP from Torun was kept. It was there that they burnt all the files before the Germans arrived. He came back to Tczew at the beginning of October 1939. 
war residing in Bydgoszcz, also became a member of KOP. During the occupation period he worked as an assistant to a railroad engineer. $\mathrm{He}$ worked as a courier and upon the order issued by Witold Kmiecik he transported instructions and underground press to Tczew, where he collected reports ${ }^{224}$.

Hieronim Kmiecik in October 1939 was sent by Arbeitsamt to do construction works of a new bridge in Knybawa. He worked there as a carpenter in a construction company Weiss \& Freitag. Next in the spring of 1940 he was sent to a construction company which was building a military airport near Malbork [Marienburg] in Królewo Malborskie (then Königsdorf). He worked there until 1944. He was not in Tczew, when the members of the Tczew cell of KOP were arrested. Witold Kmiecik maintained secret contacts with an elderly instructor of scouts. However, it is hard to say whether he invited him to join $\mathrm{KOP}^{225}$.

We also know that a railwayman Alojzy Socha was a member of KOP in Tczew. He used to put up Zofia Jackowiak alias "Jacek", who sometimes visited him. She met Socha through her relatives from Tczew. As a railwayman Socha was responsible for transporting the KOP press from Kutno and Warsaw to Pomerania. Thus, Jackowiak gave him contact addresses in those cities ${ }^{226}$.

Jackowiak left for Tczew also to distribute the KOP paper Polska Żyje. Jackowiak established contacts with Wanda Waligórzanka, a daughter of the landowner from Czarlin; she had met her before the war as a member of PWK in the camp in Garczyn. Jackowiak left several dozens of copies of Polska Żyje, which were later distributed. Waligórzanka introduced Jackowiak to the teacher Witold Kmiecik, at whose house she also left the press ${ }^{227}$.

What happened later to the members of KOP from Tczew is very interesting as some of them continued their activity after KOP had

${ }^{224}$ AMS, Rel. H. Kmiecika z 13 IX 1990.

${ }^{225}$ Hieronim Kmiecik only said only that it was a tall scoutmaster who spoke nasally, because before the war he had been operated on. He survived the war, but Kmiecik did not remember his name. AMS, Rel. H. Kmiecika z 13 IX 1990.

${ }^{226}$ FGEZ, t. os. Jackowiak Z., Relacja, sygn. K 157/157 Pom., p. 3.

227 Ibid. 
been liquidated by the Germans and the contact with the Main Headquarters of KOP in Warsaw had been lost. In 1940 Hieronim Kmiecik also became a member of the Military Organization Lizard Union.

The information about the structures of KOP in Chojnice was included in the materials collected by Bernard Szczęsny, who originally acted as a member of KOP. Describing the underground organizations in Chojnice during WWII he wrote: "The seventh organization ${ }^{228}$ was an intelligence group acting as part of the national organization - KOP. In the Chojnice group there worked: Maksymilian Rokita ${ }^{229}$, Franciszek Jeżewski ${ }^{230}$, Alojzy Marzejewski ${ }^{231}$, Bernard Szczęsny and Teofil Chrzanowski" "32 . According to Szczęsny, the structures of KOP in Chojnice were not set up until June $1940^{233}$. Some members of the Chojnice group did not even know the name of the organization, which might mean they did not take a vow to KOP. For example, B. Szczęsny in his memoirs wrote: "At the beginning of April 1940 Alojzy Marzejewski, with whom I worked in the penitentiary estate 'Igły' near Chojnice suggested that I should join the national organization. Despite the fact that I did not know much about it, I accepted the proposal without any reservations as it gave me the opportunity to fight with the Germans. (...) Our main aim was to conduct the intelligence activity"234.

According to Szczęsny, the organizer and actual head of the KOP cell in Chojnice was Alojzy Marzejewski. He recruited Maksymilian Rokita and Franciszek Jeżewski. Maksymilian Rokita maintained contacts with Wiesław Stremlau from Torun through A. Marzejew-

${ }^{228}$ Working in the area of Chojnice.

${ }^{229}$ Maksymilian Rokita, born on 4 Jan 1914 in Karsino, the country of Chojnice.

${ }^{230}$ Franciszek Jeżewski, born on 9 Oct 1902 in Wiele, the county of Chojnice. Before 1939 he worked as an instructor of the Military Training, next in the Polish Railaway [PKP] in the station of Chojnice.

${ }^{231}$ Alojzy Marzejewski, born on 12 April 1923 in Chojnice.

${ }^{232}$ FGEZ, t. os. Szczęsny B., B. Szczęsny, Organizacja ruchu oporu w powiecie chojnickim w latach 1939-1945, mps, b.d., sygn. M 421/1047, p. 26.

${ }^{233}$ Ibid.

${ }^{234}$ Ibid., on page 124 Skerska says that having been arrested in October 1942 Bernard Szczęsny was imprisoned in the concentration camp in Stutthof, where he met Rokita, also arrested in 1940. He learnt from him that they both belonged to the same organization KOP. 
ski and his brother Joachimczyk residing in Toruń. Szczęsny thinks that Stremlau received the vow from Rokita in the presence of Tomczyk and "could recognize him as the head of the Chojnice group" 235 . Szczęsny writes about it: "In reality and in practice it looked different. Only Marzejewski stayed in touch with the headquarters in Toruń; he was the person to assign tasks and collect materials, which he sent to Toruń. Marzejewski knew all the members and contacted everybody, while Rokita did not know about Franciszek Jeżewski’s work for KOP, and the other way round - Jeżewski did not know about Rokita's work" ${ }^{236}$.

After losing touch with the Headquarters of the Pomeranian District Division of KOP in Torun members of the KOP seat in Chojnice in March 1941 were incorporated to ZWZ [the Union of Armed Struggle] by the scoutmaster Bernard Mysliwka alias "Konrad". Bernard Szczęsny alias "Beno", "Jan", "Szulc" became the commander of ZWZ Chojnice under the cryptonym "Bele", "BOG5", which embraced the town and county of Chojnice. Franciszek Jeżewski set up ZW-AK in the region of Wiele, Brusy and Męcikał. Marzejewski, sworn in also in March 1941 had the role of the head of the intelligence service in the Headquarters of the District of ZWZ-AK Chojnice. After Szczęsny had been arrested on 15 October 1942, Marzejewski and Jeżewski continued working for AK [ Home Army] $]^{237}$.

We also have information about KOP in Chojnice from preserved German documents. It may be inferred from the documents that from at least August 1940 Maksymilian Rokita, a builder residing in Chojnice at 4 Post-Stallstrasse remained in touch with KOP. The Gestapo only managed to establish that in the years 1937-1938 he had served in the Polish army, and shortly before the outbreak of the war he had been called up to the National Defence ${ }^{238}$.

We did not manage to establish the circumstances of the creation of all the structures of KOP in Pomerania. There is still lack of data about some cells of KOP. Probably KOP had its seats also in Kościerzyna

\footnotetext{
${ }^{235}$ FGEZ, t. os. Szczęsny B., sygn. M 421/1047, s. 6.

${ }^{236}$ Ibid.

${ }^{237}$ FGEZ, t. os. Szczęsny B., Relacja, sygn. M 421/1047, pp. 14-15.

${ }^{238}$ AMS, KLS, t. pers. M. Rokity, sygn. I-III-13014, k. 3.
} 
and the county of Kościerzyna. We know that Stanisław Lesikowski alias "Las", having been mobilized and having left Pomerania to defend Warsaw, remained in hiding after Warsaw had been taken over. In January 1940 in Platerów he probably got in touch with KOP (although supposedly it was SZP transformed into ZWZ). He was promoted to the rank of captain (organizational rank); in mid-1940 he returned to Kościerzyna and started to set up the underground network. Still, not much information exists about his activity in this period. Supposedly, he lost touch with KOP due to the arrests among KOP members and in the first half of 1941 he joined the Polish Army of Resurrection [PAP] taking the position of the commander of the Koscierzyna Region ${ }^{239}$.

In March 1940 Alojzy Jędrzejewski alias "Jawor" established contacts with KOP. He participated in the fights in September 1939 in the Battalion of the National Defence "Kościerzyna". After he returned to Pomerania, he was employed as a railwayman in the train station Bąk in the county of Kościerzyna; he contacted the underground organization created by the priest Wrycza, later on subordinated to "Gryf Pomorski". In his postwar account he stated generally that he had established contacts with KOP through Lieutenant Paweł Piątkowski alias "Major Pokrzywka" ${ }^{40}$ and Jan Saldat alias "Dzwon". This is how he described this moment: " > Major Pokrzywka<< listened to the vow from me in the flat of the standard-bearer Jan Saldat alias ' $\mathrm{Dz}$ won' in Stara Kiszewa. It was there that I received an order to organize a relay: Kościerzyna-Czersk-Karsin-Wiele- Kościerzyna. My next task was to look for, get out, preserve and distribute the weapon hidden near the forester house of Okoniny by the withdrawing units of the Polish army in 1939. Major Pokrzywka prepared the mobilization plan in case of the victorious offensive of the French army. I was then appointed the commander of the company the soldiers of which

239 See: B. Chrzanowski, Stanisław Lesikowski (1906-1944) działacz organizacji podziemnej Polska Armia Powstania i Armii Krajowej, [in:] Zasłużeni Pomorzanie w latach II wojny światowej. Szkice biograficzne, Wrocław 1984, s. 135-137; idem, Lesikowski Stanisław ps. "Las" (1906-1944), kmdt Okręgu Kościerskiego PAP i Obw. Kościerzyna AK, SBKP, cz. 3, Torun 1997, pp. 109-111 (there is a supposition that his contact with KOP might have taken place as early as October 1939).

${ }^{240}$ This codename does not appear in any other source. 
were to be recruited from the area of Konarzyny, Olpuch, Bartoszylas, Wygon and Chwarzno. At the beginning of the possible action I was to disable local Germans, to man the railway station Bąk and Olpuch long with the mills in Wojtal and Ruda and the junction of the roads near Stara Kiszewa. I was to bring along the rest of the company to Kościerzyna. However, after the defeat of France the plan was invalid. After 'Major Pokrzywka" was arrested by the Gestapo, our group again became subordinated to "Gryf"' 241 . After some time, Jędrzejewski got in touch with Stanisław Lesikowski alias "Las" and worked with him in the Polish Army of Resurrection, later in the Home Army until the end of the war $^{242}$.

Supposedly, the structures of KOP were also established in Starogard. Now it is hard to state whether a railwayman Franciszek Izydor Broza acted there as a member of KOP. We only know that during the occupation he belonged to the group of railwaymen from Starogard, who organized sabotage in the trains ${ }^{243}$.

In fact, only one account and testimony provided by Borucki confirms that the Pomeranian District Division of KOP set up its cells in Gdańsk. The commander of the district, Paweł Piątkowski, probably used to go to Gdańsk himself. It is hard to state whom he contacted in Gdańsk as he did not reveal it during the interrogation. From the preserved documents and other sources we know that no inhabitant of Gdańsk was arrested during the liquidation action of KOP in 1940. We may only suppose that KOP got in touch with a Polish railwayman Alfons Lendzion - Witold Lendzion's relative, born and bred in Gdańsk. It is possible that Alfons Lendzion contacted KOP in another way as early as October 1939 in Kutno, where he found himself in September 1939 after leaving Gdańsk and Gdynia ${ }^{244}$.

${ }^{241}$ Relacja Alojzego Jędrzejewskiego o jego udziale w pracach konspiracyjnych różnych organizacji podziemnych na terenie Pomorza w latach 1939-1945, [w:] Relacje członków konspiracji pomorskiej w latach 1939-1945, Toruń 2000, p. 144.

${ }^{242}$ A. Gąsiorowski, Jędrzejewski Alojzy ps. "Andrzej”, "Jawor” (1911-...), szef łączności Insp. AK Tczewsko-Chojnickiego, SBKP, cz. 1, Toruń 1994, pp. 101-102.

${ }^{243}$ AMS, Wspomnienia, t. III, Henryk Trepczyk, Fakty i zdarzenia okresu międzywojennego. Kolejarze - ofiary wojny i masowych morderstw, p. 263.

${ }^{244}$ See more: A. Gąsiorowski, Polska Armia Powstania. Największa tajemnica pomorskiej konspiracji, Toruń 1997, pp. 51-52, 71, 87, 92, 108. 
It seems that $\mathrm{KOP}$ at the beginning of its existence set up its structures also in Gdynia. However, the information is not confirmed by the sources and postwar accounts. We must remember that in Gdynia from October 1939 there took place mass relocations of Poles to the General Government, which affected dozens of thousands of people. Thus, the beginnings of the underground movement in Gdynia have not been examined yet. We may only suppose that Captain Jan Jarzębowski alias "Okoń" joined KOP. Before the war he had been an officer of the Border Protection Corps, and from 1937 he was an officer of the City Headqaurters of WF and PW, supposedly as an officer of the subversion beyond the frontline. He took part in the defence of Gdynia as the commander of the $3^{\text {rd }}$ company of I Gdynia Battalion of $\mathrm{ON}^{245}$. The postwar literature confirms the existence of underground structures of KOP in Gdynia, but without any details ${ }^{246}$. It is probable that Piotr Hulewicz alias "Jastrząb" acted as a member of KOP in Gdynia. He seems to have been trained in the subversion beyond the frontline; in August 1939 he was called up and took part in the war. He finished fighting as a soldier of the Operation Group "Polesie" of General Franciszek Kleeberg, which included the group of the Border Protection Corps. Probably it was then that he joined the secret resistance movement. He returned to Gdynia in October-November 1939. From his postwar accounts we know that originally he maintained contacts with the organization "Grunwald" or KOP ${ }^{247}$. The evidence of the fact that he was only indirectly associated with KOP is his incorporation into the Polish Army of Resurrection [PAP] and becoming the commander of the Gdynia Region of PAP. He maintained contact with Reserve Lieutenant of the Polish Army Sergiusz Kostecki alias "Czarny", who had joined KOP much earlier ${ }^{248}$.

${ }^{245}$ Gdynia 1939. Relacje uczestników walk lądowych, wstęp - wybór - komentarze W. Tym, A. Rzepniewski, Gdańsk 1979, s. 56, 94, 223, 233 i in.

${ }^{246}$ See: A. Kazimierczak, O gdyńskim ruchu oporu $w$ latach hitlerowskiej okupacji, Jantarowe Wici, 1976, nr 12, s. 33. The author writes there that during the occuaption period KOP was the only organization that operated in Gdynia.

${ }^{247}$ It is hard to confirm his connections with KOP in this period owing to a lack of information about it in the postwar accounts.

${ }^{248}$ A. Gąsiorowski, Hulewicz Piotr ps. "Jastrząb" (1913-1955), kmdt Rejonu Gdyńskiego PAP, następnie Okręgu Morskiego PAP w Gdyni, SBKP, cz. 3, Toruń 1994, pp. 69-71. 
Chapter III

\section{THE MAIN ACTIVITY SPHERES OF THE POMERANIAN DISTRICT DIVISION OF THE HEADQUARTERS OF THE DEFENDERS OF POLAND}

\section{Contacts in Warsaw}

The available accounts do not make it possible to describe the activities of the Pomeranian District Division of KOP in its totality. Both the post-war reports and the few preserved documents of the organization allow us to recreate only the guidelines for KOP work, in force for the whole organization. It is, however, impossible to determine now which of these guidelines were implemented in Pomerania and to what extent. It is known that in this territory the predominant tasks were - as in other areas of Poland where KOP had its structures - intelligence, anti-German propaganda, various charity actions and organization of contacts with the General Government [GG] as well as translocation from Pomerania to the GG the Poles sought by the Gestapo and the KOP members in danger of being arrested.

The charity work of KOP particularly deserves attention, as it was organized both at the central level in Warsaw and in the local branches of KOP. It reached quite a wide range of people, primarily Polish prisoners of different camps and their families. It is difficult to say now to what extent this was done to provide real help, and to what extent it was to conceal activities of different people and provide cover for the basic work of KOP in the case of exposure. Certainly it facilitated hid- 
ing the real aims of the organization, both from people loosely connected to KOP and the Gestapo officers ${ }^{249}$.

In Warsaw the person involved in organizing charity actions destined for Pomerania was Maria Bołtuć, the widow of General Mikołaj Bołtuć, the commander of the 4th Infantry Division, who died during the defensive war of 1939. Under the codenames "Marianna" and "Mutka", she was the liaison of both "Grunwald" and KOP in Warsaw. Charity work was also done in Pomeranian towns where KOP had established their branches. Aleksa Szewa, a Toruń subordinate of Paweł Piątkowski, mentioned charity activities of KOP in Pomerania in very general terms: "Financial support was given to the widows of the fallen and to the families of the prisoners of war or those crippled in the war" ${ }^{250}$. Within the Pomeranian District Division of the KOP charity activities were carried out in Kujawy [Kuyavia], particularly in the sub-district of Nieszawa. This action involved also people belonging to the so-called Free Outposts of the Defenders of Poland [Wolnych Placówek Obrońców Polski], formed by KOP members from their most trusted people who, however, were not KOP members. This charity action covered mostly prisoners of war and their families, families of persons killed or arrested, and people who were ill or held in prison. Within the framework of this action, help was provided to Jews from a ghetto established in Ciechocinek ${ }^{251}$. Also, in Aleksandrów and Ciechocinek were created secret accommodations, where people threatened with arrest could hide before they were smuggled across the border to the General Government. In those places were also secret depots, where ammunition, grenades and explosives were stored $^{252}$.

From the beginning attempts were made to provide financing which the organization needed for different forms of its activities. The main source were contributions from KOP members and supporters.

${ }^{249}$ A. Gąsiorowski, Geneza i początki ruchu oporu na Pomorzu Gdańskim, Gdańsk 1991, p. 87.

${ }^{250}$ AMS, Ankieta A. Serwy z 20 X 1974.

${ }^{251}$ B. Ziółkowski, Kujawski Związek Polityczno-Literacki i Kujawskie Stowarzyszenie Społeczno-Literackie na Kujawach Wschodnich w latach okupacji niemieckiej 1939-1945 (Działalność i losy konspiratorów), Toruń 2006, p. 97.

${ }^{252}$ Ibid. 
With that aim, KOP donation certificates were distributed. Attempts were also made to utilize any chances to fill the treasury of the Pomeranian District Division of KOP ${ }^{253}$.

Intelligence and counterintelligence were probably among the best developed forms of activity during the first period of the existence of KOP. A document from the Łódź Gestapo, based on data coming from "an important officer of Polish resistance organization KOP (Defenders of Poland)", in its special part concerning particular organizations discusses in very general terms the contacts of the commander-in chief of KOP Henryk Borucki with the Musketeers ${ }^{254}$. Its conclusion is that at the beginning of 1942 Borucki established contacts with the Musketeers through "Ruszczyc", and this connection was upheld by "Brand" and "Roman". According to its brief characterization included in that document, the Musketeers "dealt mainly with communications (and intelligence)" and it had "also their agencies in the Reich" 255.

The post-war testimony of Henryk Borucki, codename "Czarny", since the spring of 1940 the commander-in-chief of KOP, informs that during interrogations at the Gestapo he was confronted with people linked to Pomerania: Paweł Piątkowski and doctor Wasilewski. Borucki stated: "Doctor Wasilewski, I don't know his name. During the occupation - in Żoliborz, I don't know the detailed address. A member of KOP, cooperating with "Bończa" Cyrklewicz. Wasilewski was arrested I don't know exactly when by the Gestapo. I know of his arrest as at the beginning of 1941 I was confronted with him in the Aleja Szucha about contacts with a certain "Engineer - Stefan Witkowski, the head of the group of the »Musketeers«. About that matter I was also confronted with a KOP member, the head of intelligence for the area of the Reich, Paweł Piątkowski, and with the wife of major Kuśmierek" ${ }^{256}$.

Directly involved in intelligence activity, the commandant of the Pomeranian District Division of KOP Paweł Piątkowski maintained in Warsaw contacts with the officers from the Pomeranian district

\footnotetext{
${ }^{253}$ AMS, Kol. K. C., Notatka z relacji W. Lendziona z 16 XI 1965.

${ }^{254}$ In the document the organization was referred to as ' 3 Musketeers'

${ }^{255}$ IPN BU, sygn. 0-330/246, t. 1, k. 57.

${ }^{256}$ IPN BU, sygn. 0330/246, t. 5, k. 32.
} 
Headquarters of the ZWZ [Union of Armed Struggle] who were staying there. At one of the contact points he had meetings with Captain Józef Gruss, codename "Stanisław", the head of intelligence in the Pomeranian District Division of ZWZ. The post-war account of Gruss reveals that during those meetings Piątkowski used the codename "Podchorążak" ["Cadet"] 257.

There are basically no reports regarding the intelligence contacts of Paweł Piątkowski with engineer Stefan Witkowski, the head of the intelligence organization "Musketeers", mentioned by Borucki. The dispatches from the territory of the Reich and the Western Polish lands annexed into the Reich, including Pomerania, which the "Musketeers" received at the beginnings of the occupation, were mentioned after the war in quite general terms by Kazimierz Leski, codenames "37" and "Bradl", who from the autumn of 1939 worked on establishing the communication intelligence network for the Musketeers. It was characteristic that the information drop points for the Reich created within the Musketeer network bore the codename "The Pomeranian". Leski mentions that there were two such points; "The Pomeranian 1" drop point was located at 15 Kossaka St., the bell on the left, in the flat of the wife of an intelligence officer Kuśmierek, who at that time was in an oflag. This contact point was eliminated in 1941 by the arrest of the wife, the painter Aniela. "The Pomeranian 2" drop point was designated for liaisons from Torun, and located probably at 10 Chopina St. ${ }^{258}$

Slightly more information on that matter can be found in the postwar testimony of the commander-in-chief of KOP Henryk Borucki. He mentions several times the intelligence contacts with the "Musketeers" maintained in Warsaw by Paweł Piątkowski. First it must be stressed that Borucki described Piatkowski as "the head of the KOP intelligence for the Reich territory". According to Borucki, engineer Witkowski, who was the leader of the intelligence organization Musketeers, had meetings with Paweł Piatkowski in Żoliborz at 15 Kossaka

${ }^{257}$ AMS, Materiały Drygałowej (copy).

${ }^{258}$ K. Leski, Życie niewłaściwie urozmaicone. Wspomnienia oficera wywiadu i kontrwywiadu AK, wyd. I, Warszawa 1989, p. 81. 
St. in the flat of Mrs Kuśmierek, a wife of a major in the Polish Army ${ }^{259}$. Borucki testified about those intelligence contacts of Piątkowski and Witkowski only several days after his arrest by the Soviet special services $^{260}$. From the data provided by Borucki after the war one may conclude that Borucki probably did not know much about Piątkowski, as he stated that Piątkowski "just visited at Mrs Kuśmierek, while he permanently stayed in the Reich" ${ }^{261}$. According to Borucki, Piątkowski - on the orders of Wincenty Daremniak, codename "Brzoza" - passed intelligence information to Witkowski knowing that he was an officer of the Intelligence Service sent from London ${ }^{262}$.

The information contained in the extensive report on intelligence and counterintelligence created by Borucki in prison after the war sounds quite enigmatic ${ }^{263}$. It mentions that in the spring of 1940 a member of the British intelligence network was arrested in Warsaw. In his flat, which after a superficial search was sealed by the Gestapo, in hidden caches still remained valuable documents. Borucki was informed about this by Lt.-Col. Marceli Cerklewicz, codename "Bończa", and Mieczysław Wieczorkiewicz, who got Borucki in touch with "the representatives of certain Intelligence Service cell operating in Pomerania, to deal with this issue". Those valuable hidden materials supposedly included blank German border passes, identity cards and the seal of the Police Headquarters in Torun. Collecting these documents before the second search of the flat by the Gestapo was of utmost importance, as it would protect "hundreds of Poles who using those [...] documents remained in Pomerania." There was no possibility to warn them quickly of the threat. Borucki was asked to use KOP members to carry out this action ${ }^{264}$. KOP received a certain sum in gold dollars for completing this task. Now it is known that the action described above by Borucki took place after the arrest in March 1940 of Eugeniusz En-

${ }^{259}$ IPN BU, sygn. 0330/246, t. 5, k. 32.

${ }^{260}$ Ibid., t. 2, k. 11.

${ }^{261}$ Ibid., k. 37.

${ }^{262}$ Ibid.

${ }^{263}$ The treatise was titled: Wywiad i kontrwywiad na terenie Polski w okresie 19391945 [Intelligence and counterintelligence in Poland in the period 1939-1945.]

${ }^{264}$ IPN BU, sygn. 0330/246, t. 2, k. 155 
gler, the head of the legalization section of "Grunwald", and not - as Borucki wrote - a member of British intelligence ${ }^{265}$.

2. The intelligence activities of the Pomeranian District Division of KOP

In Pomerania intelligence tasks were from the start one of the main forms of KOP activity. The account of Witold Lendzion states that in the mid-October of 1939 in Torun, in the flat of his then fiancee Honorata Modrzyńska took place the first meeting of the intelligence section created within the Pomeranian District Division of KOP. Witold Lendzion thus described its personnel and functioning: "It included the District Comm[andant] Pawel Piątkowski, Marian Tuszyński, Zofia Jackowiak, Honorata Modrzyńska and Witold Lendzion. All the members of the group usually received the tasks they proposed. Among others, Honorata analyzed the Nazi crimes committed in retaliation for the so-called Bloody Sunday. The cell of five worked in this shape for three months. In the middle of December 1939 I was called to Warsaw for a meeting with the national leaders of KOP intelligence, first with "Mrs Colonel" (contact points 27 Złota St at Mrs Burdyńska's and at a villa in Żoliborz) and then with the "Engineer" (Narbutta St.) where I received a formal nomination to the head of the intelligence for Eastern Pomerania. Then the contacts and the organizational structure changed. Wiesław Stremlau joined the five, we broke the contacts with Zaborowski, and the scope of Piątkowskis function was limited to the emergency contact - solely with me and only in Warsaw, which Piątkowski did not leave again until his arrest (at the end of October 1940). From then on also Honorata had two important functions: a) she maintained contacts with Franz Pansramm, the secretary of the Selbstschutz commandant Zapporowitz (...); and b) as the only intelligence liaison with Warsaw she organized her own places for crossing the border" ${ }^{266}$.

${ }^{265}$ Zob. Wiśniewski M., Z historii powstania i działalności Komendy Obrońców Polski, Wojskowy Przegląd Historyczny, 1967, nr 3, p. 243.

${ }^{266}$ FGEZ, t. os. Modrzyńska H. zam. Lendzion, List W. Lendziona do E. Zawackiej z 12 VII 1981, sygn. K 524/524 Pom. 
It was a clear success of KOP to get a German from Torun Franz Pansramm, a secretary of the Selbstschutz commander for the city and county of Torun, to cooperate with couterintelligence, predominantly because in the beginning in Pomerania Selbstschutz - together with the security police - played the leading role in organizing various repressions towards Polish inhabitants. Besides, the members of this organization, formed from the Pomeranian Germans, not only pointed out the Poles with anti-German attitudes and participated in making lists of Poles considered dangerous, but also took part in arrests and mass executions in Pomeranian forests. Therefore information obtained from Pansramm was very valuable. Among other things, Pansramm handed the intelligence head of the Pomeranian KOP Witold Lendzion lists of names of persons who were to be arrested for their anti-German activity before the war or because of suspected underground activities during the war ${ }^{267}$. Organizing intelligence and counterintelligence structures first resulted not only from the necessity of providing Warsaw with important information, but - above all - from the need to ensure the organization's security by early detection of actions against KOP and other Polish organizations undertaken by German police structures.

From the beginning of KOP's operations in Pomerania, various data were systematically collected. KOP members were interested not only in military intelligence, i.e. location of German military units and movements of German armed forces in Pomerania, but they also obtained current information on the police forces stationed in Pomerania. They also tried to gather all the data regarding the current socioeconomic situation in Pomerania and conducted first attitude checks among the Polish citizens. They also collected all the information on the crimes committed in this area by Germans, and on the scope of police terror and its effects. The leader cells of the Pomeranian KOP intelligence carried out initial analysis of the intelligence material gathered by KOP members, before sending reports to the KOP HQ in Warsaw. For example it is known that Stanisław Obiegałka, codename "Poraj", documented the current developments in the economic

${ }^{267}$ AMS, sygn. Z-II-4-1. 
situation of Pomerania and passed the reports he wrote to Wiesław Stremlau, who took them to Warsaw ${ }^{268}$.

Adam Przybyła, codename "Stefan Bywalec", right after being sworn in as a KOP member in November 1939 set about collecting various intelligence data. He looked for informers in the German military forces, found out the numbers of German military units stationed in Torun and in whole Pomerania, and obtained news about German military transport passing through Pomerania. He was also interested in all data on German crimes committed against the Polish population in Torun and in the south of Pomerania. After assuming the position of the district commandant of KOP, Przybyła maintained close intelligence and counterintelligence contacts with Marian Tuszewski, the head of the Pomeranian KOP intelligence ${ }^{269}$. In July 1940 Przybyla received from the carpenter J. Nowak information about the camp for British prisoners of war in Torun forts in Rudak. Przybyła passed information from this source to the KOP HQ through a courier, Władysław Jędrzejewski ${ }^{27}$. In a letter from the Grudziądz Gestapo to the command of the Stutthof camp - where Adam Przybyła was imprisoned after investigation - we can read that as the KOP district commander Przybyła included in the organization a large number of members who systematically provided him with military and economic intelligence information.

It is known that Zofia Jackowska from Torun became involved in intelligence activities. Her function was the liaison for Witold Lendzion and Marian Tuszyński, codename "Czarny". For intelligence purposes she made trips from Torun to Tczew, where she met with a railwayman Alojzy Socha. She recalled those events: "Distribution trips were combined with intelligence jaunts. I got from Socha information about the movement of ships on the Vistula, about railway transports between Gdańsk and Tczew (I carried partially coded sheets from him to Lendzion, often without knowing their content)"271. It is certain that

${ }^{268}$ Ibid.

${ }^{269}$ A. Zakrzewska, Przybyła Adam przybr. nazw. "Stefan Bywalec" (1907-1985), kmdt. Rejonowy KOP-Toruń, SBKP, cz. 4, Toruń 1998, p. 120.

${ }^{270}$ A. Zakrzewska, Przybyła Adam..., p. 121.

${ }^{271}$ FGEZ, t. os. Jackowiak Z., Relacje, sygn. K 157/157 Pom. 
intelligence data came from all KOP members, no matter whether they were part of the intelligence or worked in other structures.

After the first arrests in Torun in March 1940 Witold Lendzion brought to KOP Kazimiera Jackowska. He described this in 1981: "She was brought into the organization by me (after the first arrest), when I hid in the house where she lived. Through her, I got in touch with Tuszewski, Stremlau and others many times when I visited from Warsaw" ${ }^{272}$.

In Grudziądz existed a local organization "Rota”, led by Tadeusz Kaube, established as early as 1939. It is known that a member of Grudziądz "Rota" Michał Kwiatkowski had connections with Witold Lendzion and the intelligence of the Pomeranian District Division of KOP. However, it was impossible to establish in what circumstances they got in touch and what was the scope of their cooperation ${ }^{273}$.

The KOP members from Chojnice were involved in intelligence activities as well. The members of this group collected materials mostly related to the German military units stationed in that town or passing through Chojnice. They also prepared a report on the system of cable connections between Berlin and Królewiec [Königsberg], and made lists of Germans participating in murders of Polish citizens. Intelligence reports were taken by F. Jeżewski and other railwaymen to Toruń $^{274}$.

In his memoirs, Bernard Szczęsny describes the division of tasks between the individual members of the KOP branch in Chojnice: "M. Rokita - military intelligence; A. Marzejewski - matters related to the activities of the Gestapo, gendarmerie, SS and SA; F. Jeżewski - intelligence at Chojnice railway station (military transport and smuggling materials from Chojnice to Toruń); B. Szczęsny - political and social intelligence" 275 . From his memoirs one can also recreate at least some tasks performed by the KOP members in Chojnice. They were quite

${ }^{272}$ FGEZ, t. os. Lendzion W., List W. Lendziona do E. Zawackiej z 27.05.1981, sygn. M 393/1016 Pom., pp. 1-2.

${ }^{273}$ T. Jaszowski, Gestapo w walce z ruchem oporu nad Wisła i Brdą, współpraca autorska: W. Jastrzębski, Bydgoszcz 1989, p. 53.

${ }^{274}$ FGEZ, t. os. Szczęsny B., B. Szczęsny, Organizacja ruchu oporu w powiecie chojnickim w latach 1939-1945, mps b.d., sygn. M 421/1047, p. 26.

${ }^{275}$ Ibid., Relacja, p. 6. 
varied. Szczęsny writes: “The more important tasks I performed and prepared included: a report on the extermination of Poles by Nazis during the first months of the occupation in the autumn 1939 and spring 1940 , with a detailed list of the places of mass execution, names of the participating members of the Selbstschutz, gendarmerie and Gestapo, and the approximate number of the executed persons; a report on the moods among the German population, subdivided into the members of the older and the younger generation living in the county versus the Germans resettled from the Reich and Gdańsk; a report on the leading officers of the Nazi party NSDAP and administration. Besides these comprehensive reports, there was a number of smaller tasks ${ }^{276}$.

The members of this group collected materials mostly related to the German military units stationed in that town or passing through Chojnice. They also prepared a report on the system of cable connections between Berlin and Królewiec [Königsberg], and made lists of Germans participating in murders of Polish citizens. Intelligence reports were taken by F. Jeżewski and other railwaymen to Torunn ${ }^{277}$.

\section{The propaganda and information activities of the Pomeranian District Division of KOP}

Due to the lack of sources, it is difficult nowadays to describe all the activities of the Pomeranian District Division of KOP. It is known, however, that from the start anti-German propaganda and information were one of the most important spheres of the activity of the entire KOP; this is also relevant with regard to Pomerania. This type of propaganda was particularly significant in Pomerania, where the Polish society from the beginning had been deprived of Polish press and Polish cultural institutions, and were subjected to the immense pressure of German propaganda. Libraries, theatres and educational societies and organizations were disbanded. Also the increasing insistence on Germanization and the fact that local authorities prohibited the use of Polish language demoralized a certain part of the Polish

${ }^{276}$ Ibid., p. 7.

${ }^{277}$ FGEZ, t. os. Szczęsny B., B. Szczęsny, Organizacja ruchu oporu w powiecie chojnickim w latach 1939-1945, mps b.d., sygn. M 421/1047, p. 26. 
population in Pomerania. The German authorities in Pomerania did not use Polish even for propaganda purposes ${ }^{27}$. Single copies of the Polish-language newspapers Goniec Krakowski and Nowy Kurier Warszawski published in the General Government were delivered to Pomerania only on a very limited scale and only until May $1941^{279}$. Already during the first days after the invasion of the area by German troops, an order was issued to immediately hand over all the radio sets that belonged to the Poles, ostensibly for safekeeping. Many Pomeranians obeyed the order, afraid of repercussions, so a large part of the Polish population in Pomerania was basically deprived of any access to the information on the real course of the war and on Polish matters. Also the Danzig-West Prussia district established here became isolated from the rest of the country through creation of a police-patrolled border with the General Government; as a result, it was increasingly difficult to deliver the underground magazines published in GG; thus supplying such publications to Pomerania was of such great importance. The underground papers and magazines distributed there were a proof of connection between Pomerania and the remaining part of occupied Poland. Therefore the propaganda part of the activities of the Pomeranian District Division of KOP was so significant.

Many reports show that KOP - published magazine Polska Żyje [Poland Lives] reached Pomerania through two main channels. The majority was brought in by different KOP liaisons, mostly railwaymen, but also by sailors on the Vistula ships ${ }^{280}$. The KOP publication Polska Żyje was particularly widely distributed in Pomerania until the autumn of 1940, when the Gestapo destroyed the structures of the Pomeranian District Division of KOP. Later the magazine reached Pomerania occasionally, not through permanent and organized system of distribution ${ }^{281}$.

Polska Żyje published a variety of information concerning Pomerania, part of which was certainly provided by the members of the Po-

${ }^{278}$ Only posters informing about death sentences for Poles were in Polish.

${ }^{279}$ K. K. Ciechanowscy, Tajna działalność kulturalno-oświatowa na Pomorzu w latach 1939-1945, Gdańsk 1975, pp. 13-14.

${ }^{280}$ Zob. K. K. Ciechanowscy, op.cit., p. 88.

${ }^{281}$ Ibid. 
meranian District Division of KOP. From the start of the occupation, the magazine tried to provide morale-boosting information ${ }^{282}$.

In the first reports from Pomerania, Polska Żyje informed about mass crimes committed in this territory by Germans. The articles stressed that the victims were mainly the representatives of Polish intelligentsia. As early as in December 1939, when citing the examples of murders in Gdynia, Bydgoszcz and Torun, they stated in quite general terms: "In all the Polish lands occupied by Germans, and particularly in the territories annexed into the Reich, dreadful terror still runs rampant" ${ }^{283}$. This was accompanied by the information that in Bydgoszcz "132 high school students" were murdered while "in Torun 65 persons from among the local intelligentsia were murdered" 284 . The issue from 1940 returned to the topic of murders in Bydgoszcz, stating briefly in the report from that city that the "tens of thousands of the murdered, tortured and imprisoned inhabitants of Bydgoszcz" still remain uncounted ${ }^{285}$.

In January 1940 the magazine pointed out the variety of the methods of extermination, that the mass executions organized in Pomerania do not constitute the whole problem. It stated that: "The dreadful German terror in the Polish lands annexed into the Reich takes various forms. Apart from numerous executions by firing squad, thousands of Poles are put in prisons and concentration camps where due to tortures, cold and illnesses a large percentage of our compatriots die"286. An issue from August 1940 contained more specific details, e.g. "Here are the names that the society remembers the best, the citizens who died of an illness or were tortured to death or, in other words, were slaughtered in German abattoir: Jonas, Wolniewicz, Witt, Wiencek (his two sons are still in the camp); the landowners Kentzer, Mysłakowski,

${ }^{282}$ Polska Żyje, nr z 15 X 1939, p. 4.

${ }^{283}$ Polska Żyje, nr z 1 XII 1939, p. 2.

${ }^{284}$ Ibid. In fact the repressions affected to some extent the youth from the secondary schools and scouts. It was a retaliation act for the participation of young people in combatting the German subversion on 3 Sept 1939. See: W. Jastrzębski, Terror i zbrodnia. Eksterminacja ludności polskiej i żydowskiej $w$ rejencji bydgoskiej $w$ latach 1939-1945, Warszawa 1974, pp. 28, 30, 34-35, 39.

${ }^{285}$ Z Bydgoszczy, Polska Żyje, nr 43-44, 1940, p. 14.

${ }^{286}$ Hakata szaleje, Polska Żyje, nr z 20 I 1940, p. 1. 
Działowski; school inspector Riess [...] The leading landowners from Pomerania - Czarliński, Donimirski, Ossowski - deported in the autumn, disappeared without a trace"287.

In 1940 Polska $\dot{Z} y j$ informed slightly vaguely about the situation of people in the temporary camps organized by Germans in Pomerania: "A dozen or so thousand people spent the whole winter in unheated dungeons of the Torun forts. Also, Polish people were imprisoned in all the Pomeranian counties. [...] Those who survived were deported in February and March to the Reich. Among them are all teachers, all landowners, a great number of priests, the elderly, the ill, and women" 288 . One of the following issues of the magazine stated that after the prisoners from the Torun forts had been sent to the camps, mortality among them began to increase rapidly: "After two weeks, the first scant pieces of news about the inmates began to trickle. One family was informed by a phonogramme that their breadwinner died in the camp of a kidney illness (and he had never suffered from that!); another woman received a message that her husband, a father of four, hanged himself. The number of such notices was increasing" ${ }^{289}$.

After the capitulation of France in 1940 Polska Żyje presented the following portrait of the moods in Polish society: "Faces show anxiety, in many eyes shine tears of anger and despair... The visions of pessimists have been fulfilled [... It cannot be hidden that France as an ally was a disappointment, that it worsened the situation of our government and army. The days we are experiencing now equal in sadness the darkest times of our history. Yet let us not break down. The fall of France will not influence the ultimate result of the war. [...] Great Britain, the greatest power in the world, will spread all her might. America will provide us allies with increasing support" ${ }^{290}$.

After the members of KOP and ZWZ were arrested in the autumn of 1940 in Warsaw and in Pomerania, and imprisoned in the internment camp in Grudziądz, Polska Żyje published a short note. In December 1940 they wrote: "It ought to be noticed that all the ar-

\footnotetext{
${ }^{287}$ Na Pomorzu, Polska Żyje, nr 65, z 17 VIII 1940, p. 4.

${ }^{288}$ Sytuacja na Pomorzu, Polska Żyje, nr 54, 1940, pp. 4-5.

${ }^{289} \mathrm{Na}$ Pomorzu, Polska Żyje, nr 65, z 17 VIII 1940, p. 4.

${ }^{290}$ Polska Żyje, nr 57 z 22 VI 1940, p. 1.
} 
rested are put by the occupant's authorities in the internment camp in Grudziadz, where prisoners from Warsaw are also taken. Clearly the enemy is creating in Pomerania a second Oświęcim [Auschwitz]"291.

In 1940 reports from Pomerania, Polska Żyje accentuated that that region had quickly changed its appearance: "A few days after the German occupation began, Pomerania has drastically changed its external appearance. Neither in the country nor in the city will you find printed words in Polish. On each house a svastika flag is fluttering, every nook and cranny is full of uniforms and party armbands. Loud conversations in German in the streets and the shouts of the sellers mispronouncing the titles of German newspapers strengthen the impression of "indigenous Germanness " "292. The closing of Polish schools in Pomerania received only a brief statement: "Polish schools obviously have been closed for a long time"293.

Polska Żyje was one of the first underground magazines to relay from Pomerania official statements by the representatives of the German authorities, which contained declarations of intent to make this area fully German. A report from Pomerania from mid-1940 quoted: "»We have to ensure that in five years there will be not a single Pole in Torun!! said one of the greatest Polonophobes, the hate-spreading Pomeranian gauleiter Forster in his speech in the Torun town square" 294 .

Polska Żyje noted that actions focused on immediate Germanization had been quickly implemented in Pomerania. The issue from August 1940 stated: "All Polish inscriptions have disappeared from churches and cemeteries. On the graves, any inscription besides the name and surname must be in German"295. It reported also the removal of the Polish language from religious services.

The problem of rapid Germanization of Pomerania at the beginning of the occupation was covered in Polska Żyje as well. In June

${ }^{291}$ Polska Żyje, nr 85, z 20 XII 1940, p. 6. It refers to Internierungslager der Gestapo in Grudziądz.

${ }^{292}$ Sytuacja na Pomorzu, Polska Żyje, nr 54, 1940, p. 3.

${ }^{293}$ Ibid., p. 5.

${ }^{294}$ Polska Żyje, nr 43-44, 1940, pp. 14-15.

${ }^{295} \mathrm{Na}$ Pomorzu, Polska Żyje, nr 65, z 17 VIII 1940, p. 4. 
1940 the news from Lipno and Rypin counties contained brief information that the use of Polish language was not allowed there in public places, e.g. in shops or in the street ${ }^{296}$. In September 1940 the magazine stated that "Fines and prison sentences for speaking Polish [are] the order of the day" 297 .

The reports from Pomerania published in Polska Żyje in the middle of 1940 informed in brief that the Polish priests who had been allowed by the German authorities to remain "had to announce a decree forbidding sermons and even confessions in Polish" ${ }^{298}$. Removal of the Polish language from religious life was described in more detail in the issue from August 1940299. In September 1940 the news from Pomerania and Greater Poland contained only a very general note that in "a certain gmina in Pomerania" the priest and the organist were arrested for conducting "the preparation of children for the confession and communion" in Polish. It stated that they were kept in prison for fourteen days ${ }^{300}$.

The pages of Polska Żyje also contained news about expulsions of Poles in Pomerania. In 1940 Polska Żyje mentioned that many Polish citizens were exiled from Gdynia and that out of 100 thousand inhabitants only 17 thousand remained in that city ${ }^{301}$. There were also general mentions of expulsions in the Pomeranian villages ${ }^{302}$. The reports from Lipno and Rypin counties stated vaguely: "Also here the Poles were expropriated and ousted." The estimates of the Polish population remaining in these counties were exaggerated, stating that it was a mere $25 \%{ }^{303}$. The expulsion of the Polish population of Pomerania was also mentioned in November 1940 as a still ongoing process ${ }^{304}$.

${ }^{296}$ Z Lipnowskiego i Rypińskiego, Polska Żyje, nr 57, z 22 VI 1940, p. 13.

${ }^{297}$ Z Wielkopolski i Pomorza, Polska Żyje, nr 63, z 14 IX 1940, p. 4.

${ }^{298}$ Sytuacja na Pomorzu, Polska Żyje, nr 54, 1940, p. 5.

${ }^{299} \mathrm{Na}$ Pomorzu, Polska Żyje, nr 65, z 17 VIII 1940, p. 4. See: J. Sziling, Polityka okupanta hitlerowskiego wobec Kościoła katolickiego 1939-1945, tzw. Okregi Rzeszy: Gdańsk-Prusy Zachodnie, Kraj Warty i rejencja katowicka, Poznań 1970, s. 125-126.

${ }^{300}$ Z Wielkopolski i Pomorza, Polska Żyje, nr 69, z 14 IX 1940.

${ }^{301}$ Polska Żyje, nr 33, 1940, s. 6. Takie same liczby podano w organie programowym KG ZWZ "Wiadomości Polskie”. Zob. Konająca Gdynia, Wiadomości Polskie, z 20 IV 1940.

${ }^{302}$ Hakata szaleje, Polska Żyje, z 20 I 1940, p. 1.

${ }^{303}$ Z Lipnowskiego i Rypińskiego, Polska Żyje, nr 57, z 22 VI 1940, p. 13.

${ }^{304}$ Z Pomorza, Polska Żyje,nr 82-83, z 30 XI 1940, p. 6. 
There were also very general reports about some Poles in the Pomerania being issued German idnetity cards. In the mid-1940 Polska Żyje provided a translation of a fragment of a speech given in Bydgoszcz by Werner Kampe, who stated among others that "The cases of the so-called "German identity cards « should be investigated more meticulously [...] The »warranties « that Germans sign for Poles are a betrayal of Germanity and overstep the Führer's order. Who provides a signature to a Pole, provides it to a murderer of a German mother and a German father $[\ldots]]^{3_{305}}$.

Polska Żyje also dealt with the issue of seizing polish property in the Western lands. It was described in January 1940 in the article "Hakata szaleje" ["Hakata on the Rampage"] ${ }^{306}$. One of the following issues stated: "In material aspect, the population is oppressed by the institution of thieves called »trustees « (Treuhänder). [...] Not mentioning factories and large landed properties, even the smallest shops and farms of several acres have their own »trustees". The Poles do not see a penny of the profits from their enterprises; at most they may work there for meagre remuneration as the lowest of workers. Every Treuhänder strives to get rid of the rightful owner who keeps an eye on his dirty fingers" ${ }^{307}$.

Polska Żyje quite early provided information about the moods among the Polish population in Pomerania. It was understandable as KOP quite soon established their intelligence structures in Pomerania, gathering information also with regard to mindsets. The article "Sytuacja na Pomorzu" ["The Situation in Pomerania"] characterized the attitudes of the Poles in that territory at the beginning of the occupation in such words: "Never before has Pomerania seen such unification and consciousness among the masses. The hottest fire tempers the characters. The vicious cruelty of Germans has alienated all the groups and classes. There is no Pole on the Polish lands who does not believe most strongly that they will pay for blood with blood, for casualties with casualties. The hate of the Pomeranian people has reached

\footnotetext{
${ }^{305}$ Z Bydgoszczy, Polska Żyje, nr 43-44, 1940, p. 14.

${ }^{306}$ Polska Żyje, z 20 I 1940, p. 1.

307 Sytuacja na Pomorzu, Polska Żyje, nr 54, 1940, pp. 4-5.
} 
the state of the highest tension. This fact is ascertained without an iota of exaggeration" ${ }^{308}$.

As early as January 1940 Polska Żyje informed about the publication of an illegal proclamation in German. It stated only that it was to appear in Polish territories "incorporated" into the Reich, without specifying whether in Pomerania too ${ }^{309}$.

Only in August 1940 did Polska Żyje inform - without much detail - about the arrests made in the area of Pomerania in the spring of 1940. It wrote e.g. that in the Torun forts "a large group of school students was also imprisoned". The reasons for arrests were covered with vague "several girls, about fifteen years of age, were arrested for reading a newsletter and taken to Germany as forced labourers" ${ }^{310}$.

In Nieszawa and other sub-districts of KOP, the propaganda activities were well developed. A smoothly working network was organized for the distribution of the press (mainly the magazine Polska $\dot{Z} y j e)$ and various leaflets ${ }^{31}$. In Włocławek quite active was Walenty Piętka, codename "Józef". He participated in creating the communication network between Włocławek and Kutno. In 1940 he smuggled through that route to the GG a lieutenant of the reserves of the Polish Army Wacław Wrześniak, who was hiding in Włocławek to avoid arrest. Piętka was also involved in distribution of the KOP magazine Polska Żyje ${ }^{312}$.

${ }^{308}$ Sytuacja na Pomorzu, Polska Żyje, nr 54, 1940, pp. 6.

${ }^{309} \mathrm{Na}$ obszarach Rzeczypospolitej przyłaczonych do Rzeszy, Polska Żyje, z 10 I 1940, p. 3 .

${ }^{310} \mathrm{Na}$ Pomorzu, Polska Żyje, nr 65, z 17 VIII 1940, p. 5.

${ }^{311}$ B. Ziółkowski, Kujawski Związek..., s. 97; FGEZ, Inspektorat Włocławek, teczki osobowe: A. Michalska, H. Szczepańska, T. Zalewski.

312 Ibid. 


\section{Chapter IV}

\section{THE GESTAPO'S ACTION OF ELIMINATION AND INVESTIGATION}

\section{The first arrests}

It is known that the Gestapo made arrests of the KOP members both in Pomerania and in Warsaw. Now it is hard to establish which of the KOP members with Pomeranian connections was the first to be arrested. Due to the lack of documents related to the investigation of KOP in Pomerania, the information regarding this issue can be found only in post-war accounts. Zbigniew Stankiewicz, who organized the KOP structures in Aleksandrów Kujawski and Nieszawa, wrote: "Arrests. Already at the beginning of 1940 we lost the son of military surgeon Duszyński. Careless, he carried a KOP badge in his wallet. He explained that in 1939 a soldier gave it to him as a keepsake, but the Germans did not believe him. [...] He was transported to Germany and executed there. There were a few other arrests for KOP badges and the magazine Polska Żyje [Poland Lives] published by KOP. Luckily those cases were not so exacerbated and ended in the captured people being sent to concentration camps" ${ }^{313}$.

The first KOP-related arrests on a larger scale took place in Torun, where at the beginning of March 1940 the whole Polish underground movement was exposed on a large scale, beginning from the arrests of the members of the local organization "Batalion Śmierci" [full name "Battalions of Death for Freedom"], which had connections to the Po-

${ }^{313}$ FGEZ, rel. Z. Stankiewicza, sygn. M 65/694 Pom., p. 24. 
meranian DistrictDivision of KOP and the Pomeranian structures of [ZWZ] the Union of Armed Struggle as well as to the Pomeranian banner of the Gray Ranks.

As there are no documents from the investigation conducted by the Gestapo of Torun and Grudziądz since the spring of 1940, the course of the action of elimination is known mostly from post-war reports. It was possible to establish that on 6 March 1940 the officers of the Torun Gestapo arrested a fire service lieutenant Alfons Zaborowski, codename "Zgrzyb", who maintained personal contacts with the members of the "Battalions of Death" ${ }^{14}$. During the investigation he broke under torture and revealed what he knew of the names of the members of KOP and other underground organizations then active in Torun, with whom KOP had closer relations. Witold Lendzion thus described the behaviour of Zaborowski after his arrest: "In the mid-March of $1940 \mathrm{Lt}$. Zaborowski was arrested. Basically he told the Gestapo officers everything he knew. He also went with them in a car and, without giving a sign that he had been arrested, he not only pointed out KOP members, but also, through provocative conversations, caused the arrest of their relatives (such as my sister Aleksandra, who spoke a dozen words of truth about Germans). What was important, Zaborowski did not know anybody from the intelligence. I evaded arrest because I was sleeping at the flat of my aunt Kazimiera Jackowska in Łazienna St. Thanks to her, I met with all five people in a row. I told them to continue their work. Kazimiera Jackowska became the liaison. As Piątkowski also was in danger of being arrested, I ordered Honorata to leave Torun and go to Warsaw to the Społem place in Kredytowa St, on the appointed day and hour. Honorata went to Bydgoszcz, where her sister (currently Mrs Thielmann) lived. (...) After making contact with her Bydgoszcz cell of five, she came to Warsaw with the gathered materials. (...) During the last trip K. Jackowska, then the only liaison, came to our flat with the news about new arrests. Following her request, Honorata changed her flat and then, to switch her identity card, she sham-married Jan Stępień

${ }^{314}$ In the postwar accounts there appear various data concerning the date of Zaborowski being arrested. According to some accounts, it took place on 6 March 1950, while according to others in March 1940, or on 16 March 1940. 
and under the name of Maria Stępien she lived till the end of the German occupation. (...) After one more organizational trip to Torun I received an identity card with the name Stanisław Zakonieczny and, on the organization's orders, I went to Zwolen as I was wanted by the Gestapo. The only man who knew my address and name was Pawel Piątkowski, who could not withstand torture and caused my arrest at the beginning of November" ${ }^{315}$.

The action of elimination carried out by the Gestapo officers against Torun underground in March 1940 allowed them to find names and addresses of subsequent KOP members. On 7 March 1940 in the Torun city hall, the Gestapo arrested a KOP member Bernard Domżalski, who worked there; until 6 July 1940 he was imprisoned in Fort VIII in Toruń ${ }^{316}$.

However, it is known that the commandant of the Pomeranian District Division of KOP Paweł Piątkowski himself likely maintained some contacts with the Battalions of Death, and at least several members of this organization knew of his name and involvement in the underground ${ }^{317}$. With the information gathered during the investigation, the Torun Gestapo made new arrests, which included also KOP members. They did not manage to arrest Piątkowski yet, as at that time he was staying in Warsaw. So the repressions were directed at his family. On 18 March 1940 the officers of the Torun Gestapo arrested in Toruń in Poznańska St. his father Antoni Piątkowski, his mother Agnieszka Piątkowska and his two sisters Urszula and Zofia. They remained under preventative arrest until 13 July $1940^{318}$. It is only known that after their release, Paweł Piątkowski "several times contacted his

${ }^{315}$ FGEZ, t. os. Modrzyńska Honorata, List W. Lendziona do E. Zawackiej z 1 VII 1981, sygn. K 542/542 Pom., p. 2.

${ }^{316}$ IPN GK, 927/3123, OKBZH, Protokół przesłuchania świadka B. Domżalskiego, Bydgoszcz 10 I 1974.

${ }^{317}$ From the postwar account provided by Lieutenat Franciszek Zilke from Torun we know that he introduced his former students Alfons Mirecki and Wacław Holz - members of the 'Battalion of Death' to Paweł Piatkowski. See: AMS, Kol. K. C., Notatka z rozmowy z F. Zilkem z 25 III 1963.

318 See: AMS, Kol. K. C., Pismo ekspozytury gestapo w Toruniu dotyczące Piątkowskich. 
sister (then fifteen-year old Zofia) through intermediaries. He himself was hiding at his acquaintances' place" ${ }^{119}$.

Among those the Gestapo managed to arrest in Torun was Aleksa Sobierajska, who was a KOP liaison on the routes Toruń-Kutno and Torun-Warsaw, so she had the knowledge of the contact points both in Kutno and Warsaw, which posed a significant threat, and not only for the Torun KOP. Forewarned about the arrests, Witold Lendzion - the head of intelligence in the Pomeranian District Division of KOP - managed to leave Torun and reach Warsaw. There he informed Piątkowski about the large scale of exposure of Torun underground movements. After Lendzion escaped from Torun, his family members got arrested: his mother Maria Lendzion and sister Aleksandra Lendzion, who was a member of KOP. Aleksandra Lendzion's cell of five dealt - among other things - with distribution of the KOP magazine Polska Żyje. She also performed various tasks related to intelligence and liaison, and her direct supervisor was Marian Tuszewski. ${ }^{320}$ Following Piatkowski's order, Lendzion passed the function of the head of intelligence in the Pomeranian District Division of KOP to Wiesław Stremlau, codename "Brzezina", and many of his contacts in the organization - to Marian Tuszewski ${ }^{321}$.

During the investigation the Gestapo relatively quickly found the traces of KOP activities in Brodnica. On 18 March 1940 Witold Lendzion's brother, Scoutmaster Jerzy Lendzion as well as Marian Sobociński and Konrad Porada were arrested there. A. Kruszczyński was also interrogated by the Gestapo. Thanks to the heroism of Jerzy Lendzion, other KOP members in Brodnica avoided being arrested. Konrad Porada, codename "Kony", described that situation: "In my flat they arrested Scoutmaster Jerzy Lendzion, who had been sought by the Gestapo since morning. After his arrest, my flat was searched and sealed. Together with Lendzion they also took my housekeeper Maria Konkolewska to the SS office. At the same time Marian Sobociński was arrested in his mother's flat in Kamionka St., and in the afternoon I was

${ }^{319}$ AMS, Kol. K. C., J. Iwańska, Życiorys Pawła Piątkowskiego, Szczecin 31 I 1974.

${ }^{320}$ FGEZ, t. os. Lendzion W., List W. Lendziona do E. Zawackiej z 27 V 1981, sygn. M 393/1016 Pom., s. 1.

${ }^{321}$ K. Ciechanowski, Ruch..., p. 92. 
arrested on the $\mathrm{KKO}^{322}$ premises in Brodnica. After being taken to the SS headquarters in Ogrodowa St., I was thrown in the cellar and after some time I realized that Marian Sobociński and Marta Konkolewska were also there; Jerzy Lendzion, however, was being interrogated in the office. Around 7 p.m. Marta Konkolewska was released (she was about 70 years old), while Jerzy Lendzion, Marian Sobociński and me were taken to the local prison, where each of us was put in a separate cell. (...) Thanks to a brief absence of the guard, we managed to communicate with Jerzy Lendzion, who gave us an extensive description of what he confessed about us. In the morning of the same day, first Marian Sobociński and then I were taken for interrogation. Thanks to the details of which Jerzy Lendzion informed us, our testimonies matched the one he gave the previous day. Around noon we both were released. After several months we started underground work within our »cell of five «, but without any outside contacts" ${ }_{323}$.

Jerzy Lendzion was put by the Gestapo first in Fort VII in Torun, and then sent to the investigation prison in Bydgoszcz, where he underwent intense interrogation. Together with Alfons Zaborowski, Lt. Waldemar Geringer and the leaders of the "Battalions of Death" he was moved to the Gestapo investigation prison in Pawiak ${ }^{324}$. It can be concluded that the investigators were particularly interested in underground connections between Torun and Warsaw.

The Gestapo also made arrests in other places, but there are no specific data on that. Some of post-war reports contained very general information on such events. For example, Aurelia Michalska and Kazimierz Widłaszewski are known to have been arrested in April 1940 in Nieszawa and soon murdered.

${ }^{322} \mathrm{KKO}$ - Komunalna Kasa Oszczędnościowa [the Comunity Savings Bank].

${ }^{323}$ FGEZ, t. os. Porada K., Relacja, sygn. M 350/962 Pom., pp. 1-2.

${ }^{324}$ Zob. A. Gąsiorowski, Szare Szeregi na Pomorzu 1939-1945, Toruń 1998, s. 89; W. Jastrzębski, Terror i zbrodnia. Eksterminacja ludności polskiej i żydowskiej $w$ rejencji bydgoskiej w latach 1939-1945, Warszawa 1974, p . 216. In some publications the wrong information appears that Jerzy Lendzion died in the Gestapo prison in Bydgoszcz. Comp. W. Jastrzębski, Terror i zbrodnia..., s. 216; J. Jankowski, Harcerstwo Pomorza Gdańskiego i Kujaw 1911-1945, Toruń 1988, p. 288 (here: “aresztowany w marcu 1940 r., zamordowany w więzieniu w Bydgoszczy" [arrested in March 1940 and murdered in the prison in Bydgoszcz]). 
Essentially, we know little about the investigation conducted then by the Gestapo in Torun. One can only suppose that in its course the Gestapo officers obtained more information regarding the activities of KOP in Pomerania. However, no new arrests were made, so in March and April of 1940 the action of elimination was quite limited with regard to KOP. It probably resulted from a Gestapo tactics involving finding out the details about organizations and learning more about the underground structure through police methods, so as to start another elimination at a suitable moment.

It is difficult to ascertain when the KOP members from other Pomeranian cells were arrested. The post-war report of Hieronim Kmiecik, an inhabitant of Tczew, says that his brothers Witold Kmiecik and Czesław Kmiecik were arrested in the spring of 1940, although the man's memory may have been faulty and the arrests occurred in the autumn of 1940 . Witold was transported from Tczew to Grudziądz and imprisoned. There is no specific information about the course of his investigation; the only detail known is that, among other things, he stood there in waist-high water for three days ${ }^{325}$. In turn, Czesław Kmiecik was probably arrested in Bydgoszcz and handed over to the Gestapo in Grudziądz, from where after the investigation he was sent in March 1941 to Stuthoff camp, where he was given the number $10538^{326}$.

2. The betrayal of the KOP District Headquarters liaison Władysław Jędrzejewski

It must have been at that time - in the spring of 1940 - that the Gestapo achieved their greatest success in uncovering the KOP structures in Pomerania. In unknown circumstances, the Gestapo (probably the Gestapo branch in Rypin) detained Władysław Jędrzejewski, codename "Ostoja" who was a courier of the Pomeranian KOP headquarters. He was the intermediary through whom Marian Tuszewski passed the intelligence data collected in the area of Pomerania by KOP members to Piątkowski in Warsaw. The post-war testimony of Walter

${ }^{325}$ AMS, Rel. H. Kmiecika z 13 IX 1990.

${ }^{326}$ AMS, Podręczna kartoteka więźniów. 
Ziesner a.k.a. Władysław Ciężnikowski, an interpreter at the Gestapo offices in Grudziądz, leads to the conclusion that the cooperation of Jędrzejewski with the Gestapo began in the spring of 1940 - so it started after the first wave of arrests. Ziesner in 1952 327 thus presented the circumstances of Jędrzejewski's cooperation with the Grudziądz Gestapo as their agent: "It was in May or June (I don't remember the exact date) of the year 1940, when the head of the external service of the Grudziądz Gestapo Comissar Franz Schräder called me and announced that I would have to translate for the senior clerk Autenreib during the investigation against a Polish underground organization, because the interpreter who Autenreib brought from Rypin does not know how to translate well from Polish. Then I went to the room where he told me to go; there I found the senior clerk Autenreib, who used to be the Head of the Gestapo in Rypin, with another man. Autenreib was then writing down a report, given by another man who was there with him. As I was interpreting, I found out that the man was, as I have mentioned above, Władysław Jędrzejewski from Czernikowo in the Lipno powiat [county], who was used by the Rypin Gestapo as their snitch in investigating underground organizations. (...) In his testimony, Jędrzejewski provided Autenreib with a number of documents that were proofs against the underground in the Pomeranian voivodeship and in Warsaw, which he received in Warsaw [...] I know there were different original versions of organization letters, decrees, illegal magazines edited in Warsaw" ${ }^{328}$.

It can be deduced from this that Jędrzejewski handed the Gestapo many KOP documents which let the officers discover the current activities of this organization. He also passed information on the KOP members he met both in Pomerania and in Warsaw, as well as the contact locations in Warsaw where he probably had meetings with Piątkowski. This allowed the Grudziądz Gestapo to investigate also KOP in Warsaw. The statement of Ziesner, the interpreter from the Gestapo office in Grudziądz, is the only source from which we know that the officers of that branch were the ones who arrested in War-

${ }^{327}$ Ziesner was imprisoned for the first time in July 1949 - he was interrogated about Wałdysław Jędrzejewski’s cooperation with the Gestapo in Grudziądz.

${ }^{328}$ IPN BY, 044/339, t. 2, Protokół przesłuchania Waltera Ziesnera z 18 VII 1952. 
saw the KOP members with connections to Pomerania. Information from the Gestapo agent Jędrzejewski was particularly helpful in that matter. Ziesner in his testimony described it very tersely: "Based on these proofs and his [Władysław Jędrzejewski’s - A.G.] extensive explanations, the Gestapo both from Rypin and from Grudziądz left for Warsaw, where they arrested many people, who were transported to the Gestapo in Grudziądz; also a few persons from the Pomeranian voivodeships were then arrested, among them the commandant of the underground organization in Pomerania, citizen Wiśniewski. The Gestapo arrested about 20 people, who after the investigation were sent to concentration camps" ${ }^{329}$.

It is difficult to establish now whether the Gestapo officers from Grudziądz and Rypin were assisted in those arrests by the Gestapo officers from Warsaw. It appears so, as the people arrested in Warsaw during that action were not transported immediately to Grudziądz. First they were subjected to interrogation in the Gestapo Warsaw offices in Aleja Szucha. Also one of German documents contains information that the arrests of the KOP members in Warsaw were made by the Grudziądz Gestapo or - on the order of that branch - the Warsaw Gestapo $^{330}$. It is not known, however, which cell of the Warsaw Gestapo participated in this action; the names of the officers from the Warsaw Gestapo who investigated this case are also unknown.

As regards the circumstances of the arrest of Paweł Piątkowski, his sister Jadwiga wrote many years later: "They had been searching for my brother for three quarters of a year [...] Unfortunately I don't have detailed knowledge of the circumstances of his arrest, the time he spent under investigation and his death, as there are different versions providing different details, but I am sure that his demeanour fully deserved to be called heroic" ${ }^{331}$. Piątkowski, who had been living for a long time in the GG [General Government], married in October 1940 his liaison Zofia Turkowska, codename "Zosia" and, warned that the Gestapo were again looking for him, he hid in Celestynów. He also

${ }^{329}$ IPN BY 044/339, t. 2, Protokół przesłuchania Waltera Ziesnera z 18 VII 1952

${ }^{330}$ AMS, sygn. I-III-11029, t. pers. Walentyny Narewskiej.

${ }^{331}$ AMS, Kolekcja K. C., J. Iwańska, Życiorys Pawła Piątkowskiego, Szczecin 31 I 1974. 
lived at that time in Warsaw in Niepodległości St. and in Wiśniowa St. It was in a street in Warsaw that he was arrested on 2 November 1940 by the Grudziądz Gestapo ${ }^{32}$. Judging from this, he must have been followed earlier. He was imprisoned first in Pawiak prison, from where he was driven for brutal interrogations in the building of the Warsaw Gestapo in Aleja Szucha.

As German documents pertaining to the investigation are missing, the only relatively general information about those events can be found in the quite extensive account of Maria Zalewska-Pitera, one of the KOP members arrested in Warsaw at that time ${ }^{333}$. In 1964 she gave a quite detailed description of the circumstances of her arrest and the course of the interrogation: "Thanks to the betrayal of the former courier "Ostoja", who was the courier between Torun and Warsaw, on 2 October 1940 the Gestapo arrested a group of 150 people ${ }^{334}$; among those arrested on that day was Paweł Piątkowski, who died in Stuthoff, Witold Lendzion ${ }^{335}$ and many others. There were eleven women arrested in that group; I don't recall all the names now. I remember Mrs Walentyna Narewska, Mrs Bołtuć, Hania and Iza Malejko, Halina Stencel ${ }^{36}$ from Warsaw, and Barbara Straszewska ${ }^{33}$. We didn't know then who and how many people were arrested in connection with this so-called Torun case. We were delivered to Szucha St. I was arrested in my friend's flat at the corner of Krakowskie Przedmieście and Kozia St. (Kozia 12). (...) They interrogated me for a very long time and in

${ }^{332}$ Some sources say it occured earlier - on 2 Oct 1940.

${ }^{333}$ She wrote very cursorily about her activity in KOP after arriving in Warsaw from Lviv in mid-October 1939: 'After arriving in Warsaw I quickly established contacts through various acquaintances'.

${ }^{334}$ It is hard to check this number. From the work by R. Domańska, Pawiak..., pp. 102-103 it may be inferred that in the first days of October 1940 in Pawiak no more people were placed. At that time every day the germans brought from a few to a dozen of prisoners. It seems unlikely that such a big number of prisoners be placed at 25 Aleja Szucha, where there were four group cells called "tramways" and ten individual cells for prisoners arrested in connection with issues of high importance. See: Obozy hitlerowskie na ziemiach polskich 1939-1945, Warszawa 1979, s. 543-544.

${ }^{335}$ Witold Lendzion in his account says that he was arrested on 3 Nov 1940; probably Zalewska-Pitera after years did not remember the date well; so, Piątkowski was arrested not on 2 Oct, but 2 Nov 1940.

${ }^{336}$ Error. Probably Halina Stanke.

${ }^{337}$ From other sources we know she used the surname Grosik. 
detail, drove me to Szucha, to Pawiak, drove me at night around Warsaw and ordered to show different flats, about which I pretended to have no knowledge, explaining that I don't know any Warsaw flats, that I hardly know Warsaw at all as I had lived in Lwów. I remember some of the interrogations well. I recall for example the one when I saw in the files my letter - a report which I gave to »Ostoja". As the typewriter was then out of order, I was writing by hand, so I recognized my own handwriting immediately and when they showed it to me, I told them that I did write it" ${ }^{338}$.

\section{Arrests of the members of KOP in Warsaw}

When the KOP members connected to Pomerania were being arrested in Warsaw in the autumn of 1940, the officers of the Warsaw Gestapo had already gathered certain knowledge about KOP, as in the summer and early autumn of 1940 the Gestapo arrested in Warsaw numerous members of the main KOP Headquarters. Among them was the head of the KOP Militia Jan Szwejda ${ }^{339}$. It can be concluded that the events which occurred on 14 September 1940 were of utmost importance - although the reports we have are divergent. On that day the Warsaw Gestapo arrested Wincenty Daremniak, codename "Brzoza", the head of the Security Department of the KOP Headquarters ${ }^{340}$. On that day was also captured Jan Bogobowicz, codenames "Janusz Wacławski", "Litwin" and "Kapucyn", who was the head of security of KOP printeries whereas the main commandant of KOP Henryk Borucki, codename "Czarny", and the head of the Propaganda Department of the KOP HQ Lucjan Kołaciński barely avoided arrest. One of the versions describes the following circumstances: the Gestapo barged into the KOP secret premises at 1 Lwowska St. in Warsaw where Jan Bogobowicz was staying, and the officers prepared an ambush. After some time Henryk Borucki and Lucjan Kołaciński came to that place. Borucki was dressed as a woman, which probably resulted in the Gestapo officers letting their guard down. As they were trying

${ }^{338}$ AMS, Relacje, t. XV, Rel. M. Zalewskiej-Pitera z 11 i 12 VI 1964, s. 243-246.

${ }^{339}$ In the document issued by the Gestapo it said he had been arrested in October 1940.

${ }^{340}$ See: IPN BU, 0330/246, t. 5, k. 15. 
to drag Borucki into the flat, he managed to pull out a gun and shoot several times, killing on the spot an officer of the Warsaw Gestapo, criminal assistant Bereuter, and wounding the Gestapo interpreter Otto Schulz ${ }^{341}$. The KOP members managed to leave the apartment immediately. Bogobowicz, wounded in the leg during the shoot-out, was detained in Koszykowa St. by the officers of the Blue Police [Polish Police of the General Government] and put in hospital in Koszykowa St. under guard. There he was arrested by the Gestapo ${ }^{342}$. In retaliation, all the inhabitants of the house at 1 Lwowska St. were arrested as well as all men from the neighbouring house of 3 Lwowska St. ${ }^{343}$

The killing of the Gestapo officer Bereuter had tragic consequences - during the reprisal action ordered on 17 September 1940, in a mass execution in Palmiry 200 prisoners from Pawiak (180 men and 20 women) were executed by firing squad. This group also included the members of KOP and the leaders of the "Battalions of Death" arrested in Torun who had been earlier sent from the Gestapo prison in Bydgoszcz to Pawiak in order to continue interrogation. At that time the following members of the "Battalions of Death" were executed: Wanda Bukiewicz, Edmund Czyżniewski, Lt. Bogdan Gawalski, Wacław Holz, Jadwiga Kowalska and Alfons Mirecki; from KOP in Toruń - Lt. Waldemar Geringer and Franciszek Alfons Zaborowski; from KOP in Brodnica - Jerzy Lendzion ${ }^{344}$.

Also in September 1940 was arrested the inspector of military groups in the KOP HQ major Marceli Cerklewicz, codename "Paszota", who before coming to Warsaw did underground work in Torun as the head of the "Grunwald" organization. In September 1940 were arrested Zbigniew Gorczyński, codenames "Rawicz" and "Oporski”, the deputy head of the Security Department of KOP HQ, and Stanisław Lewandowski, codename "Krawczyk", who took over as the head of

${ }^{341}$ Another version of this event is provided by W. Bartoszewski, Warszawski pierścień śmierci 1939-1945, Warszawa 1970, p. 101.

${ }^{342}$ M. Wiśniewski, Z historii powstania i działalności Komendy Obrońców Polski, Wojskowy Przegląd Historyczny, 1967, nr 3, s. 243; IPN BU, 0330/246, t. 4.

${ }^{343}$ We can only indicate a slightly different description of the dramatic events at 1 Lwowska Street, which appears in the investigation files of Henryk Borucki. See: IPN BU, 0330/246, t. 7, k. 7.

${ }^{344}$ R. Domańska, op.cit., pp. 92-94. See also: W. Bartoszewski, op.cit., pp. 97-100. 
the Security Department of KOP HQ after the arrest of Daremniak. On 30 September 1940 the officers of the Warsaw Gestapo arrested Witold Hulewicz, the editor of the KOP magazine Polska Żyje ${ }^{345}$. A great success of the Gestapo was arresting in September 1940 Stefan Helmuth, codename "Stefan", an interpreter of the Warsaw Gestapo who cooperated with the $\mathrm{KOP}^{346}$.

During the quite vigorously conducted investigation, the Gestapo obtained information on the functioning of many KOP structures working in Warsaw as well as outside the city, including the local units of this organization in Cracow, Silesia and Pomerania. This let the Gestapo undertake a widespread police action against KOP. Therefore the arrest of Piątkowski should be treated as the beginning of a planned Gestapo action of eliminating the Pomeranian structures of KOP.

A person of particular interest during the investigation was Paweł Piątkowski, not only because he was the commandant of the Pomeranian District Division of KOP. If the information related after the war by Henryk Borucki, codename "Czarny", the head commandant of KOP, Piątkowski was also the head of intelligence for the [Third] Reich area, and this was what particularly interested Gestapo officers. As Borucki was arrested for the first time in January 1941 - at the time when Piatkowski was under further investigation at the Gestapo in Grudziądz - he was probably sent back to Warsaw and put in the investigation prison of the Gestapo in Aleja Szucha. Here he was confronted among others with Henryk Borucki a.k.a. "Czarny" and Dr Leon Wasilewski, a member of the command of the Western Inspectorate of KOP, who before leaving Pomerania for Warsaw was one of the leaders of the "Grunwald" organization ${ }^{347}$.

${ }^{345}$ After the investigation had finished, he was executed on 12 June 1941 in Palmiry during the mass execution during which 15 men and 14 women were shot dead. Other people killed there included: Jan Sochacz, the head of the militant group of KOP; three young girl scouts: Krystyna Mincberg, Jadwiga Przybylska and Anna Skuratowicz. W. Bartoszewski, op.cit., p. 110.

${ }^{346}$ In the Gestapo documents it read that he had been born in a village located in Pomerania (Westpreussen).

${ }^{347}$ K. Ciechanowski, op.cit., p. $80 \mathrm{i}$ in. 
After the war Borucki described not only the reasons for arrests and their scale but also the pieces of information on the course of the investigation passed by the arrested KOP members imprisoned in Pawiak: "Well functioning sections in prison are also cooperating with the organization's counterintelligence with increasing fruitfulness. As we receive from the prisoners reports on investigations, descriptions of their arrest etc., we frequently manage to unmask Gestapo agents and collaborators. In this way we managed among others to uncover an extremely dangerous Gestapo agent, one Władysław Jędrzejewski, codename "Ostoja", who caused the capture of a large section of KOP working in Pomerania (e.g. the arrests of Maria Bołtuć, Paweł Piątkowski, Karol Starzewski and many others). In the light of the reports - smuggled out of prison - from multiple people arrested in connection with this case, the character of "Ostoja" looked increasingly suspicious. However, the full unmasking of this agent happened due to the reports from the prisoner Maria Pitera. This colleague, who did not belong to the main group accused in the so-called "Pomeranian case" and therefore was not the first to be asked for a report by the prison section, turned out, however, to have the most to say about "Ostoja « - and these, coincidentally, were essential things. Here is a fragment of Maria Pitera's account: "I made an appointment with »Ostoja (I'm not sure if Władysław Jędrzejewski is his real name, so I’m going to use his codename) on 2 November 1940 at 6:30 p.m. in the flat at 12 Kozia St. in Warsaw. "Ostoja « was at that time the liaison with Torun. On that day he phoned me that he had first-class material. A dozen or so Gestapo officers in uniforms spread around the whole flat and started a search. They told me to get dressed and get ready to leave. I was dressing at the end of the hallway where the light was dim, and »Ostoja«, who had just entered, did not notice my presence. On seeing him I was petrified that he fell into the trap with this "first-class material «, but then I heard him ask the Nazi what time they had come here (Maria Pitera knew German HB). The officer answered that at 7:10 p.m. Then »Ostoja" started lashing out that they had come too late, that if they had come at half past six, they would have gotten «all the birds" in hand." The account of Maria Pitera was immediately passed to Paweł Piątkowski, Karol Starzewski and may other prisoners arrested in connection with 
this case; it was also sent to the relevant sections of the organization remaining "at large«. An investigation and observations carried out by counterintelligence confirmed that »Ostoja « was guilty. The organization pronounced a death sentence on him. The fact that the numerous group of prisoners from the »Pomeranian case« were able to immediately communicate among themselves and quickly smuggle out of prison some letters with reports and warnings, that the calamity had not reached a disastrous scale, and that a part of those prisoners, even in camps, did live to see the end of the war - must be largely credited to the prison section of KOP and one of its most devoted officers at that time - the prison guard Stanisław Lewandowski" ${ }^{348}$.

4. The investigation by the Gestapo in Warsaw and Grudziądz and further arrests

After the investigation in Warsaw, the KOP members with connections to Pomerania who had been arrested there were put at the disposal of the Gestapo office in Grudziądz. Now it is difficult to establish which prisoners leaving the investigation prison in Pawiak were connected with KOP, and which had been arrested due to their activity within the Pomeranian District Division of the Union of Armed Struggle or worked in the sphere where both these organizations overlapped.

The Gestapo office in Grudziądz (Stapostelle Graudenz) had its premises at 7 Młyńska St. (then Königstrasse). Between 1939 and 1943 it supervised the branch offices in Kwidzyn and Rypin. In the years 1939-1940 the head of the Gestapo office in Grudziądz was Fressing, and in 1941 Dr Günther Venediger, who already in the same year was moved to the post of the head of the main Gestapo office in Gdańsk (Leitstapostelle Danzig), which clearly was a promotion. Within the structure of the Grudziądz Gestapo, the most important was Department IV, divided into several sections. Until 1943 the head of the section dealing with eradication of the underground was Kwidzyń-born

${ }^{348}$ IPN BU, 0397/60, t. 2 (bez nazwy wypisy z mat. H. Boruckiego, spisanych przez niego), k. 80 . 
criminal comissar Wilhelm Rettinger ("Ratkowski"), who already before the war was very well oriented in Polish matters.

The data on the investigation conducted in Grudziądz are incomplete. The only known detail is that after her second arrest, the Gestapo officers allowed Agnieszka Piątkowska, the mother of Paweł Piątkowski, to see her son. She was ordered to influence him so that he would reveal all the organizational secrets. The officers were maintaining that they already knew everything and only wanted to confirm their data ${ }^{349}$.

Gestapo operations in the Grudziądz prison - at the time when KOP members were inmates there - were mentioned after the war by Ziesner, an interpreter employed at the Grudziądz Gestapo. "In 1940 or 1941 (I don't remember exactly) there was in the local camp of the Grudziądz Gestapo a man [imprisoned] for participating in the »Polish underground movement . The aforementioned individual reported the news from the camp to inspector Rettinger. I translated several of his denunciations into German as he did not know this language. Those denunciations regarded his fellow inmates and pointed out the conversations carried out in the camp and the political attitude of certain prisoners. They also contained accusations that some prisoners listened to the radio (at the camp was a workshop where a radio technician mended radio sets for Gestapo employees) and that they tuned in to foreign stations and then spread in the camp what they had heard. That man was released, got a job in Lipno (at a transport business and as an informer he maintained contact with Rettinger). Then he disappeared somewhere and the Gestapo were looking for him as a fugitive. I can't recall his name, but I can give certain clues that should help clear the matter: that man had a brother in law who owned a meat warehouse and a workshop in a place called Osówka in Lipnocounty. The wife of this butcher was actually a sister of our individual. During the occupation that warehouse owner became a Volksdeutsch. Rettinger then ordered them to immediately report if the wanted man should appear at their home" ${ }^{\prime 350}$.

${ }^{349}$ AMS, Kol. K. C., List Jadwigi Pohl (siostry P. Piątkowskiego) z 9 III 1966.

${ }^{350}$ IPN BY, sygn. 0/44/339, 3 pdf, Wyciąg z notatki Ziesnera, Bydgoszcz 1 VI 1953, k. 287; IPN BY, sygn. 0/44/339, 3 pdf, Pismo Kierownika PUdsBP w Lipnie z 14 X 1955, k. 
On 2 November 1940, as far as in Zwoleń in Kielce voivodeship, the Gestapo officers arrested Witold Lendzion, the first head of intelligence in the Pomeranian District Division of KOP, who had been wanted by the Gestapo since March 1940 when he managed to escape from Torun before his arrest. He was transported to Warsaw to the Pawiak prison, where Paweł Piątkowski was still an inmate. Although they were kept apart as they were arrested in connection with one case, they managed to exchange several sentences ${ }^{351}$.

Certain pieces of information concerning the scope of arrests made by the Gestapo in Warsaw in connection with the so-called Pomeranian case were presented by the then main commandant of KOP Henryk Borucki. "I met in Pawiak the traces of the Pomeranian "exposure « There was a prisoner Barbara Grosikówna, arrested on 2 October 1940 in Warsaw at 52 Narbutta St. in one of the contact points of KOP. (...) The Gestapo had not identified her, and her colleagues from the organization had not denounced her during investigation ${ }^{352}$. She was saved from being transported to Grudziądz for a »trial« by a severe illness" ${ }_{353}$.

According to Borucki, in Warsaw Paweł Piątkowski also was in direct contact with KOP cells dealing with social actions. He mentioned it in these words: "I would have never thought before that the Pomeranian »exposure " of Piątkowski's secret cells could be a direct cause of arrests in the section of Father Merklejn. In connection with the Pomeranian »exposure " the following people were arrested in Warsaw: Mrs Bołtuć, the widow of general Bołtuć, the commander of Toruń Infantry Division; Halina Stanka (now Glinkowska) and her brother; Jan Wasicki, Maria Pitera, Iza Malejkówna, Adam Roguski, Karol Staszewski and Brzozowski" ${ }^{354}$.

As the transport list and Grudziądz Gestapo documentation from the turn of the years 1940/1941 are missing, it is difficult to complete

305.

${ }^{351}$ AMS, Kol. K. C., Relacja W. Lendziona z 16 XI 1965.

${ }^{352}$ See also: A. Czuperska-Śliwicka, Cztery lata ostrego dyżuru. Wspomnienia z Pawiaka 1940-1944, Warszawa 1965, p. 322.

${ }^{353}$ IPN BU, 0397/60, t. 2 (bez nazwy wypisy z mat. H. Boruckiego, spisanych przez niego), k. 6.

${ }^{354}$ Ibid. 
the list of people arrested in Warsaw in the autumn of 1940 and then handed over to the Grudziądz Gestapo for further investigation of their organizational connections in Pomerania.

On 3 November 1941 in Toruń, Gestapo officers arrested several important KOP members. The people detained then included Adam Przybyła, Zofia Jackowiak, Kazimiera Jackowska, Edmund Lewandowski, J. Starzyński, Witold Stremlau and Marian Tuszewski. Zofia Jackowiak was arrested in her parents' flat in Torun at 7 Kołłątaja St. Two weeks later the Gestapo also arrested her father Marcin Jackowiak, who was also a KOP member, of which his daughter learned only after his arrest ${ }^{355}$.

The Gestapo also made arrests of KOP members in other Pomeranian towns. Due to the lack of documents from the investigation, it was impossible to establish the order and dates of all these arrests. It is only known that the arrests at that time (probably in November of 1940) included: in Brodnica - Father Sylwester Niewiadomy; in Grudziądz - Paweł Rybicki and Zofia Piasecka; in Tczew - a teacher and scout instructor Witold Kmiecik. Maria Socha was arrested in Tczew as her husband Alojzy Socha had managed to hide ${ }^{356}$. It is also known that the Gestapo made arrests of KOP members in Chełmno, Lipno and Rypin, although there has been no specific data published so far ${ }^{357}$.

On 4 November 1940 in Kończewice in Toruń powiat [county] three officers of the Grudziądz Gestapo arrested Stanisław Obiegałka, involved in KOP intelligence activities; he was put in a car where already sat an unknown arrested woman from Bydgoszcz. They were both taken to the Gestapo prison in Grudziądz in Młyńska St. Under investigation in Grudziądz, Obiegałka managed to make an illegal contact with his family. In several smuggled letters he described the conditions in that prison. Nowadays they constitute a chronicle of investigation methods and the ways the guards treated the inmates. Only in his letter from 28 may 1941 he described the moment he was

\footnotetext{
${ }^{355}$ FGEZ, t. os. Jackowiak Z., Relacja, sygn. K 1567/157 Pom., pp. 3-4.

${ }^{356}$ His future fate remains unknown.

357 See: J. Grabowska, Więźniowie, [w:] Stutthof. Hitlerowski obóz koncentracyjny, Warszawa 1988, p. 120.
} 
put in prison: "That day we stood in the rain until the evening in the courtyard, guided by machine g[uns], and in the evening they took us to Amtstrasse where we crossed the so-called dry forest and we spent the first night in the cellar in our clothes on straw. On the following day I was confronted with Stremlau [...] On the third day more interrogation - and it was over for me; the others were taken one by one. In the first weeks we thought only that our days were numbered, but the our hopes have gradually started flaming higher and higher. It used to bother me a lot and still sometimes does, but I am hardened now so various surprises are easier to bear. The Christmas was sad and heavy to bear. On Christmas Eve a transport with our people (with lesser charges) left for the camp (...) Shortly after Christmas the first victim fell: the late Kaczgórski died at 64 from a heart stroke during exercises; his wife was sent to Siberia by Bolsheviks. A reserve officer, an official of Duke Radziwiłł. And so these exercises sometimes took their toll and destroyed health" ${ }^{358}$.

On 8 November 1940 a KOP officer, a Polish Army lieutenant Władysław Jaworowski was arrested in Kutno and then transported to the prison in Grudziądz. During the night of 14 November 1940 Urszula Jedwabna was arrested in Brodnica at 9 Łazienna St. Other people arrested with her in Brodnica were Irena Joachimczyk, Magda Krawcowicz (after the war- Piskorska), Marian Piskorski, Kazimierz Dębski and Jan Sucheński ${ }^{35}$. In his post-war account Urszula Jedwabna told that "Arrests in that case also included the Tuszewski brothers (merchants from Toruń); Adam Przybyła (the editor of Stowo Pomorskie from Toruń); an elderly (93-year-old) woman selling devotional items in front of St James' Church in Toruń; Władka Rygielska from Toruń; Officer Kamiński from Toruń; Franek Włodarczyk (later prisoner functionary / kapo in Stuthoff); Kazimiera Jackowska (later also a functionary); Zosia Jackowiak from Torun (she saved herself after the camp evacuation from the Szwedzi barge); »Hanica « - Maria Zaleska-Pitera; Maria Socha; Maria(?) Jankowska; Grandma Czajkowska from Czernikowo near Rypin; the general's widow Maria Bołtuć who

${ }^{358}$ AMS, sygn. Z-II-4-2, Odpis grypsu S. Obiegałki z 28 V 1941.

359 Jan Sucheński was released, because he was an American citizen. 
lived (then) at 12 Koszykowa St. in Warsaw; Ela Stremlau from Torun; Walentyna Narewska (a Czech) from Warsaw. (The headquarters were located in Warsaw at 99 Podchorążych St.)" ${ }^{360}$.

On 18 November 1940 in Chojnice the Grudziądz Gestapo arrested a member of the local KOP branch Maksymilian Rokita. After the investigation he was imprisoned in Stuthoff camp. In his personal file from the camp there are only documents regarding the order of RSHA in Berlin to continue the preventative arrest of Rokita. The commantant's office of the concentration camp in Stuthoff was informed by the Grudziądz Gestapo office on 15 December 1942 that Rokita received Lagerstufe III [grade III, the toughest] designation and therefore should be sent with the next transport to the Mauthausen camp where people with Lagerstufe III were directed ${ }^{361}$.

In some post-war accounts information can be found that during the elimination of secret cells of KOP in Pomerania the Gestapo arrested circa $250-300$ people, and that about 150 people from that group were released after three or four months of investigation - those who had been arrested by accident as they were not KOP members, or they were detained as relatives of KOP members. For example on 3 November 1940 the members of Paweł Piątkowski's family were arrested again. They were put in the Grudziądz prison probably in order to influence his attitude during the investigation. In Tczew the mother of Witold Kmiecik was also arrested, yet she was released after several hours ${ }^{362}$.

As mentioned before, probably at the end of October 1940 in Warsaw was arrested Maria Bołtuć, the general's widow who had connections with KOP. She was subjected to interrogations in the office of the Warsaw Gestapo in Aleja Szucha, from where she was driven to the investigation prison in Pawiak ${ }^{363}$.

${ }^{360}$ FGEZ, t. os. Jedwabna U., Relacja z 1 XII 1989, sygn. 602-602/Pom. s. 2-3. Jedwabna mentioned the members of KOP and ZWZ.

${ }^{361}$ AMS, KLS, t. pers. M. Rokity, sygn. I-III-13014, k. 3-4.

${ }^{362}$ AMS, Rel. Hieronima Kmiecika.

${ }^{363}$ Such information appeares in the biogram of M. Bołtuć included in SBKP, cz. 3, Toruń 1997, p. 37. 
The artist Aniela Kuśmierek was also arrested in Warsaw. Her flat was a contact point, used among others by the commandant of the Pomeranian District Division of KOP, Sub-Lt. Paweł Piątkowski. Kuśmierek was imprisoned in Pawiak. A member of ZWZ [Union of Armed Struggle] Anna Czuperska-Śliwicka, who was arrested in November 1940 in Warsaw and also had Pomeranian connections because her flat was a contact point for liaisons from that region, described Kuśmierek in her memoirs in this way: "Aniela Kuśmierek, arrested in 1941, a painter with charming appearance. Despite harassing interrogations at the gestapo, which caused in her nervous exhaustion, she knew how to behave beautifully. (...) On 30 May 1942 she was taken with a group of about 250 women prisoners to Ravensbrück" ${ }^{364}$.

We have little information regarding the course of investigation carried out by the Grudziądz Gestapo. It is known that Halina Stenke, imprisoned on 10 March 1941 in Stuthoff camp as the political prisoner No. 10522 was on 20 November 1941 handed over to the Grudziądz Gestapo to be held at their disposal ${ }^{365}$. The available accounts do not contain information why she was reincluded in the investigation. One may only speculate that it was to confront her with Piątkowski, who was at that time being further investigated in this Gestapo branch.

5. Accounts of the investigation process in Grudziądz [Graudenz]

There remain some accounts of what the prison conditions were in the internment camp under the command of the Gestapo in Grudziądz and where the arrested KOP members were kept. First reports were delivered by the KOR member Paweł Rybicki, who, after having been interned there, was transported, together with other internees, to Stutthof (then operating as an internment camp) to be finally transferred to Grenzkommissariat Gotenhafen in Gdynia [Gdingen] located at 8-10 Korzeniowskiego St [Prinz Eugenstrasse] in Kamienna Góra [Steinberg] $]^{366}$, where he was a prisoner working as a gardener doing all kinds of odd jobs not only in the garden surrounding the Gestapo building but also all around the city. Therefore, Rybicki enjoyed some

${ }^{364}$ A. Czuperska-Śliwicka, op.cit.,s. 334.

${ }^{365}$ AMS, KLS, t. pers. H. Stanke, sygn. I-III-15011, k. 2.

${ }^{366}$ Encyklopedia Gdyni, Gdynia 2006, p. 584. 
freedom of movement which he used to plan an escape to Sweden together with Stanisław Babinicz, also a Gdynia Gestapo prisoner working as a mechanic. On 4 May 1943 Rybicki and Babinicz, joined by two brothers, Leon and Dominik Łaniecki, were put on board of the Swedish ship SS Ingeren. They were aided in their escape by members of an AK smuggling unit from Gdynia: Jan Śledź, Franciszek Szwarc, Franciszek Trepczyński, Olszewski and Klara Baszanowska, who secured the escaped prisoners a safe passage to the port and getting on board of the ship. The escape would not have been possible without the help of the Swedish sailors Björn Erlandsson, Pelle (Perle) and L. Skarsvag ${ }^{367}$.

After a brief sojourn in Sweden Paweł Rybicki was smuggled to the UK.

On 31 March 1944 he presented at the Polish Office for War Crimes in London a striking testimony about the internment camp run under the command of the Gestapo in Grudziądz, Stutthof internment camp and the Gestapo seat in Gdynia. Rybicki also reported on his activities within the KOP structure but giving a general picture only.

Forewarned about the legal consequences of giving false testimony, Rybicki declared: "Before the Polish-German war, I worked for the Tax Office in Grudziądz. [...] On 4 November 1940 I was arrested under suspicion of belonging to an underground organization $^{368}$ together with a whole bunch of other Poles. Rumour has it the arrests happened following denunciation by Jędrzejewski, a sergeant of the State Police in Czernikowo, who had allegedly received from the Germans MK 5000 and was given a job in the Gestapo. Among others who were arrested were: Wiesław Stremlau from Toruń [Thorn], Tuszewski and Przybyła from Toruń, Obiegałka from Chełmża [Kulmse] as well as Kmiecik and Socha from Tczew [Dirshau]. They arrested about 150 persons from various Po-

${ }^{367}$ See more: B. Chrzanowski, Organizacja sieci przerzutów droga morską z Polski do Szwecji w latach okupacji hitlerowskiej (1939-1945), Stutthof. Zeszyty Muzeum, nr 5, 1984, pp. 35-36.

${ }^{368}$ Rybicki did not mention the name of KOP in his testimony. It was Ciechanowski who said that Rybicki had been a member of the secret organization of KOP in Grudziądz. Op.cit., pp. 89-90. 
meranian towns and cities as well as Kaczyński (an elderly man from Warsaw). I was detained in the Caritas camp (run by Rev. Budkiewicz) and twice escorted to the Gestapo for questioning. While in the Caritas camp, I experienced repeated injustices committed by the SSScharführer Schönfeld and the SS guard Menke. (...) I remained in the camp until 9 March 1941. During my confinement there I was taken to the Gestapo office, where, using physical abuse Steinkraus he tried to force me to admit that I belonged to the underground movement. (...) Because I denied the allegations, I was sent to Stutthof, together with a large group of about 100. It took us a few hours in trucks to cover the whole distance via Kwidzyn [Marienwerder] and Malbork [Marienburg]. The moment we crossed the camp gate harassment started. [...] Each of us received a number on cardboard (I had number 10553), and from that time everyone was known only by the number you had to put up over your bed. Then they escorted us to the barracks. [...] I was a Stutthof prisoner between 9 March and 22 May $1941^{369}$.

In 1947 in Bad Salzuflen in Germany an officer of the Polish Military Mission for the Investigation of German War Crimes took testimony from Jerzy Moraczewski, who during the Nazi occupation of Poland was a deputy inspector in Inspektorat Ziem Zachodnich KOP (KOP Inspectorate of Poland's Regained Lands). He described at some length the conditions he endured in the so-called internment camp running under the command of the Gestapo in Grudziądz and also the selfless assistance offered to the prisoners by Ziesner aka Ciężnikowski, a translator working for the Gestapo in Grudziądz. According to his testimony, apart from him, other members of underground resistance (KOP and ZWZ/Union of Armed Struggle) arrested in Warsaw were kept there, including a merchant from Torun arrested in Warsaw: Wincenty Siejkowski.

\section{Arrests in Włocławek [Leslau]}

The organizational development of KOP in Włocławek and the district of Włocławek was halted by the measures taken by the Gestapo. The first arrests were made in the autumn of 1940 and continued with

${ }^{369}$ AMS, Zeznania P. Rybickiego, Londyn 31 III 1944 (odpis), pp. 1-11. 
varying intensity until the end of 1941. B. Ziółkowski, a researcher studying the underground activity carried out in 1939-45 in Kujawy (Kuyavia) states that, at the turn of 1940 and 1941, 40 people got arrested, whereas, according to him, "in December 1940 the entire structure of the underground movement collapsed as a result of the arrests. He found out that in 1941 the Gestapo arrested "further 160 people, mostly from among postal servicemen, railway workers, former civil servants and military personnel" ${ }^{370}$. The investigation conducted by the Gestapo revealed links between KOP, KPZL and KSSL. As a result, the Gestapo conducted parallel investigations aiming to decimate and finally take down these three clandestine structures operating in Włocławek [Leslau] and the surrounding area. In the absence of sufficient sources, researchers have been unable to determine how much the investigation into the organizational structure of KOP Włocławek District Division helped the Gestapo obtain additional information about the functioning of KZPL and KSSL on the one hand, and how much dismantling the structures of KZPL and KSSL helped them get new information on KOP, on the other hand. Among those detained at the turn of 1940 and 1941was Jadwiga Czarnecka, suspected of distributing a clandestine KOP publication Polska Żyjel (Poland Lives). It is a known fact that she was collaborating with Wanda Krauze distributing the underground magazine Ogniwo (Link). Because the Gestapo did not have any evidence against Krauze, she was released after 53 days of detention. While assessing the Gestapo's successes in their fight against Polish underground organisations, B. Ziółkowski states: "One can hypothesize that during the detention of KOP members substantial material incriminating KZPL and KSSL conspirators was gathered. The Gestapo managed to get some basic information (evidence) on KZPL and people involved in publishing which they found sufficient to break up the organization. The initial arrests of members KZPL and KSSL collaborating with KOP make the above hypothesis even more likely"371.

${ }^{370}$ B. Ziółkowski, Kujawski Związek Polityczno-Literacki i Kujawskie Stowarzyszenie Społeczno-Literackie na Kujawach Wschodnich w latach okupacji niemieckiej 1939-1945 (Działalność i losy konspiratorów), Toruń 2006, p. 100.

${ }^{371}$ Ibid., p. 173. 
It is believed that the wave of arrests made in Włocławek in 1941, which ultimately led to a total breakdown of such local underground organizations operating there as Kujawski Zwiazek Polityczno-Literacki (KZPL/ Kuyavian Literary-Political Association) and Kujawskie Stowarzyszenie Społeczno-Literackie (KSSL/ Kuyavian Literary-Political Association) were probably a result of extended invigilation of the KOP members who were simultaneously engaged in KZPL activity. Those members were: Franciszek Dankowski, Józef Bieńkowski and Stanisław Mazurek alias Junosza, who from September 1940 conducted a wide range of activities within the KZPL and was also a member of another local organization called Bojowa Organizacja Ludowa (People's Combat Organization). According to some post-war findings, the wave of arrests made by the Gestapo in Włocławek at the beginning of 1941 began with arrests carried out between $24^{\text {th }}$ and $25^{\text {th }}$ January 1941, when the Gestapo arrested Eugeniusz Stein then collaborating with KOP (Stein had been introduced to KPZL by the KOP members F. Dankowski and S. Mazurek in September 1940) as well as F. Dankowski and Józef Bieńkowski, KOP members still in contact with him. On 1 February 1940 the Gestapo arrested in Włocławek the KOP member Stanisław Mazurek alias Junosza as well as the leader of KZPL Eugeniusz Kłosowski and two other KOP members: W. Magielski and J. Dulski, followed by other KZPL members: Janina Lech, Benedykt Lech and Henryk Wojdyłło on 2 February 1940, and Wanda Daszkowska, Leon Sporny aa well as Danuta Turczynowicz on the following day. The total number of people arrested by the end of February 1940 was around 140. The arrests included KOP members also belonging to KZPL as well as members of the latter organization exclusively. Today it is difficult to determine the names of all the KOP members arrested during the Gestapo operation aimed to dismantle Polish underground organisations operating in Włocławek. It is known that among those arrested was Michal Kowalski (b. 1888) from Włocławek, who was a member of both KOP and KZPL. He was arrested on 19 March 1941 and imprisoned in Zwickau following interrogation, where he died on 14 October $1941^{372}$.

${ }^{372}$ Ibid., pp. 183, 203. 
Ferociously hunted down by the Gestapo, a member of both of KOP and KZPL Włocławek, Józef Bieńkowski alias Ostoja (Refuge) was the only one of those arrested already at the beginning of February 1941 who managed to escape from the Gestapo building in Włocławek. After his successful escape, Bieńkowski was highly admired among Poles. Therefore, for the Gestapo his arrest became a matter of prestige.

Despite the precautions taken, Bieńkowski was arrested in Wólka Felińska in April 1941 by a Gestapo officer from Włocławek, J. Frank, who had befriended him before the war and joined the same organization called Strzelec (Rifleman). On 11 April 1941 the Gestapo also arrested Bieńkowski's wife and the Raczek married couple, with whom he had exchanged letters. Bieńkowski's arrest was an unquestionable success for the Gestapo. Józef Bieńkowski was sentenced to death in Włocławek on 12 August 1941 and executed there before 27 April $1941^{373}$.

Fearing imminent arrest, some KOP members decided to escape from Włocławek to the General Government. Among them were: WłodzimierzLaszenkoalias 'Jaskółka' (Swallow), 'Włodek' and Roman Zawicki. After those arrests, KOP was no longer capable of rebuilding its organisation either in Włocławek itself or in its surroundings. All the surviving KOP cells and its individual members later joined other organisations, mainly the ZWZ (Union of Armed Struggle) -AK (Home Army), Polska Armia Powstania (Polish Underground Army) and Ruch Miecz i Pług (Sword and Plow Movement).

In 1941 the Gestapo in Włocławek failed to arrest the KOP member Walenty Piętka alias 'Józef', who maintained contacts with KZPL conducting its clandestine operations in Włocławek but also severely affected by the recent arrests. After losing touch with KOP, Piętka continued to run his underground activities and was invited to join the AK (Home Army) by, most probably, Józef Zieliński alias 'Grab' (Hornbeam), commander of the AK District Włocławek.

In Aleksandrów Kujawski the married couple Bolesława and Tadeusz Zalewski also avoided arrest. They both later joined ZWZ. Ac-

${ }^{373}$ Ibid., p. 239. 
cording to his later testimony, Zalewski was sworn into ZWZ (Union of Armed Struggle) as early as the end of 1940 by Józef Olszewski. His wife alias 'Tążyna' was his courier in 1940-42, maintaining contacts with Bolesław Jarosiński (Captain of the Polish Army Reserve) from Nieszawa [Nessau] and the physician Adam Marlicz in Aleksandrów Kujawski among others. She was also involved in ZWZ-AK intelligence and counterintelligence ${ }^{374}$.

${ }^{374}$ Idem, Kujawski Związek..., 125.

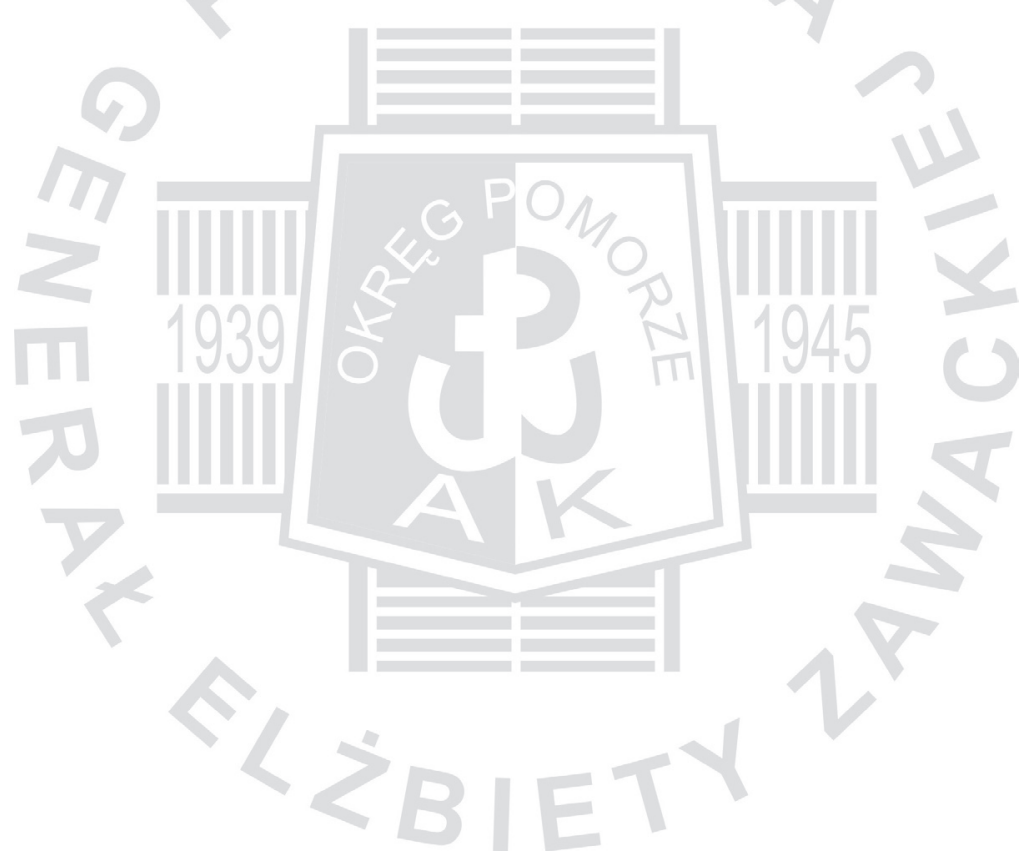




\section{CONCLUSION}

Having established its field structure across Pomerania as early as October 1939, Komenda Obrońców Polski (KOP - Headquarters of the Defenders of Poland) probably was the first nationwide underground organization operating in war-torn Poland. The main initiators of KOP activity in Pomerania were: Tadeusz Odrowski, a well-reputed activist and organizer canvassing for pro-Poland votes during the East Prussian plebiscite, commander of Organizacja Wojskowa Pomorza (Military Organisation of Pomerania) involved in sabotage, intelligence and other forms of struggle for independence, later a social and political activist and associate of $2^{\text {nd }}$ Division of the General Staff of the Polish Armed Forces; and Air Force 2d Lt. Paweł Piątkowski, a young person, not much known in pre-war Pomerania. It did not take long for the founders to establish not only the KOP Pomeranian District Command but its organizational cells in Torun as well, soon followed by KOP cells in other major towns and cities in Pomerania. At the very beginning of the Nazi occupation of Poland KOP gave hope for successful struggle for independence through its widely distributed Polska Żyje (Poland Lives), the most popular clandestine newspaper published at the turn of 1939 and 1940. The paper provided the reader with current news but, first and foremost, it served as evidence of strong links od Pomerania with Warsaw and other parts of Poland right after Pomerania had been incorporated to the Reich, which resulted in the sense of isolation in the people of Pomerania. Incidentally, KOP in Torun had already developed strong interrelationships with other national underground organisations such as SZP-ZWZ and some local ones: Grunwald, with its extensive network of fighters involved in sabotage missions, and Batalion Śmierci (Batallion of Death). While there was some tension between the General Command of KOP and that of ZWZ resulting in a failure to merge those two organizations (KOP and ZWZ) into one in Warsaw, in the case of Pomerania, co- 
operation between KOP and ZWZ ran smoothly from the very beginning, maybe because Grunwald served as a base for ZWZ Pomeranian District Division and the Grunwald leaders who had been forced to leave Pomerania and find refuge in Warsaw joined the combat unit of KOP operating there. Particularly intense was the KOP intelligence cooperation with ZDZ and with an intelligence organization called Muszkieterzy (Musketeers) led by the engineer Stefan Witkowski who relatively quickly established its organisational network in the lands annexed to the Reich. Thus, the intelligence gathered by the members of KOP Pomeranian District Division was transmitted not only to Warsaw but also to the West, first to France and then to the UK. Some of it was published by KOP in Polska Żyje (Poland Lives), an extremely popular clandestine newspaper especially in the first months of the Nazi occupation of Poland. The lack of relevant documentation and the fact that many KOP members who had played an important role in the resistance movement in Pomerania did not survive the war, make it impossible to give a comprehensive overview of the underground activity in Pomerania. Given the exceptionally difficult conditions enforced by the Germans in Pomerania, however, there is a lot to suggest that the underground activists managed to create a well-functioning organizational structure of KOP.

They organized a well-functioning system of communication both within Pomerania as well as between Torun and Warsaw hosting the Headquarters of KOP, Inspektorat Ziem Zachodnich (Inspectorate of the Western Territories), and from the spring of 1940, the Headquarters of KOP Pomeranian District Division from Warsaw flowed orders, instructions and assignments, whereas from Pomerania: not only dispatches but also all kinds of reports which were of particular significance in the early days of the German occupation, when the underground structures in the western territories incorporated into the Reich were not yet developed; therefore, the secret intelligence disseminated by KOP was extremely valuable. The charitable activity conducted alongside and mainly benefitting families that had found themselves in the most difficult situation served as a cover the true purpose of the organization. Little or no previous experience in and knowledge of methods of underground activity, including those in- 
volving outreach and recruitment of new members, as well as too wide distribution of clandestine press, all resulted in the Gestapo tracking some underground activists down in Torun and making their first arrests also among KOP members as early as March 1940. The betrayal by a liaison of KOP Pomeranian District Division, Władysław Jędrzjewski, and his collaboration with the Gestapo resulted in the break up not only of the KOP Pomeranian District Division but also in tracking down their contacts in Warsaw and making arrests there of KOP activists and many others associated with this organization. An intensive Gestapo investigation led to further arrests among KOP members. Through torture-interrogation the Gestapo gained a wealth of top secret information on the structure of the organization. Due to the passage of time researchers into the history of KOP Pomeranian District Division have failed to give a complete picture. There are no accounts of some important episodes. What is somewhat better documented, however, is the course of the Gestapo investigation, although little is known about how and why Władysław Jędrzejewski started collaborating with the Gestapo. The arrested members of the KOP Pomeranian District Division underwent brutal interrogations at the Gestapo in Grudziądz as did the members of ZWZ Pomeranian District Division also arrested in the autumn of 1940. Upon the completion of the investigation, they were sent to Stutthof internment camp to be later transported to other concentration camps in the Reich. Immediately after the war former members of KOP from Pomerania hardly ever got involved in veteran support activities. Some wrote a few reports (which was quite an exception) but none of the reports have survived. Much later, starting in the late 1960s, they began revealing information on their former involvement in KOP. That reluctance to share information was certainly caused by the fact that the Second Commander of KOP, Henryk Bogucki, was kept in prison run by Urzad Bezpieczeństwa (UB / Secret Political Police) for many years. He was initially convicted on charges of cooperation with British intelligence and later: on collaboration with the Gestapo, which cast a shadow on the entire organization. While in prison, Bogucki not only testified but he also, quite voluntarily, wrote his own lengthy account of KOP (and later: Polska Armia Ludowa (PAL/Polish Peo- 
ple's Army)) in 1939-45 but there is a lot of fabrication in these accounts. Bogucki included only perfunctory remarks while referring to the KOP Pomeranian District Division. Released from prison in May 1956, Bogucki undertook the task of collecting material about the structures KOP not only in Warsaw but also elsewhere Poland. As far as Pomerania is concerned, however, he failed to collect much relevant material. Consequently, after the war there was no-one who, having been a high-ranking member of KOP in Pomerania and thus familiar with its structure, could have easily obtained relevant information about underground activities of KOP Pomeranian District Division. Tadeusz Odrowski, who was best equipped to become the chronicler of this region, did not return to Pomerania after the war. He lived in Wrockaw and, fearing arrest by UB, broke all contact with the former members of KOP in Pomerania. He died there in September 1957, when KOP still remained outside the professional interests of Polish historians. Odrowski did not leave any report or memoir devoted to his KOP activities. Therefore, it is safe to conclude that very little is known about KOP Pomeranian District Division. KOP still remains in our consciousness as a former fairly large nationwide underground organization still waiting for a monograph, and indeed for a historian who will have to do with material with varying degrees of credibility, including myths and fabrication, and at the same time attempt to determine the nature of the organisation's factual performance through separating fiction and legend from factual, often dramatic events while at the same time critically assessing certain activities carried out by the organization and its members who played very important roles within its structure. This will certainly turn out to be an extremely difficult task, even for a researcher with many years of experience and expertise in the field of underground struggle carried on in the years 1939-1945.*

* The author is currently preparing for publication a book on Komenda Obrońców Polski (KOP/ Headquarters of the Defenders of Poland - Polska Armia Ludowa (PAL/ Polish People's Army); this is not going to be a monographic stu, however, but a study of KOPPAL, because there are too many cases were events are mentioned in one source only, and on top of that - a quite peculiar one, which rules out both their verification and objective presentation. 


\section{BIBLIOGRAPHY}

(selection)

\section{ARCHIVE SOURCES}

\section{Archiwum Akt Nowych w Warszawie}

Akta Delegatury Rządu RP na Kraj, Departament Spraw Wewnętrznych, mf $2225 / 10$ II

Fundacja Generał Elżbiety Zawackiej. Archiwum i Muzeum Pomorskie Armii Krajowej oraz Wojskowej Służby Polek

Komenda Okręgu, teczki osobowe (dalej cyt.: t. os.):

Lendzion Witold, sygn. M 393/1016 Pom.

Inspektorat Brodnica, t. os.:

Porada Konrad, sygn. M 350/962 Pom.

Inspektorat Chojnice, t. os.:

Szczęsny Bernard, sygn. M 421/1047 Pom.

Inspektorat Toruń, t. os.:

Dziarnowski Franciszek sygn. M 711/1380 Pom.

Jackowiak Zofia, sygn. K 157/157 Pom.

Modrzyńska Honorata, sygn. K 524/524 Pom.

Obiegałka Stanisław, sygn. M 185/794 Pom

Stremlau Wiesław, sygn. 1577/2508 Pom.

Inspektorat Włocławek, t. os.:

Augustowska-Ostrowicka Helena, sygn. K 192/192 Pom.

Michalska Aurelia, sygn. K 494/494 Pom.

Nowacka-Wyględowska J., sygn. K 769/1906 Pom.

Pluskota Władysław, sygn. M 351/963 Pom.

Stankiewicz Zbigniew, sygn. M 85/694 Pom.

Szczepański Henryk, sygn. M 307/918 Pom. 
Zalewska Bolesława, sygn. K 340/340 Pom.

Zaleski Tadeusz, sygn. M 11/620 Pom.

Kartoteka informacyjna, Inspektorat Włocławek: Tuszewski Marian

Teczka problemowa: Wojskowa Organizacja Ziem Zachodnich, sygn. I/10

\section{Archiwum Muzeum Stutthof}

Akta KL Stutthof (KLS):

Księga ewidencyjna, sygn. I-II-5

Podręczna kartoteka numerowa: Maria Socha nr 10521

sygn. I-III-11029, t. pers. Walentyny Narewskiej

sygn. I-III-6083, t. pers. Z. Jackowiak

sygn. I-III-13014, t. pers. M. Rokity

sygn. I-III-10054, t. pers. Izabeli Malejko

sygn. I-III-11029, t. pers. Walentyny Narewskiej

sygn. I-III-11927, t. pers. Zofii Piaseckiej

sygn. I-III-15011, t. pers. H. Stanke

sygn. I-III-55087, t. pers. Elżbiety Stremlau

sygn. I-III-12489, t. pers. Adama Przybyły

sygn. I-III-6398, t. pers. Władysława Jaworowskiego

sygn. Z-II-4-1

\section{Kolekcja Konrada Ciechanowskiego}

- Notatka z rozmowy z Aleksą Szewą z 29 VI 1961

- Notatka z rozmowy z H. Boruckim z dnia 16 XI 1965

- Notatka z rozmowy z F. Zilkem z 25 III 1963

- J. Iwańska, Życiorys Pawła Piątkowskiego, Szczecin 31 I 1974.

Listy funkcjonariusza gestapo F. Drewsa do H. Teuffla z 22 VIII 1943, 31 VIII 1943 i 7 IX 1943 (tłumaczenia)

Materiały W. Drygałowej (odpis)

Materiały S. Obiegałki

Chudy A., Cmentarz na Zaspie, maszynopis

Relacje: Teodora Regenta z 7 I 1981; A. Matuszak, Witolda Lendziona z 16 XI 1965, Hieronima Kmiecika z 13 IX 1990 
Sonderfahndungsbuch Polen, fotokopia

Wspomnienia, t. III, Henryk Trepczyk, Fakty i zdarzenia okresu międzywojennego. Kolejarze - ofiary wojny i masowych morderstw

Wspomnienia, t. XV, rel. M. Pitery-Zalewskiej

Wspomnienia, t. XVII, rel. E. Stremlau

Zeznania P. Rybickiego, Londyn 31 III 1944 (odpis)

\section{Archiwum Państwowe w Bydgoszczy}

AP Bydgoszcz, Materiały ZBoWiD Bydgoszcz, t. inw. 123, Wspomnienia z okresu okupacji 1939-1945; Mój udział w wojnie 1939-1945, rękopis

\section{Biblioteka Gdańska PAN}

Ms sygn. 5157, Starszoharcerski Krąg Instruktorski „Jaszczurka”. Harcerze bohaterzy Hufca ZHP w Tczewie polegli i pomordowani w latach II wojny światowej 1939-1945, Tczew 2 III 1975

\section{Instytut Pamięci Narodowej w Warszawie}

IPN BU, sygn. 0/330/246, t. 1-12

IPN BU, sygn. 0397/60, t. 2 (bez nazwy wypisy z materiałów H. Boruckiego) IPN 0397/60, t. 4

IPN BU, sygn. 0207/7918, Akta placówki gestapo w Ciechanowie

IPN BU, sygn. Wr 21/1619, Akta Wojskowego Sądu Rejonowego we Wrocławiu w sprawie przeciwko T. Pomian-Odrowskiemu

IPN BY, sygn. 85/356, Prokuratura Sądu Okręgowego w Toruniu, Akta w sprawie przeciwko Sergiuszowi Kosteckiemu

IPN BY, sygn. 66/1873

IPN BY, sygn. 044/335, t. 1

IPN BY, sygn. 044/339, t. 2, Protokół przesłuchania Waltera Ziesnera z 18 VII 1952

IPN BU GK, sygn. 927/3123; OKBZH, Protokół przesłuchania świadka B. Domżalskiego, Bydgoszcz 10 I 1974

IPN BU GK, sygn. 379/3, Akta sprawy B. Czołby

IPN BU GK, sygn. 165/29

IPN Ol, sygn. 44/5-6 


\section{SOURCE PUBLICATIONS}

Armia Krajowa w dokumentach 1939-1945, t. I-VI, Londyn 1970-1989, reedycja krajowa: Wrocław 1990-1991.

Konferencja belgradzka w 1940 r., oprac. J. Zamojski, Najnowsze Dzieje Polski. Materiały i studia z okresu II wojny światowej, t. X, Warszawa 1966

\section{CHRONICLES - MEMOIRS - ACCOUNTS}

Czuperska-Śliwicka A., Cztery lata ostrego dyżuru. Wspomnienia z Pawiaka 1940-1944, Warszawa 1965.

Gdynia 1939. Relacje uczestników walk lądowych, wstęp, wybór, komentarze W. Tym, A. Rzepniewski, Gdańsk 1979.

Landau L., Kronika lat wojny i okupacji, t. I, Warszawa 1962.

Leski K., Życie niewłaściwie urozmaicone. Wspomnienia oficera wywiadu i kontrwywiadu AK, wyd. I, Warszawa 1989.

Relacje członków konspiracji pomorskiej w latach 1939-1945, wyboru dokonała i opracowała E. Kwiatkowska-Dybas, Toruń 2000.

Roman W., Oficer do zleceń, Warszawa 1989.

Stremlau W., Uciekłem z Gestapo w Grudziądzu, Kombatant Grudziądzki. Jednodniówka ZBoWiD w Grudziądzu, IX 1984.

Wanat L., Za murami Pawiaka, Warszawa 1985.

\section{STUDIES AND MONOGRAPHS}

Augustowska H., Ostrowicki Alfons (1908-1943), członek KOP, żołnierz ZWZ-AK obw. Lipno, Warszawa, [w:] Słownik biograficzny konspiracji pomorskiej 1939-1945, cz. 3, Toruń 1997.

Bartoszewski W., Warszawski pierścień śmierci 1939-1945, Warszawa 1970.

Bauer P., Polak B., Armia Poznań w wojnie obronnej 1939, Poznań 1982.

Borodziej W., Terror i polityka. Policja niemiecka a polski ruch oporu w GG 1939-1944, Warszawa 1985.

Chrzanowski B., Delegatura Rządu na Kraj na Pomorzu. Nieznane karty z frontu walki cywilnej podczas okupacji niemieckiej i po jej zakończeniu, Toruń 2011.

Chrzanowski B., Laszenko Włodzimierz ps. „Jaskółka”, „Włodek” (19221982), członek KOP we Włocławku, ZWZ, „PLAN II”, WGW, ZPN, „MiP” $w$ Warszawie, komendant Podokręgu Łódzkiego (kujawskiego) ZORMiP, 
[w:] Słownik biograficzny konspiracji pomorskiej 1939-1945, cz. 3, Toruń 1997.

Chrzanowski B., Lesikowski Stanisław ps. „Las” (1906-1944), kmdt Okregu Kościerskiego PAP i Obw. Kościerzyna AK, [w:] Słownik biograficzny konspiracji pomorskiej 1939-1945, cz. 3, Toruń 1997.

Chrzanowski B., Miecz i Pług (Zjednoczone Organizacje Ruchu Miecz i Pług) na Pomorzu w latach okupacji niemieckiej 1939-1945, Torun 1997.

Chrzanowski B., Organizacja i funkcjonowanie systemu łączności pocztowokurierskiej i wywiadowczej na odcinku Wybrzeże Gdańskie-Szwecja, [w:] Z dziejów Wydziału Łączności Zagranicznej Komendy Głównej ZWZ-AK „Zagroda”, Toruń 1999.

Chrzanowski B., Paweł Piatkowski, [w:] Zastużeni Pomorzanie w latach II wojny światowej. Szkice biograficzne, Wrocław 1984.

Chrzanowski B., Stanisław Lesikowski (1906-1944) działacz organizacji podziemnej Polska Armia Powstania i Armii Krajowej, [w:] Zasłużeni Pomorzanie w latach II wojny światowej. Szkice biograficzne, WrocławWarszawa-Gdańsk-Łódź 1984.

Chrzanowski B., Wrzesień 1939 i początki Polskiego Państwa Podziemnego na Pomorzu, [w:] Warszawa i stolice regionalne II RP we wrześniu 1939 roku $i$ w poczatkach Polskiego Państwa Podziemnego, pod red. M. M. Drozdowskiego i H. Szwankowskiej, Warszawa 2002.

Chrzanowski B., Zwiazek Jaszczurczy i Narodowe Siły Zbrojne na Pomorzu 1939-1947, Toruń 1997.

Chrzanowski B., Gąsiorowski A., Steyer K., Polska Podziemna na Pomorzu w latach 1939-1945, Warszawa 2005.

Ciechanowscy K. K., Tajna działalność kulturalno-oświatowa na Pomorzu w latach 1939-1945, Gdańsk 1975.

Ciechanowski K., Gajewski Wilhelm ps. „Niut”, „Piorun” (1916-1944), kierownik Biura Kdy TOW GP na pow. Tczew, [w:] Słownik biograficzny konspiracji pomorskiej 1939-1945, cz. 1, Toruń 1994.

Ciechanowski K., Ruch oporu na Pomorzu Gdańskim 1939-1945, Warszawa 1972.

Czapska-Jordan W., WRN. PPS pod okupacja niemiecka 1939-1945, Londyn 1976.

Domańska R, Pawiak więzienie gestapo. Kronika 1939-1944, Warszawa 1978. 
Dunin-Wąsowicz K., Polski ruch socjalistyczny 1939-1945, Warszawa 1993.

Duraczyński E., Kontrowersje i konflikty 1939-1941, Warszawa 1977.

Dziarnowski F., Głosy w dyskusji, [w:] Pomorskie organizacje konspiracyjne poza AK 1939-1945, Torun 1994.

Encyklopedia II wojny światowej, Warszawa 1975.

Encyklopedia Gdyni, Gdynia 2006.

Gąsiorowski A., Geneza i początki ruchu oporu na Pomorzu Gdańskim, Gdańsk 1991.

Gąsiorowski A., Hulewicz Piotr ps. „Jastrzą” (1913-1955), kmdt Rejonu Gdyńskiego PAP, następnie Okręgu Morskiego PAP w Gdyni, [w:] Słownik biograficzny konspiracji pomorskiej 1939-1945, cz. 3, Torun 1997.

Gąsiorowski A., Jan Kaszubowski i służby specjalne. Gestapo - Smiersz UB..., Gdańsk 2008.

Gąsiorowski A., Jarzębowski Jan ps. „Okon’” (1898-1974), kmdt Inspektoratu Wybrzeże, [w:] Słownik biograficzny konspiracji pomorskiej 1939-1945, cz. 1, Toruń 1994.

Gąsiorowski A., Polska Armia Powstania. Największa tajemnica pomorskiej konspiracji, Torun 1997.

Gąsiorowski A., Szare Szeregi na Pomorzu 1939-1945, Toruń 1998.

Gąsiorowski A., Teodor Czecholiński..., [w:] Zasłużeni Pomorzanie w czasie drugiej wojny światowej, Gdańsk 1988.

Gąsiorowski A., Steyer K., Tajna Organizacja Wojskowa „Gryf Pomorski”, Gdańsk 2010.

Gliński M., Organizacja i struktura obozu Stutthof, [w:] Stutthof. Hitlerowski obóz koncentracyjny, Warszawa 1988.

Głębowicz B., Okupacja hitlerowska 1939-1945, [w:] Monografia Brześcia Kujawskiego, pod red. B. Głębowicza, Włocławek 1970.

Grabowska J., Więźniowie, [w:] Stutthof. Hitlerowski obóz koncentracyjny, Warszawa 1988.

Grabowski, Polska tajna administracja cywilna 1940-1945, Warszawa 2003.

Grochowina S., Sziling J., Barbarka. Miejsce niemieckich egzekucji Polaków z Torunia i okolic (październik-grudzień 1939), Toruń 2009.

Honkisz T., Zrzeszenie „Wolność i Niezawisłość”, [w:] Armia Krajowa. Dramatyczny epilog, Warszawa 1994. 
Jacobmeyer W., Heimat und Exil. Die Anfänge der polnischen Untergrundbewegung im Zweiten Weltkrieg, Hamburg 1973.

Jankowski J., Harcerstwo Pomorza Gdańskiego i Kujaw 1911-1945, Toruń 1988.

Jastrzębski W., Tadeusz Kaube (1921-1942), [w:] Zasłużeni Pomorzanie w czasie drugiej wojny światowej, Gdańsk 1988.

Jastrzębski W., Terror i zbrodnia. Eksterminacja ludności polskiej i żydowskiej w rejencji bydgoskiej w latach 1939-1945, Warszawa 1974.

Jastrzębski W., Sziling J., Okupacja hitlerowska na Pomorzu Gdańskim w latach 1939-1945, Gdańsk 1979.

Jaszowski T., Gestapo w walce z ruchem oporu nad Wisłą i Brdą, współpraca autorska: W. Jastrzębski, Bydgoszcz 1989.

Jaszowski T., Okręg Pomorski Armii Krajowej.Podokręg Południowo-Wschodni ZWZ-AK, Toruń 1996.

Jaszowski T., Piątkowski Paweł ps. „Podchorążak”, przybr. nazw. „Wyleżyński”, „Ziótkowski” (1916-1942), komendant Pomorskiego Okręgu KOP, [w:] Słownik biograficzny konspiracji pomorskiej 1939-1945, cz. 2, Toruń 1996.

Juszkiewicz R., Mławskie Mazowsze w walce, Warszawa 1968.

Kobylańska Z., Konfederacja Narodu w Warszawie, Warszawa 1999.

Komorowski K., Konspiracja pomorska 1939-1947. Leksykon, Gdańsk 1993.

Komorowski K., Polityka i walka. Konspiracja zbrojna ruchu narodowego 1939-1945, Warszawa 2000.

Krajewski K., Uderzeniowe Bataliony Kadrowe 1942-1944, Warszawa 1993.

Kunert A. K., Ilustrowany przewodnik po Polsce Podziemnej 1939-1945, Warszawa 1996.

Kunert A. K., Słownik biograficzny konspiracji warszawskiej 1939-1944, t. 1, Warszawa 1987.

Lewandowska S., Polska konspiracyjna prasa informacyjno-polityczna 19391945, Warszawa 1982.

Malinowski K., Tajna Armia Polska. Znak. Konfederacja Zbrojna. Zarys genezy, organizacja i działalność, Warszawa 1986.

Matusak P., Ruch oporu w Polsce 1939-1945, Katowice 1987. 
Ney-Krwawicz M., Komenda Główna Armii Krajowej 1939-1945, Warszawa 1990.

Obozy hitlerowskie na ziemiach polskich, Warszawa 1979.

Olstowski P., Obóz pomajowy w województwie pomorskim w latach 19261939, Warszawa 2008.

Olstowski P., Obóz Zjednoczenia Narodowego na terenie województwa pomorskiego. Zarys organizacji i działalności w pierwszym okresie istnienia (marzec 1937-luty 1938), [w:] Polska bez marszałka. Dylematy piłsudczyków po 1935 roku, zbiór studiów pod red. M. Wołosa i K. Kani, Toruń 2008.

Oracki T., Słownik biograficzny Warmii, Mazur i Powiśla XIX i XX wieku (do 1945 roku), Warszawa 1983.

Owsiński M., Polscy więźniowie polityczni w obozie Stutthof 1939-1945, Toruń 2001.

Piotrowski J., Piłsudczycy bez lidera, Toruń 2004.

Pluta-Czachowski K., Organizacja Orła Białego, Warszawa 1987.

Polak B., Powstańczy rodowód polskiej konspiracji wojskowej w Wielkopolsce 1939-1942, [w:] Z dziejów konspiracji wojskowej na tzw. ziemiach wcielonych do Rzeszy 1939-1945, Koszalin 1988.

Polska Partia Socjalistyczna w latach wojny i okupacji 1939-1945, t. 1-2, Aneks, Warszawa 1995.

Polskie Siły Zbrojne w drugiej wojnie światowej, t. III: Armia Krajowa, Londyn 1950.

Starczewski M., Współpraca członków sieci dywersji pozafrontowej z organizacjami paramilitarnymi i społecznymi w Wolnym Mieście Gdańsku, [w:] Organizacje paramilitarne i pokrewne w przededniu II wojny światowej, Toruń 1996

Sziling J., Polityka okupanta hitlerowskiego wobec Kościoła katolickiego 1939-1945, tzw. Okręgi Rzeszy: Gdańsk-Prusy Zachodnie, Kraj Warty i rejencja katowicka, Poznań 1970.

Ślaski J., Polska Walcząca (1939-1945), t. I-III, wyd. 3, Warszawa 1999.

Terej J. J., Na rozstajach dróg. Ze studiów nad obliczem i modelem Armii Krajowej, wyd. drugie poprawione i uzupełnione, Wrocław-Warszawa-Kraków-Gdańsk 1980.

Turlejska M., Spór o Polskę. Szkice historyczne, Warszawa 1972. 
Wieczorkiewicz P., Historia polityczna Polski 1935-1945, Warszawa 2005.

Woźniak M., Dziarnowski Alfons Franciszek ps. „Głowacz”, przybr. nazw. „Karol Szubert” (1910-1995), oficer WP, WOW-WOZZ, [w:] Słownik biograficzny konspiracji pomorskiej 1939-1945, cz. 3, Toruń 1997.

Woźniak M., Okręg poznański, [w:] AK. Rozwój organizacyjny, Warszawa 1996.

Woźniak M., Poszwiński Adam, [w:] Encyklopedia konspiracji wielkopolskiej 1939-1945, red. M. Woźniak, Poznań 1998.

Woźniak M., Wojskowa Organizacja Ziem Zachodnich. Geneza - struktury - koncepcje - działalność (1940 r.), [w:] Pomorskie organizacje konspiracyjne poza AK 1939-1945, Toruń 1994.

Zakrzewska A., Przybyła Adam przybr. nazw. „Stefan Bywalec” (1907-1985), kmdt. Rejonowy KOP-Toruń, [w:] Słownik biograficzny konspiracji pomorskiej 1939-1945, cz. 4, Toruń 1998.

Ziółkowski B., Kujawski Związek Polityczno-Literacki i Kujawskie Stowarzyszenie Społeczno-Literackie na Kujawach Wschodnich w latach okupacji niemieckiej 1939-1945 (Działalność i losy konspiratorów), Torun 2006.

Ziółkowski B., Nowacka Jadwiga II v. Wyględowska, z d. Wojdyłło, ps. „Drzymała", przybr. nazw. Budzyńska (1912-2000), członkini Kujawskiego Związk Polityczno-Literackiego (KZPL), [w:] Słownik biograficzny konspiracji pomorskiej 1939-1945, cz. 6, Toruń 2004.

Ziółkowski B., Piętka Walenty ps. „Józef” (1899-1993), członek Komendy Obrońców Polski (KOP), Kujawskiego Stowarzyszenia Społeczno-Literackiego (KSSL) i Obw. AK Włocławek, [w:] Słownik biograficzny konspiracji pomorskiej 1939-1945, cz. 6, Toruń 2004.

Zofia Kossak, pr. zb., Warszawa 1992.

\section{ARTICLES}

Barganowski A., Plebiscyt na Ziemi Kwidzyńskiej, Zeszyty Kwidzyńskie, 2000, nr 1 pt. Plebiscyt na Powiślu - 11 lipiec 1920 roku.

Borucki H. ps. „Czarny”, O powstaniu i działalności propagandowej KOP, Wojskowy Przegląd Historyczny, 1968, nr 4.

Chrzanowski B., Organizacja sieci przerzutów droga morska z Polski do Szwecji w latach okupacji hitlerowskiej (1939-1945), Stutthof. Zeszyty Muzeum, nr 5, 1984. 
Dobroszycki L., Sprawa płk. dypl. Janusza Albrechta w świetle źródeł niemieckich, Wojskowy Przegląd Historyczny, 1960, nr 1.

Fijałkowski T., O mławskim Mazowszu w latach drugiej wojny światowej, Wojskowy Przegląd Historyczny, 1970, nr 3.

Jaworski C. W. ps. „Dr Sas”, O działalności organizacji „Polska Niepodległa” w czasie okupacji hitlerowskiej, Wojskowy Przegląd Historyczny, 1968, nr 1.

Jezierska M. E., Kary obozowe na podstawie dokumentów obozu koncentracyjnego Stutthof, Stutthof. Zeszyty Muzeum, 1990, nr 9.

Kazimierczak A., O gdyńskim ruchu oporu w latach hitlerowskiej okupacji, Jantarowe Wici, 1976, nr 12

Łabędzki Z., „Blindziarze”, Wieczór Wybrzeża, 1962, nr 304-305.

Łabędzki Z., Czarne zjawy na trasie Gdynia-Szwecja, Kulisy, 1964, nr 48.

Łabędzki Z., Niezwykła historia z lat okupacji. Punkt etapowy nad ekranem, Wieczór Wybrzeża, 1963, nr 72.

Malanowski Z. ps. „Prus”, „Turkus”, Jeszcze raz w sprawie KOP, Wojskowy Przegląd Historyczny, 1971, nr 1.

Mulak J., Komenda Obrońców Polski (KOP) na wzór POW, Dzieje Najnowsze, 1988, nr 1.

Paśnik J., Hitlerowska policja bezpieczeństwa w Generalnym Gubernatorstwie, Wojskowy Przegląd Historyczny, 1986, nr 4.

Pluta-Czachowski K., W sprawie konspiracyjnej organizacji „Komenda Obrońców Polski”, Wojskowy Przegląd Historyczny, 1968, nr 3.

Rzepecki J., Jeszcze o organizacji KOP, Wojskowy Przegląd Historyczny, 1969, nr 1.

Rzepecki J., Kierownictwo polityczne polskiego podziemia wojskowego w latach 1939-1941, Przegląd Historyczny, 1974, nr 1.

Sierchuła R., Formacje wojskowe Narodowej Demokracji w Wielkopolsce w latach 1939-1949, Życie i Myśl, 1994, nr 14.

Tarnogrodzki T., Tryc R., Polskie organizacje konspiracyjne w kraju w latach 1939-1945, Wojskowy Przegląd Historyczny, 1966, nr 4.

Tylza W., Likwidacja „Grunwaldu”, Pomorze, 1966, nr 10.

Tyszewicz J., Stalag XX A. Obóz jeńców wojennych w Toruniu w latach 19391945, Zapiski Historyczne, T. XLI, 1976, z. 1. 
Wiśniewski M., Jeszcze o organizacji „Komenda Obrońców Polski”. W odpowiedzi płk. dypl.w st. sp. dr. Janowi Rzepeckiemu, Wojskowy Przegląd Historyczny, 1968, nr 1.

Wiśniewski M., Z historii powstania i działalności Komendy Obrońców Polski, Wojskowy Przegląd Historyczny, 1967, nr 3.

Wójtowicz N., Jeszcze o świadectwie życia Zofii Kossak, Nasz Głos, 2007, nr 8-9, s. 25-26.

\section{UNDERGROUND PRESS}

„Polska Żyje” (1939-1944)

„Kurier” [KOP-PAL] (1943)

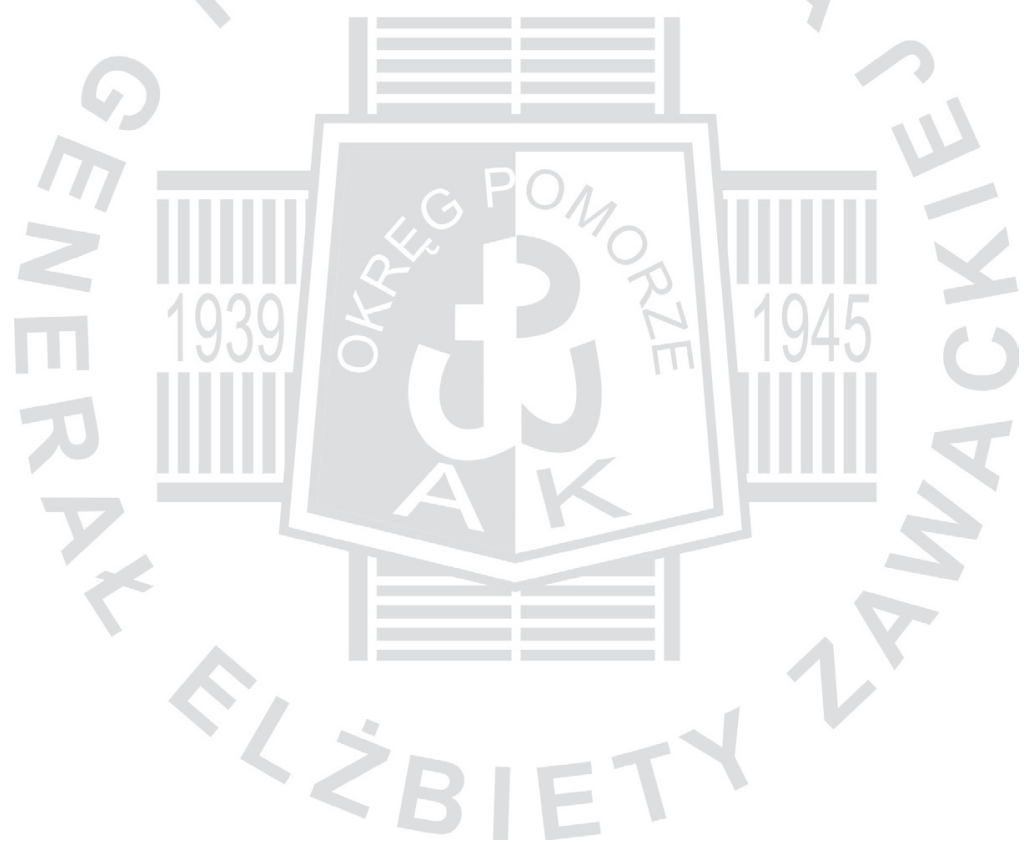




\section{PERSONAL INDEX}

“37” see: Leski Kazimierz

"Adamski" see: Antczak Antoni

Albrecht Janusz "Wojciech" 22

Aleksanderowicz "As" 41

Antczak Antoni "Adamski”, "Ida” 63, 70

Antoszewski Stanisław "Krzywousty” 29

"As" see: Aleksanderowicz

Autenreib 107

Babinicz Stanisław 121

Bachliński Bronisław "Wyrwa” 29

Barganowski A. 58

Bartoszewski W. 111-112

Basiński 50, 52

Baszanowska Klara 121

Bauer P. 59

"Beni" see: Porożyński Benedykt

"Beno" see: Szczęsny Bernard

Bereuter 111

Bieńkowski

- Józef “Ostoja” 124-125

- Witold "Dr Kalski”, "Jan”, "Kalski”, "Wencki” 50

Blikle 63

"Błysk" see: Chrostowski Michał

Bobrzyk Edmund "Bóbr" 29

Bogobowicz Jan "Janusz Wacławski”, “Litwin", "Kapucyn" 110-111

"Bolesław” see: Chyliński Józef

Bołtuć

- Maria "Marianna”, "Mutka” 85, 109, 113, $116,118-119$

- Mikołaj 85

"Bończa" see: Cerklewicz Marceli

Borkiewicz Adam 18-19

Borkowski Kazimierz see: Pluta-Czachowski Kazimierz

Borowy Wacław 51-52
Borucki Hanryk “Czarny”, false name: Alfred Rawski 9, 12, 20-22, 25-33, 35-37, $41,44,47,49,53,64,82,86-89,110-$ $113,116,129-130$

Borysiak Stanisław 59, 62

Broza Franciszek Izydor 82

"Bóbr" see: Bobrzyk Edmund

"Bradl" see: Leski Kazimierz

"Brand" 86

"Bronek" see: Kotnowski Bronisław

"Brzezina" see: Stremlau Wiesław

"Brzoza" see: Daremniak Wincenty

Brzozowski 116

Budkiewicz 122

Bukiewicz Wanda 111

Burdyńska 89

“Bydgoski” see: Felczak Zygmunt, Kordowski Antoni

"Bywalec Stefan" see: Przybyła Adam

Cerklewicz Marceli "Bończa”, “Juliusz", "Marian", "Paszota" 43, 27, 70, 86, 88, 111

Chełstowski 59

Chmielnicka Jadwiga 39

Chmielnicki

- Antoni 39

- Wincenty 39

Chromiński Zygmunt "Lukasz” 32

Chrostowski Michał "Błysk" 30

Chrzanowski B. 12, 55, 62-63, 77, 81, 121

Chrzanowski Teofil 79

Chyliński Józef “Bolesław” 70

Ciechanowska K. 94

Ciechanowski K. 11, 44, 53, 63-64, 77, 94, $104,112,121$

Ciesielski

- family 69

- Wacław "Roman" 70 
Ciężnikowski Władysław see: Ziesner Walter

"Colonel" 89

Czachowski K. see: Pluta-Czachowski K.

Czajkowska 118

Czarliński 96

Czarnecka Jadwiga 123

"Czarny" see: Borucki Henryk, Kostecki Sergiusz, Tuszyński Marian

Czerniawska Jadwiga 51

Czuperska-Śliwicka A. 116, 120

Czyżniewski Edmund 111

Dalkowski family 69

Dankowski Franciszek 124

Daremniak Wincenty "Brzoza" 27, 31, 88, 110,112

Daszkowska Wanda 124

Dawidowski 57, 62

- Henryk 62

"Dębno" see: Krzyżanowski Edmund

Dębski Kazimierz 118

Dobroszycki L. 23, 52

Domańska R. 109, 111

Domżalska Wiktoria nee Stawska 68

Domżalski

- Bernard 68, 72, 103

- Jan 68

Donimirski 96

"Dr Kalski" see: Bieńkowski Witold

"Dr Sas" see: Jaworski C. W.

Drozdowski M. M. 56

Dubois Stanisław 21, 27

Dulski J. 124

Duszyński 101

Działowski 96

Dziarnowska

- Alicja 73

- Maria 73

Dziarnowski

- E. 73

- Franciszek "Głowacz" 72-73

"Dzwon" see: Saldat Jan

Dzwoniarek Antoni 59

Ejsmont Tadeusz 31
Engler Eugeniusz 88-89

"Englert" see: Ratajczak Józef

Erlandsson Björn 121

Felczak Zygmunt "Bydgoski”, “Jasiński”, "Zygmunt” 62-63

Forster Albert 97

Frank J. 125

Fressing 114

Fulczyk Paweł 37-38

Gabrynowicz Jan 45

Gajewski Wilhelm 77

Galinat Edmund 66

Gąsiorowski A. 11-12, 27, 30, 39, 52, 56, $58,62,73,76-77,82-83,85,105$

Gaudasiński Henryk 31

Gawalska Stefania 75

Gawalski Bogdan 75, 111

Gelert 73

Geringer Waldemar 68, 72-75, 105, 111

Gieysztor 31, 33

Glinkowska Halina nee Stanke vel Stenke 46, 109, 116, 120

"Głowacz" see: Dziarnowski Franciszek

"Gołdyn" see: Pluta-Czachowski Kazimierz

Gorczyński Zbigniew "Rawicz", "Oporski” 111

"Góral" see: Kraszewski Franciszek

"Grab” see: Zieliński Józef

Grabowska J. 117

Grabowski W. 59, 62, 70

Grosik Barbara see: Straszewska Barbara

Grossy Jan 75

Gruss Józef "Stanisław” 87

"Grzegorz" see: Hulewicz Witold

Grzemski Ludwik 76

"Hanica" see: Pitera Maria

Hartleb Tadeusz 21, 31

Helmuth Stefan "Stefan” 112

Hertlem Tadeusz 51

Hitler Adolf 21

Hoffmann Bruno 59

Holz Wacław 103, 111 
Hulewicz

- Piotr "Jastrząb" 83

- Witold “Olwid”, “Grzegorz” 31, 50, 112

"Ida" see: Antczak Antoni

"Inżynier" see: Witkowski Stefan

Iwańska Jadwiga 57

Iwański 71

“Jacek" see: Jackowiak Zofia

Jackowiak

- Anna nee Śliwińska 70

- Marcin 70, 117

- Zofia “Jacek" 67, 69-70, 77-78, 89, 117118

Jackowska

- Kazimiera 92, 102, 117-118

- Zofia 91

"Jackowski” see: Piątkowski Paweł

Jacobmeyer W. 10

"Jan” see: Bieńkowski Witold, Krzyżak Jan,

Szczęsny Bernard

"Janek" see: Kostecki Sergiusz

Jankowska Maria 118

Jankowski J. 75-76, 105

"Janusz" see: Kmiecik Witold

Jarosiński Bolesław 126

Jaroszyński 27

"Jarząb" see: Ludwicki Stanisław

Jarzębowski Jan “Okoń” 83

"Jasiński” see: Felczak Zygmunt

"Jaskółka” see: Laszenko Włodzimierz

“Jastrząb” see: Hulewicz Piotr

Jastrzębski W. 11, 92, 95, 105

Jaszowski T. 11, 46, 57, 74, 92

"Jawor" see: Jędrzejewski Alojzy

Jaworowska Danuta 45

Jaworowski Władysław, false name: Zygmunt Kamiński 45, 69, 118

Jaworski C. W. “Dr Sas” 8

Jędrzejewski

- Alojzy “Jawor” 81

- Władysław "Ostoja” 91, 106-110, 113$114,121,129$

Jedwabna Urszula 118

Jeżewski Franciszek 79-80, 92-93
Joachimczyk 80

- Irena 118

Jonas 95

"Józef” see: Piętka Walenty

"Juliusz" see: Cerklewicz Marceli

"Junosza" see: Mazurek Stanisław

Jurkowski Zygmunt "Kulesza” 53

Kaczgórski 118

Kaczyński 122

"Kalski" see: Bieńkowski Witold

Kamiński

- Edmund 68, 118

- Zygmunt see: Jaworowski Władysław

Kampe Werner 99

Kania K. 67

"Kapucyn" see: Bogobowicz Jan

"Karolczak" see: Ratajczak Józef

Kasprzyk Józef 59, 62

Kaszubowski 61

Kaube Tadeusz 92

Kazimierczak A. 83

Kentzer 95

Klawikowski Józef 77

Kleeberg Franciszek 83

Klimczuk 63

"Kłoda” see: Słonicki Aleksy

Kłosowski Eugeniusz 124

Kmiecik

- Czesław 77, 106

- Hieronim 77-79, 106

- Witold "Janusz" 77-78, 106, 117, 119, 121

Kmiotek Leon "Pomian" 72

Kniaziołucki Zygmunt "Zygmunt” 29

Kobylańska Z. 28

Kohl 71

Kołaciński Lucjan 110

Komorowski K. 27, 42, 64

Konkolewska

- Maria 104

- Marta 105

"Konrad" see: Myśliwek Bernard

"Kony" see: Porada Konrad

Kordowski Antoni "Sędzia”, "Bydgoski” 27, 32 
Kossak-Szczucka Zofia 51

Kostecka Irena 64-65

Kostecki Sergiusz “Czarny”, "Janek” 64-66, 83

Kotnowski Bronisław "Bronek” 29

Kowalska Jadwiga 111

Kowalski Michał 124

Kozłowski Adam "Leszek” 65

Krajewski K. 28

Kraszewski Franciszek "Góral” 29

"Krauze” see: Ratajczak Józef

Krauze Wanda 123

Krawcowicz Maria see: Piskorska Maria

"Krawczyk" see: Lewandowski Stanisław

Królikowski 27

Kruszczyński Aleksander 76

Krzepkowski Mieczysław 51

"Krzywousty" see: Antoszewski Stanisław

Krzyżak Jan "Jan” 29

Krzyżanowski Edmund “Dębno” 41

"Kuczaba" see: Pluta-Czachowski Kazimierz

Kuczyńska 73

Kukliński Władysław 61

"Kulesza" see: Jurkowski Zygmunt

Kunert A. K. 15, 18-20, 51, 53, 62

Kuśmierek 86-87

- Aniela 46, 87-88, 120

Kwiatkowska-Dybaś E. 71

Kwiatkowski M. J. 52

Kwiatkowski Michał 92

Langman Ada see: Tołłoczko-Langman Ada

"Las" see: Lesikowski Stanisław

Laszenko Włodzimierz "Jaskółka”, "Włodek" 125

Laszuk Adam 66

Lech

- Benedykt 124

- Janina 124

Lendzion

- Aleksandra 102, 104

- Alfons 82

- Bolesław 74

- Jerzy “Źółw” 75, 76, 104-105, 111
- Maria 104

- Witold 66-67, 71-72, 74-76, 82, 89-92, 102, 104, 109, 116

Lesikowski Stanisław "Las" 81-82

Leski Kazimierz “37”, "Bradl” 87

"Leszek” see: Kozłowski Adam, Rosner Benn

Lewandowska S. 50, 52

Lewandowski

- Edmund 117

- Stanisław "Krawczyk" 111, 114

"Litwin" see: Bogobowicz Jan

Ludwicki Stanisław "Ziółkowski", "Jarząb" 32-33, 44

\section{Łaniecki}

- Dominik 121

- Leon 121

"Łukasz" see: Chromiński Zygmunt

Maćkowski Jan 61

Magenheim Stefan 51

Magielski W. 124

"Major Pokrzywka" see: Piątkowski Paweł

Malanowski Z. "Prus", "Turkus” 9, 29

Malejko

- Hanna 109

- Izabela 109, 116

"Malinowska Zofia" see: Turkowska Zofia

Malinowski K. 25-26, 28-29

Mańkowski Walerian 75

"Marek" see: Piątkowski Paweł

“Marian” see: Cerklewicz Marceli

"Marianna" see: Bołtuć Maria

Marlicz Adam 126

Maroszewski 75

"Marysia” see: Matuszak Anna

Marzejewski Alojzy 79-80, 92

Matusak P. 10-11

Matuszak Anna "Marysia" 69

"Mazur” see: Włoczkowski Tadeusz

Mazurek Stanisław “Junosza” 124

"Mechanik" 69

Menke 122

Merklejn 116

Michalska Aurelia 105 
Miłaszewska Wanda 51

Miłaszewski Stanisław 51

Mileski 64

Miłosz Czesław 50

Mincberg Krystyna 112

Mirecki Alfons 103, 111

Modrzyńska

- Eugenia 71

- Honorata 67, 71, 89, 102-103

Moraczewski Jerzy 44, 122

"Mściciel" see: Roskosz

Mulak J. 9-10, 18-19

"Mutka" see: Bołtuć Maria

Mysłakowski 95

Myśliwek Bernard “Konrad” 80

Narewska Walentyna 109, 119

Ney-Krwawicz M. 66

Niewiadomy Sylwester 117

"Nitecki Bohdan" see: Studziński Bolesław

Nowak J. 91

Obiegałka Stanisław “Poraj” 75, 90, 117, 121

"Odra" see: Odrowski Tadeusz

Odrowski Tadeusz "Odra", "Pomian", "Sok" $27,33,36,38,44,57-63,127,130$

"Okoń” see: Jarzębowski Jan

Olstowski P. 66-67

Olszewska „Tążyna” 126

Olszewski 121

- Józef 126

"Olwid" see: Hulewicz Witold

“Oporski” see: Gorczyński Zbigniew

Oracki T. 27, 60

Orlik-Rückemann Wilhelm 11, 14-17

Ossowski 96

“Ostoja” see: Bieńkowski Józef, Jędrzejewski Władysław

Pansramm Franz 89-90

"Paparzyca" see: Pluta-Czachowski Kazimierz

"Pasek" see: Włoczkowski Edward

"Paszota" see: Cerklewicz Marceli

Pawłowicz Władysław 77
Pelle (Perle) 121

Perle see: Pelle

Piasecka Zofia 117

Piątkowska

- Agnieszka 103, 115

- Gertruda see: Pohl Gertruda

- Jadwiga 108

- Urszula 103

- Zofia 103-104

Piątkowski Paweł „Jackowski”, „Marek”, „Major Pokrzywka”, „Podchorążak”, false name Zbigniew Wyleżyński 32, 45-46, 55-57, 63-64, 66-69, 71, 81-82, 85-89, 102-104, 106-109, 112-113, 115-116, 119-120, 127

Piętka Walenty “Józef” 100, 125

Piłsudski Józef 16, 19

Piotrowski J. 67

Piskorska Maria nee Krawcowicz 118

Piskorski Marian 118

Pitera (Zalewska-) Maria „Hanica” 109, $113,116,118$

Pluta-Czachowski Kazimierz "Gołdyn", "Kuczaba", "Paparzyca”, false surnames: Kazimierz Borkowski, Władysław Rusinek 9, 14-17, 19

"Podchorążak" see: Piątkowski Paweł

Pohl

- Gertruda Jadwiga nee Piątkowska 71-72

- Jadwiga 46

Polak B. 59

"Polikowski" see: Staniszewski Wincenty

"Pomian" see: Kmiotek Leon, Odrowski Tadeusz

Porada Konrad "Kony" 76, 104

"Poraj" see: Obiegałka Stanisław

Porożyński

- Benedykt "Beni" 62-63

- Czesław 59

Poszwiński Adam 59

Próchnik Adam 51

"Prus", see: Malanowski Z.

Przyborowski K. 58

Przybyła Adam "Bywalec", "Stefan Bywalec" 68-70, 91, 117-118, 121

Przybylska Jadwiga 112 
Raczek family 125

Raczkiewicz Władysław 52

Radziwiłł 118

Ratajczak Józef "Englert”, "Krauze”, "Karolczak" 70

"Ratkowski" see: Rettinger Wilhelm

"Rawicz" see: Gorczyński Zbigniew

Rawski Alfred see: Borucki Hanryk

Regent

- Tadeusz 58

- Teodor 59, 61-63

Rettinger Wilhelm "Ratkowski” 115

Riess 96

Rochowiak Franciszek 63

Roguski Adam 116

Rokita Maksymilian 79-80, 92, 119

"Roman" 86, see also: Ciesielski Wacław

Roskosz "Mściciel” 29

Rosner Benn "Leszek” 29

Rudzki family 25

Rusinek Władysław see: Pluta-Czachowski Kazimierz

"Ruszczyc" 86

Rückemann Wilhelm see: Orlik-Rückemann Wilhelm

Rybicki Paweł 117, 120-121

Rydz-Śmigły Edward 21

Rygielska Władysława 118

Rzepecki J. 8-9, 53

Rzepniewski A. 83

Sałaciński Janusz "Szeliga” 29

Saldat Jan "Dzwon" 81

Schönfeld 122

Schräder Franz 107

Schulz Otto 111

"Sędzia" see: Kordowski Antoni

Siejkowski Wincenty 122

Sikorski Władysław 8, 10, 15, 22-23, 25, 52

Sitarz Franciszek 31

Skarsvag L. 121

Skerska E. 79

Skuratowicz Anna 112

Skwarczyński Stanisław 66

Słabędzki Mieczysław 59
Słonicki Aleksy “Kłoda” 35

Sobierajska Aleksa 104

Sobociński Marian 76, 104-105

Socha

- Alojzy 78, 91, 117, 121

- Maria 117-118

Sochacz Jan 112

"Sok" see: Odrowski Tadeusz

"Sokrates" see: Wieczorkiewicz M.

Sporny Leon 124

"Stanisław" see: Gruss Józef

Staniszewski Wincenty "Polikowski” 31

Stanke Halina see: Glinkowska Halina

Stankiewicz Zbigniew 101

Starczewski M. 40

Starzyński J. 117

Staszewski Karol 113, 116

Staśkiewicz Kazimierz 72

Stawska Wiktoria see: Domżalska Wiktoria

"Stefan" see: Helmuth Stefan

Stein Eugeniusz 124

Steinkraus 122

Stenke Halina see: Glinkowska Halina

Stępień Jan 102

Steyer K. 12, 62, 77

Straszewska (Grosik) Barbara 109, 116

Stremlau

- Elżbieta 119

- Wiesław "Brzezina” 75, 79-80, 89, 91-92, $104,118,121$

- Witold 117

Strzembosz T. 32

Studziński Bolesław "Bohdan Nitecki" 9, 14-17, 19-20, 22, 27, 30-32, 35, 39, 49, 57

Sucheński Jan 118

Szarota T. 53

Szczęsny Bernard "Beno", "Jan”, "Szulc" 79-80, 92-93

Szczucka Zofia see: Kossak-Szczucka Zofia

Szczuka 73

"Szeliga” see: Sałaciński Janusz

Szewa Aleksa „Wera” 72, 85

Sziling J. 11, 98

Szklennik Witold 25 
Szmidt Ryszard 31

"Szulc" see: Szczęsny Bernard

Szwankowska H. 56

Szwarc Franciszek 121

Szwejda Jan 110

Ślaski J. 11

Śledź Jan 121

Śliwińska Anna see: Jackowiak Anna

Śmigły Edward see: Rydz-Śmigły Edward

Święcicka Janina 31, 51

Świętochowski Ryszard 25-26

Tarnogrodzki T. 8

"Tążyna” see: Olszewska

Terej J. J. 10

Thielmann 102

Tołłoczko-Langman Ada 31

Tomczak Ignacy “Zawisza” 75

Tomczyk 80

Trapp Ferdynand 73

Trepczyński Franciszek 121

Tryc R. 8

Turczynowicz Danuta 124

Turkowska Zofia “Zosia”, "Zofia Malinowska" 46, 108

“Turkus” see: Malanowski Zygmunt

Turlejska M. 10

Tuszewski Marian 46, 69-70, 91-92, 104, 106, 117-118, 121

Tuszyński Marian “Czarny” 89, 91

Tym W. 83

Tyniec Józef 25

Venediger Günther 114

"Wacławski Janusz" see: Bogobowicz Jan

Walas 27

Waligórzanka Wanda 78

Wanat Leon 32

Wardecki Roman 31

Wasicki Jan 116

Wasilewski Leon 27, 43, 86, 112

"Wencki" see: Bieńkowski Witold

"Wera" see: Szewa Aleksa

Wersocki family 30
Widłaszewski Kazimierz 105

Wieczorkiewicz Mieczysław "Sokrates” 27, 35,88

Wiencek 95

Wierciński Andrzej 51

"Wir" 29

Wiśniewski 108

Wiśniewski M. 8-9, 23-24, 31, 35, 37-38, 40-41, 44, 50-51, 54, 57, 89, 111

Witkowski Stefan “Inżynier” 46, 86-89, 128

Witt 95

"Wludersag" see: Włodarczyk

Włoczkowski

- Edward "Pasek" 29

- Tadeusz "Mazur" 29

Włodarczyk

- Franciszek 118

- "Wludersag" 62

"Włodek" see: Laszenko Włodzimierz

"Wojciech" see: Albrecht Janusz

Wojdyłł Henryk 124

Wojtal 82

Wójtowicz N. 51

Wolniewicz 95

Wołos M. 66-67

Woźniak M. 59, 72

Wrycza 81

Wrześniak Wacław 100

Wyleżyński Zbigniew see: Piątkowski Paweł

"Wyrwa" see: Bachliński Bronisław

Zaborowski Alfons "Zgrzyb” 67-68, 71-75, $89,102,105,111$

Zagierski 76

Zakrzewska A. 68, 70, 91

Zalewska Bolesława 125

Zalewska-Pitera Maria, see: Pitera Maria

Zalewski Tadeusz 125-126

Zapporowitz 89

Zawacka Elżbieta “Zo” 7, 13

Zawicki Roman 125

"Zawisza” see: Tomczak Ignacy

Zdrojewski Leszek 76

“Zgrzyb” see: Zaborowski Alfons 
Zieliński

- Henryk 41

- Józef „Grab” 125

Zielke Franciszek 67

Ziesner Walter (Władysław Ciężnikowski) $106-108,115,122$

Zilke Franciszek 103

"Ziółkowski” see: Ludwicki Stanisław
Ziółkowski B. 12, 85, 100, 123

"Zo" see: Zawacka Elżbieta

"Zosia” see: Turkowska Zofia

"Zygmunt” see: Felczak Zygmunt, Kniaziołucki Zygmunt

“Żółw” see: Lendzion Jerzy

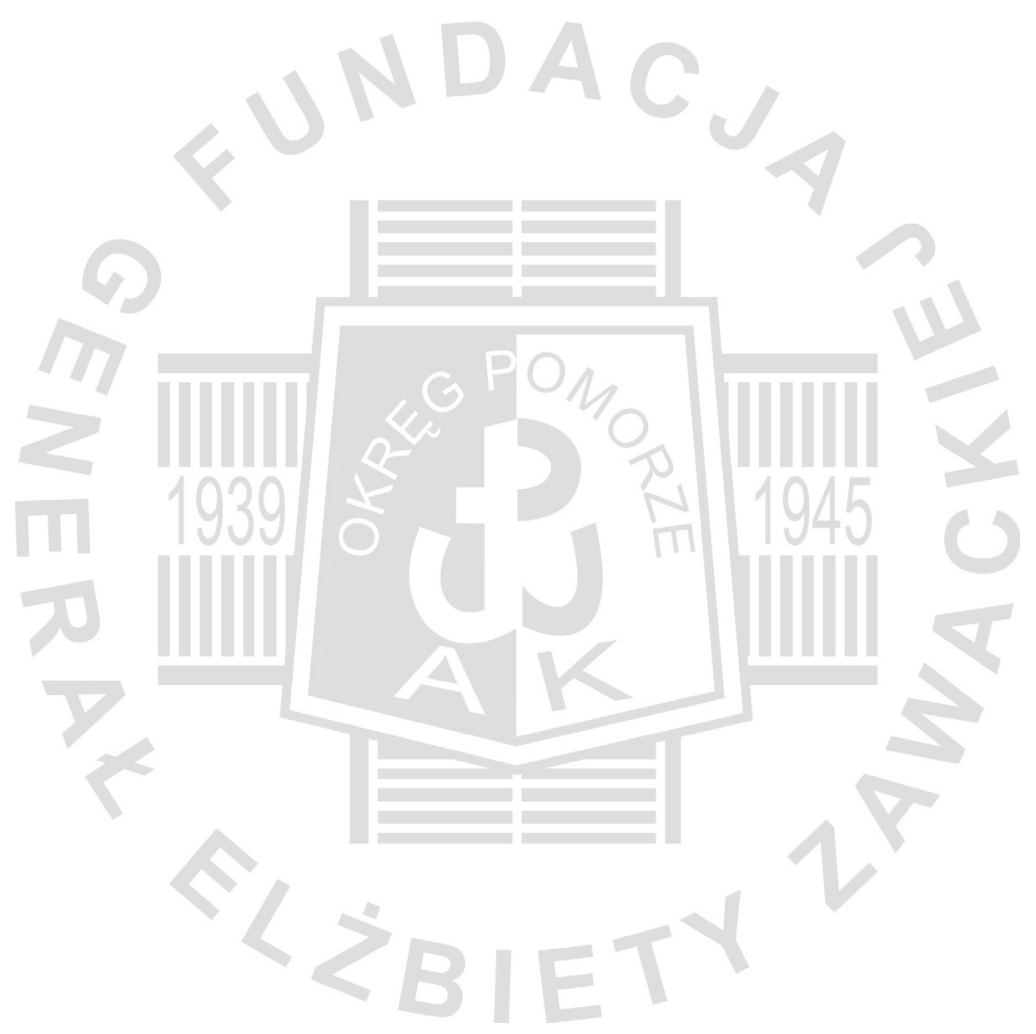




\section{INDEX OF GEOGRAPHICAL NAMES}

Aleksandrów Kujawski 85, 101, 125-126

America 96

Angers 26

Auschwitz see: Oświęcim

Babimost county 68

Bad Salzuflen 122

Bąk 81-82

Bartoszylas 82

Berlin 92-93, 119

Białystok 45

- district of KOP 38

Brodnica 75-76, 104-105, 111, 117-118

- county 69

- St.:

- - Kamionka 104

- - Łazienna 118

- - Ogrodowa 105

- - Przedzamcze 76

Brusy 80

Bug River 40-41

Bydgoszcz 42, 46, 59, 61-62, 68, 71, 75, 78 $95,99,102,105-106,111,117$

- Dworcowa St. 62

Celestynów 46, 108

Chełmno 42, 59-60, 65, 117

- county 65, 69

Chełmża (Kulmsee) 42, 64, 75-76, 121

- Dworcowa St. 64

Chile 27

Chojnice 43, 79-80, 92-93, 119

- country 79

- district ZWZ-AK 80

- Post-Stallstrasse 80

Chwarzno 82

Ciechanów 58

Ciechocinek 85

Cracow 17, 51-52, 112
- district of KOP 38

- territory ZWZ 15

Czarlin 78

Czernikowo 43, 107, 118, 121

Czersk 81

Danzig see: Gdańsk

Dirshau see: Tczew

Dubno 72

Działdowo 67

Europe Western 67, 128

France $23,52,82,96,128$

Garbatka 15

Garczyn 78

Gdańsk (Danzig) 43, 47, 65, 82, 91, 93, 114

- sub-district of KOP 43

- Western Prussia Reich District 69, 94

Gdingen see: Gdynia

Gdynia (Gdingen) 18, 43, 58, 82-83, 95, 98, 120-121

- Kamienna Góra (Steinberg) 120

- Korzeniowskiego St. (Prinz Eugenstrasse) 120

General Government 32, 35, 38, 41, 45, 53, $62,83-85,94,100,108,111,125$

- inspectorate of KOP 34, 38

Germany (Reich, Third Reich) 34-35, 40$41,45,47,53,86-88,93,95-96,100-$ $101,112,122,127-129$

Gniezno 68

Gniszewo 67, 70

Great Britain 51, 96, 128

Greater Poland see: Wielkopolska

Grudziądz 13, 43, 45-46, 58, 60, 66, 71, 73, 77, 91-92, 96-97, 102, 106-109, 112, $114-122,129$ 
- St.:

- - Amtstrasse 118

- - Młyńska (Königstrasse) 114, 117

Grupa 45

Hrubieszów 67

Hungary 10-11, 18

Igły 79

Inowrocław 43

Jarocin 62

Kaliningrad see: Królewiec

Kalisz county 46

Karsin 79, 81

Katowice 18

Kielce

- district of KOP 38-39

- voivodeship 116

Kiszewa Stara 81-82

Knybawa 77-78

Koło 46

- district of POW 18

Konarzyny 82

Kończewice 75, 117

Königsberg see: Królewiec

Königsdorf see: Królewo Malborskie

Konin 45

- district of POW 18

Kościerzyna 43, 80-82

- county (region) 81

Królewiec (Königsberg, Kaliningrad) 43, 92-93

Królewo Malborskie (Königsdorf) 78

Krzemieniewo 72

Kujawy (Kuyavia) 42, 85, 123

Kulmsee see: Chełmża

Kutno 38, 45-46, 62, 68-70, 78, 82, 100, 104, 118

- Toruńska St. 45

Kuyavia see: Kujawy

Kwidzyn (Marienwerder) 43, 114, 122

Laskowice 77

Lesleu see: Włocławek

\section{Leszno 68}

Lipno 43, 115, 117

- county 69, 98, 107, 115

London 7, 88, 121

Lubawa county 72

Lublin 16, 19-20, 30, 32, 35, 39

- area 38

- Bychawska St. 30

- country 39

- district of KOP 38-39, 52-54

Lviv 18, 40-41, 51, 109-110

- district of KOP 38

Lwów see: Lviv

Łódź 32-33, 51, 86

- district of KOP 32-33, 38, 42

- region 42

Łuck 72

Malbork (Marienburg) 78, 122

Marienburg see: Malbork

Marienwerder see: Kwidzyn

Masovia northern 41

Mauthausen 119

Mazury 36, 38, 60

Męcikał 80

Mińsk Mazowiecki 63

Mirakowo 68

Mołodeczno 68

Nessau see: Nieszawa

Nieszawa (Nessau) 100-101, 105, 126

- sub-district of KOP 85

Nowogród district of KOP 38

Okoniny 81

Olpuch 82

Osówka 115

Oświęcim (Auschwitz) 97

Palędzie 75

Palmiry 50, 111-112

Pelplin 77

Platerów 81

Płock

- district of KOP 32, 3842 
- region 42

Poland (Rzeczpospolita, polish state) 10, 13- 15, 18, 21, 24, 26, 32-35, 38, 40-41, $47,52,58,60-61,74,84,122,127-128$, 130

- Eastern Lands (E. Territories, areas under the Soviet occupation) 35, 38-41

- - inspectorate of KOP 34, 38

- People's Republic 39-40

- Western Lands (W. Territories, territories incorporated into the Reich) 35, 38, $41-42,53,87,95,99-100$

- - inspectorate of KOP 34, 38, 42, 44, 57, 122,128

Polesie district of KOP 38

Pomerania 7, 11-12, 27, 30, 32, 36, 38, 41, $43-44,46,55-56,58-67,70-71,75,78$, 80-81, 84-91, 93-101, 106, 108, 110, $112-114,117,119,127-130$

- district of:

- - DR 63

- - KOP 7, 11, 13, 38, 42-46, 53, 57, 63-64, 66-67, 71-72, 74-75, 80, 82, 84-86, 89, $92-95,101-104,112,116,120,127-$ 130

- - POW 15

- - ZWZ 56, 70, 87, 114, 128-129

- Eastern 89

- Western 63

- voivodeship 107-108

Powiśle 58, 60

Poznań 18, 44-46, 59, 61, 68, 70, 72

- county 75

- district of KOP 38, 42

- region 32, 42

Prussia

- Eastern 32, 42, 47, 127

- - sub-district of KOP 43

- Western 112

Radom 63

Ravensbrück 120

Reich see: Germany

Romania 10-11

Ruda 82
Rypin 43, 106-108, 114, 117-118

- county 69, 98

Rzeczpospolita see: Poland

Siberia 118

Siedlce 77

Silesia 32, 37-39, 41-42, 47, 52, 112

- district of KOP 38

- Lower 61

- territory of ZWZ 15

- Upper district of KOP 42

Słupca 45

Soviet Union 40, 54

Stanisławów district of KOP 38

Starogard 73, 82

Stutthof 65, 69-71, 79, 91, 106, 109, 118122,129

Sweden 121

Świecie 43, 59, 61, 77

- county 45

Tarnopol district of KOP 38

Tczew (Dirshau) 43, 46, 77-78, 91, 106, $117,119,121$

- county 67, 70

Third Reich see: Germany

Thorn see: Toruń

Toruń (Thorn) 11, 43-46, 55-57, 59, 63-77, 79-80, 85, 87-93, 95-97, 100-106, 109, $111,113,116-119,121-122,127-129$

- county $64,68,69,117$

- region (vicinities) 75

- Rudak 91

- St.:

- - Chopina 87

- - Kołłątaja 117

- - Łazienna 69, 102

- - Ogrodowa 70

- - Poznańska 103

- - Rybaki 72

- - Wysoka 69

- - Żwirki i Wigury 69

Tuchola 67

Tuczynek 51 
Vilnius 18, 40

- district of KOP 38

- region 68

Vistula River 33, 43, 91, 94

Volhynia 40, 77

- district of KOP 38

Wąbrzeźno 43, 73

- county 69

Warmia 36, 38, 58, 60

Warsaw 7, 12, 16-18, 20, 23, 25-29, 31-33, $35,38,41,43-46,50-51,53,56-58$, $60-67,70-73,75,77-79,81,84-92$, 96-97, 101-114, 116-117, 119-120, $122,127-130$

- district of KOP 22, 33, 38

- inspectorate of KOP 34, 38

- Mokotów 46

- territory of AK 18

- St.:

- - Aleja Niepodległości 46, 109

- - Aleje Jerozolimskie 46

- - Aleja Szucha 86, 109-110, 112, 119

- - Belwederska 35

- - Chłodna 60

- - Chmielna 44

- - Kossaka 46, 87-88

- - Koszykowa 111, 119

- - Kozia 109, 113

- - Krakowskie Przedmieście 109

- - Kredytowa 102

- - Lwowska 110-111

- - Narbutta 46, 89, 116
- - Oleandrów 28, 33

- - Podchorążych 119

- - Polna 57, 62

- - Szara 25

- - Twarda 25

- - Wilcza 46

- - Wiśniowa 46, 109

- - Złota 89

- Żoliborz 86-87, 89

Warthegau 45

Wejherowo 77

Wiele 79-81

Wielkopolska (Greater Poland) 41, 58-59, 98

Włocławek (Leslau) 12, 60, 100, 122-125

- district of:

- - AK 125

- - KOP 122-123

Włodawa 16-17

Wólka Felińska 125

Wolsztyn 68

Wrocław 60, 130

Wygoń 82

Zajączkowo 77

Zalesie 51

Zambrów 72

Zwickau 124

Zwoleń 103, 116

Żerań 29

Żychlin 45 


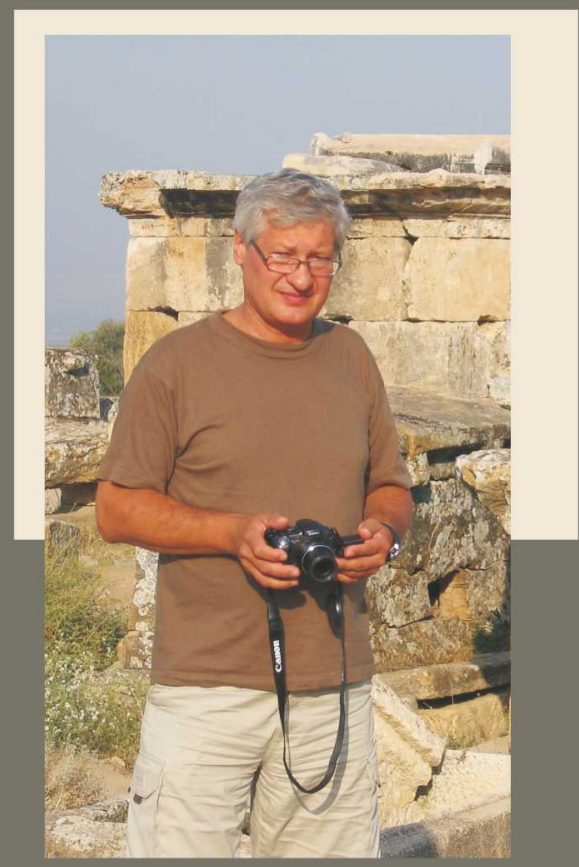

ANDRZEJ GĄSIOROWSKI (born in 1950), historian and political scientist. He graduated from the Faculty of Humanities of Gdańsk University in 1973, where he defended his PhD thesis in 1979. He received his post-doctoral degree at the Faculty of Historical Sciences of Nicolaus Copernicus University in Torun in 2000. He is an associate professor of Gdańsk University (2005); in 2010 he received the title of professor. In 2011 he became an ordinary professor of Gdańsk University. He was the head of the District Commissionfor the Examination of Crimes against the Polish Nationin the Institute of National Remembrance in Gdanisk. He is the head of the Scientific Board of the Baltic Institute in Gdańsk, a member of the Board of the Foundation of General Elżbieta Zawacka in Torun and a member of the Council for the Protection of Struggle and Martyrdom Sites in Gdańsk. $\mathrm{He}$ is also the author and co-author of a dozen of monographs and of over 200 scientific publications concerning the most recent history of Poland. At present he is the head of the Unit of International Relations in the Institute of Political Sciences at Gdańsk University, a professor in the Pomeranian College in Starogard Gdański, and a certified curator in the Stutthof Museum - the Branch in Sopot. He wrote the following scientific monographs: Szare Szeregi na Pomorzu Gdańskim w latach 1939-1945, Toruń 1997 [The Gray Ranks in Gdańsk Pomerania in the years 1939-1945]; Polska Armia Powstania. Największa tajemnica pomorskiej konspiracji, Torun 1998 [The Polish Army of Uprising: the biggest secret of the Polish underground movement]; Jan Kaszubowski i służby specjalne. Gestapo-Smiersz-UB...,Gdańsk 2008 [Jan Kaszubowski and special services: Gestapo-Smiersz-the Security Bureau...]. He is the co-author of the following scientific monographs: Wydział Marynarki Wojennej „Alfa" Komendy Głównej Armii Krajowej (along with B. Chrzanowski), Torun 2000 [The Branch of the Military Navy "Alfa" of the Main Headquarters of the Home Army]; Polska Podziemna na Pomorzu (1939-1945) (along with B. Chrzanowski and K. Steyer), Gdańsk 2005 [Undergound Poland in Pomerania (1939-1945)]; Tajna Organizacja Wojskowa "Gryf Pomorski" (along with K. Steyer), Gdańsk 2010 [The Secret Military Organization "Gryf Pomorski"]. The last book was awarded with the Stolema prize in Gdańsk in 2011.

The book constitutes a fulfillment of the promise given to General Elżbieta Zawacka, alias "Zo". It describes the underground activity of the Headquarters of the Defenders of Poland [KOP], the first - along with the Service for Poland's Victory - military organization which set up its structures in Gdańsk Pomerania as early as the autumn of 1939. The Headquarters of the Defenders of Poland was a well known organization at the beginning of the war as it conducted a vigorous information activity. The paper of the Headquarters of the Defenders of Poland „Polska Żyje!" was the most popular underground paper in occupied Poland in the years 1939-1940. The Pomeranian District of the Headquarters of the Defenders of Poland [KOP] was also involved in secret intelligence and charitable activities. Owing to the betrayal of the messenger operating between Warsaw and Toruń, the Gestapo managed to expose the structures of the organization in Pomerania and carry out its liquidation. The book shows not only the process of the investigation, but also the tragic fate of the heads of the Pomeranian District of KOP arrested in the autumn of 1940, both in the prison in Grudziądz and in the concentration camp in Stutthof, where they were sent in 1941. The book was based on a variety of sources: German documents, underground documents, accounts provided by members of KOP

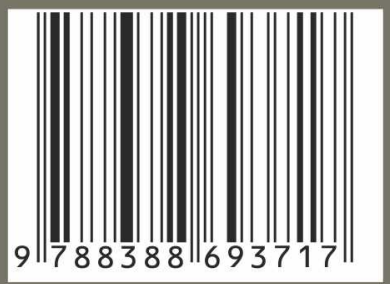
and postwar materials of the Security Bureau preserved in the Institute of National Remembrance. 